Portland State University

PDXScholar

Winter 3-4-2013

\title{
Large Woody Debris Mobility Areas in a Coastal Old- Growth Forest Stream, Oregon
}

Beth Marie Bambrick

Portland State University

Follow this and additional works at: https://pdxscholar.library.pdx.edu/open_access_etds

Part of the Geomorphology Commons

Let us know how access to this document benefits you.

\section{Recommended Citation}

Bambrick, Beth Marie, "Large Woody Debris Mobility Areas in a Coastal Old-Growth Forest Stream, Oregon" (2013). Dissertations and Theses. Paper 658.

https://doi.org/10.15760/etd.658

This Thesis is brought to you for free and open access. It has been accepted for inclusion in Dissertations and Theses by an authorized administrator of PDXScholar. Please contact us if we can make this document more accessible: pdxscholar@pdx.edu. 
Large Woody Debris Mobility Areas in a Coastal

Old-Growth Forest Stream, Oregon

\title{
by
}

Beth Marie Bambrick

A thesis submitted in partial fulfillment of the requirements for the degree of

\author{
Master of Science \\ in \\ Geography
}

\author{
Thesis Committee: \\ Martin Lafrenz, Chair \\ Keith Hadley \\ Jiunn-Der (Geoffrey) Duh \\ Portland State University \\ 2013
}


(C) 2013 Beth Marie Bambrick 


\begin{abstract}
This study uses a spatial model to visualize LWD mobility areas in an approximate $1 \mathrm{~km}$ reach of Cummins Creek, a fourth-order stream flowing through an old-growth Sitka spruce-western hemlock forest in the Oregon Coast Range. The model solves a LWD incipient motion equation for nine wood size combinations $(0.1 \mathrm{~m}, 0.4 \mathrm{~m}, 1.7 \mathrm{~m}$ diameters by $1.0 \mathrm{~m}, 6.87 \mathrm{~m}, 47.2 \mathrm{~m}$ lengths) during the 2-year, 10-year, and 100-year discharge events. Model input variables were derived from a combination of field survey, remotely sensed, and modeled data collected or derived between June 2010 and July 2011. LWD mobility map results indicate the 2-year discharge mobilizes all modeled diameters, but mobile piece lengths are shorter than the bankfull channel boundary. Mobility areas for each wood size combination increases with discharge; 10-year and 100-year discharge events mobilize wood longer than average bankfull width within a confined section of the main stem channel, and mobilize LWD shorter than bankfull width within the main stem channel, side channels, and floodplain. No discharge event mobilizes the largest LWD size combination (1.7m / 47.2). Recruitment process was recorded for all LWD during June 2010, revealing that all mobile wood in the study reach was shorter than bankfull width. Based on these conflicting results, I hypothesize the distribution of wood in Cummins Creek can be described in terms of discharge frequency and magnitude, instead of as a binary mobile/stable classification. Mobility maps
\end{abstract}


could be a useful tool for land managers using LWD as part of a stream restoration or conservation plan, but will require additional calibration. 


\section{TABLE OF CONTENTS}

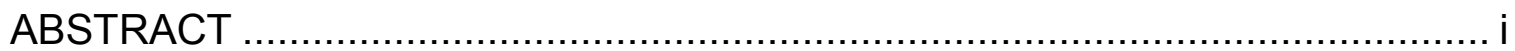

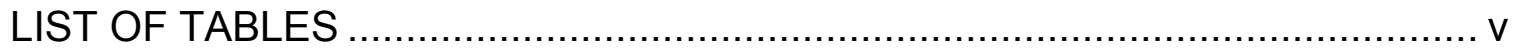

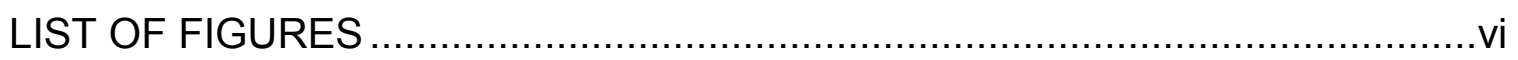

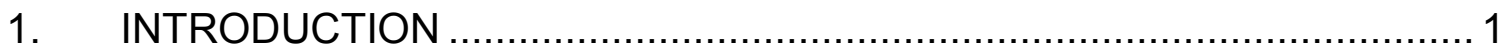

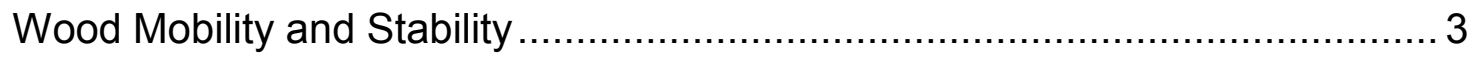

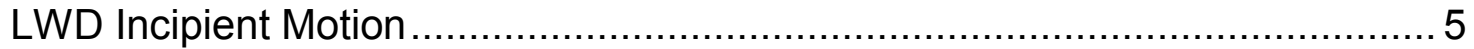

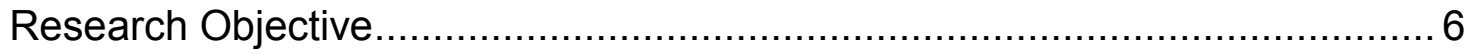

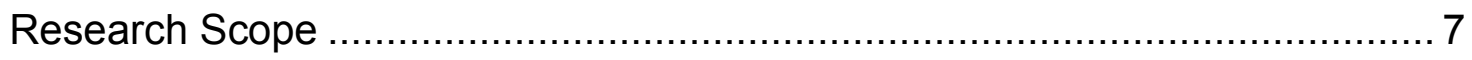

2. STUDY AREA: CUMMINS CREEK, OREGON $\ldots \ldots \ldots \ldots \ldots \ldots \ldots \ldots \ldots \ldots \ldots . \ldots$

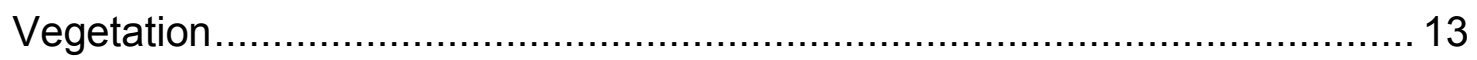

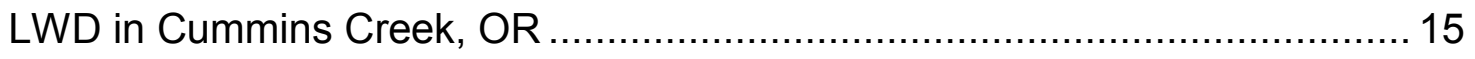

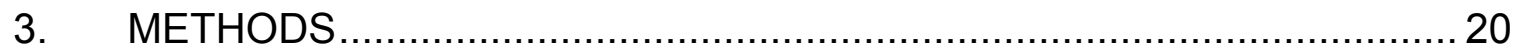

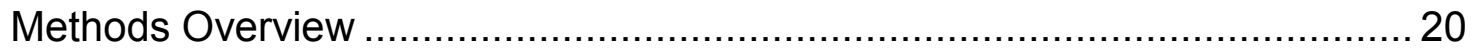

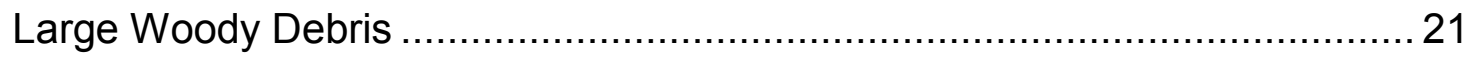

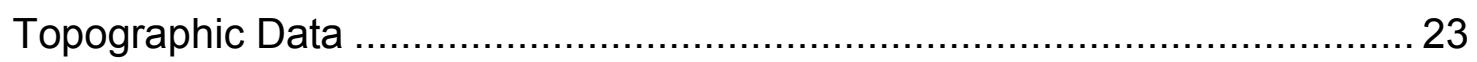

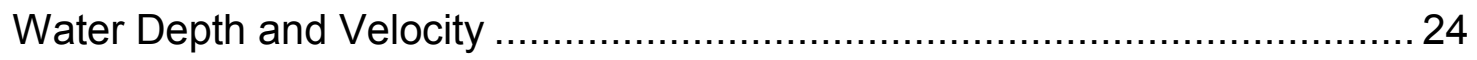

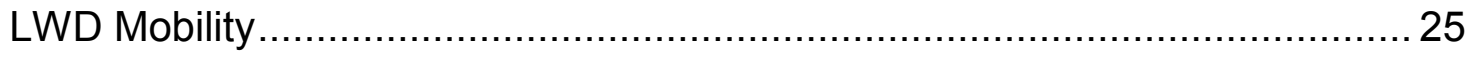

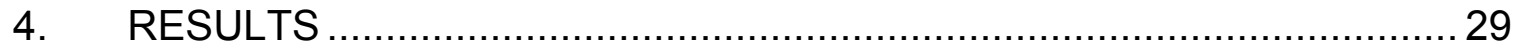

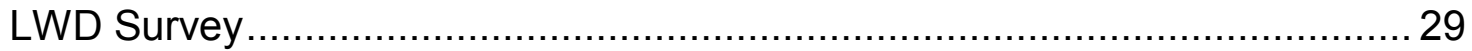

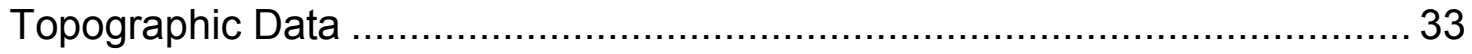

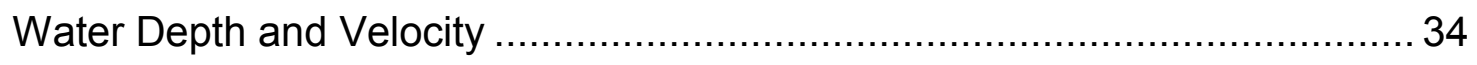

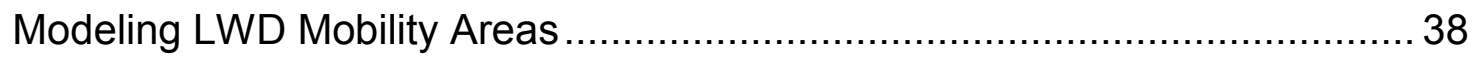




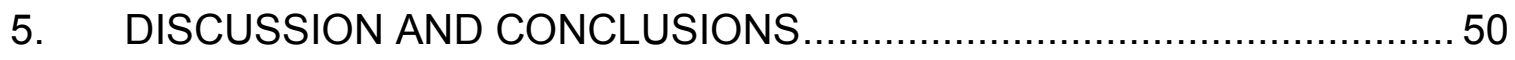

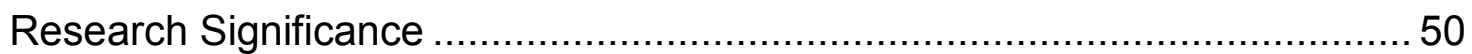

LWD Survey and Spatial Model Results .................................................. 51

Potential Use of Spatially-Explicit LWD Mobility Modeling ............................ 56

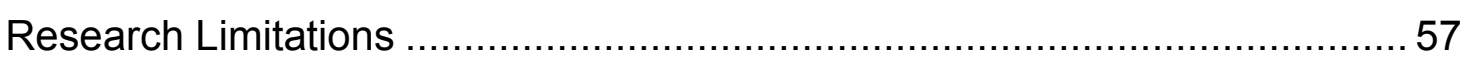

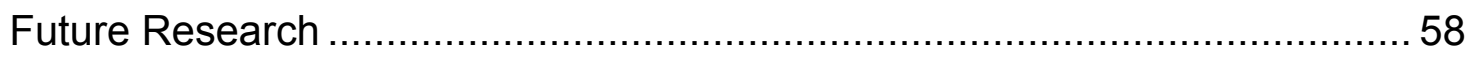

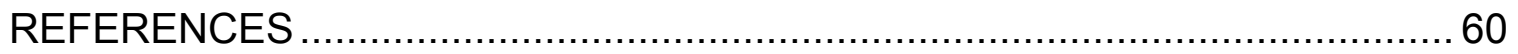

APPENDIX A: VARIABLE DERIVATION PROCESSES .................................66

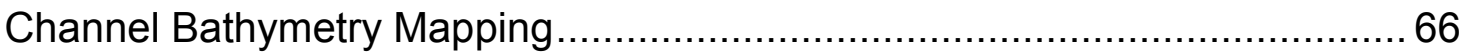

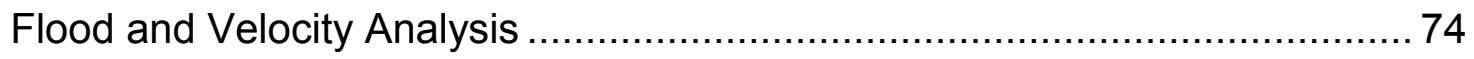

Appendix B: ArcGIS ModelBuilder Schematics ......................................... 77 


\section{LIST OF TABLES}

Table 2.1: Maximum age and sizes for species in Picea sitchensis-Tsuga heterophylla zone.

Table 3.1: Parameter values substituted in each of the variables and its source 21

Table 3.2: LWD diameter/length size combinations...................................... 22

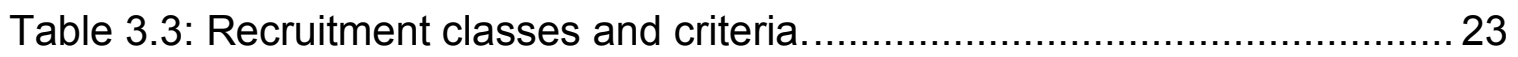

Table 3.4: Modeled peak-flow discharge values for various flood stages.......... 25

Table 4.1: Initial mobility areas by discrete values and percentage of total flood inundation area by LWD diameter and discharge magnitude.

Table 4.2: Final mobility areas by discrete values and percentage of flood inundation area by LWD diameter and discharge magnitude, grouped by LWD length.

Table 4.3: Probability of mobility for $0.1 \mathrm{~m} / 1.0 \mathrm{~m}$ length wood during any given year within the entire study reach.

Table 4.4: Probability of mobility for $0.1 \mathrm{~m} / 6.87 \mathrm{~m}$ length wood within the entire study reach.

Table 4.5: Probability of mobility for $0.1 \mathrm{~m} / 47.2 \mathrm{~m}$ length wood within the entire study reach.

Table 4.6: Probability of mobility for $0.4 \mathrm{~m} / 1.0 \mathrm{~m}$ length wood within the entire study reach.

Table 4.7: Probability of mobility for $0.4 \mathrm{~m} / 6.87 \mathrm{~m}$ length wood within the entire study reach

Table 4.8: Probability of mobility for $0.4 \mathrm{~m} / 47.2 \mathrm{~m}$ length wood within the entire study reach

Table 4.9: Probability of mobility for $1.7 \mathrm{~m} / 1.0 \mathrm{~m}$ length wood within the entire study reach.

Table 4.10: Probability of mobility for $1.7 \mathrm{~m} / 6.87 \mathrm{~m}$ length wood within the entire study reach 


\section{LIST OF FIGURES}

Figure 2.2: Monthly average temperature and precipitation at Honeyman State Park, OR.

Figure 2.3: Hillshade map of Cummins Creek study reach............................. 12

Figure 2.4: Hillslope failure in Cummins Creek drainage basin, illustrating the potential for the delivery of large volumes of LWD by debris flows.

Figure 2.5: Windsnapped tree positioned on the banks of Cummins Creek introducing LWD into the stream as partial or intact tree structures. 16

Figure 2.6: Log-jam in Cummins Creek.

Figure 2.7: Perched LWD perpendicularly $\sim 1 \mathrm{~m}$ above stream channel............ 18

Figure 2.8: Log-jams are indicative of fluvial wood transport........................... 19

Figure 4.1: LWD diameter frequency distribution. Vertical dotted lines indicate the range of sizes used in the GIS model, i.e., $0.1 \mathrm{~m}, 0.4 \mathrm{~m}$, and $1.7 \mathrm{~m}$.

Figure 4.2: LWD length frequency distribution. Vertical dotted lines indicate the range of sizes used in the GIS model, i.e., $1.0 \mathrm{~m}, 6.87 \mathrm{~m}$, and $47.2 \mathrm{~m}$.

Figure 4.3: Scatterplot of LWD individual piece sizes in Cummins Creek, OR. .. 30

Figure 4.4: Scatterplot representing LWD diameter and length pairs when grouped by mobility status in Cummins Creek, OR. .. 31Figure 4.5: LWD diameter and length distributions grouped by recruitment process.

Figure 4.6: Image 'A' represents the modified hillshade map of Cummins Creek study reach illustrating local topographic relief.

Figure 4.7: Slope map of Cummins Creek created from modified LiDAR-derived

DEM.

Figure 4.8: 2-year Water Depth Map at Cummins Creek, OR. …..................... 35

Figure 4.9: 10-year Water Depth Map at Cummins Creek, OR. ........................ 36

Figure 4.10: 100-year Water Depth Map at Cummins Creek, OR..................... 36

Figure 4.11: 2-year Water velocity map at Cummins Creek, OR...................... 36

Figure 4.12: 10-year Water velocity map at Cummins Creek, OR..................... 37 
Figure 4.13: 100-year Water velocity map at Cummins Creek, OR

Figure 4.14: LWD mobility map representing a 2-yr flood when only considering diameter. 39

Figure 4.15: LWD mobility map representing a 10-yr flood when only considering diameter. 39

Figure 4.16: LWD mobility map representing an 100-yr flood when only considering diameter. 40

Figure 4.17: LWD mobility map for $0.1 \mathrm{~m}$ diameter/1.0m length wood during a 2year, 10-year, and 100-year flood..

Figure 4.18: LWD mobility map for $0.1 \mathrm{~m}$ diameter $/ 6.87 \mathrm{~m}$ length wood during a 2year, 10-year, and 100-year flood...

Figure 4.19: LWD mobility map for $0.1 \mathrm{~m}$ diameter $/ 47.2 \mathrm{~m}$ length wood during a 2year, 10-year, and 100-year flood.

Figure 4.20: LWD mobility map for $0.4 \mathrm{~m}$ diameter $/ 1.0 \mathrm{~m}$ length wood during a 2 year, 10-year, and 100-year flood......

Figure 4.21: LWD mobility map for $0.4 \mathrm{~m}$ diameter $/ 6.87 \mathrm{~m}$ length wood during a 2year, 10-year, and 100-year flood...

Figure 4.22: LWD mobility map for $0.4 \mathrm{~m}$ diameter $/ 47.2 \mathrm{~m}$ length wood during a 2 year, 10-year, and 100-year flood.

Figure 4.23: LWD mobility map for $1.7 \mathrm{~m}$ diameter/1.0m length wood during a 2 year, 10-year, and 100-year flood.

Figure 4.24: LWD mobility map for $1.7 \mathrm{~m}$ diameter/6.87m length wood during a 2year, 10-year, and 100-year flood.

Figure 5.1: Individual LWD piece sizes with respect to the modeled size classes (black circles). 


\section{INTRODUCTION}

Large woody debris (LWD) - wood $\geq 10 \mathrm{~cm}$ in diameter and $\geq 1 \mathrm{~m}$ in length within the stream channel (Wohl et al., 2010) - is an ecologically important component of natural forest stream channels of the Pacific Northwest. LWD decreases water velocity and redirects flow (Abbe and Montgomery, 1996), alters channel form (Abbe and Montgomery, 2003), produces complex terrestrial successional pathways (Fetherston et al., 1995), and provides critical habitat to aquatic species (Montgomery et al., 1999). LWD is a dynamic stream component, whose abundance changes in response to disturbance processes that introduce wood and export wood from the stream channel such as wind, bank erosion, debris flows, fire, and flooding (e.g.,Bahuguna et al., 2010; Benda et al., 2005; Keller and Swanson, 1979; Lienkaemper and Swanson, 1987; Merten et al., 2010).

Little research has been done to model LWD mobility areas resulting from large flood events and its role in the dynamics in natural streams. Although considerable research has examined the mechanisms affecting wood volumes and its role on natural stream channels, attempts to create spatially-explicit wood mobility models for natural streams are rare. In this thesis I approach the problem of wood mobility by creating a GIS model to visualize wood mobility areas during the 2-year, 10-year, and 100-year discharge events based on the equation that describes instantaneous rotation of a right-angle cylinder (Bocchiola et al., 2006a). 
Process domains are one method used to conceptualize the spatial and temporal variability of disturbance regimes within a watershed (Montgomery, 1999). Disturbance processes are discrete events that shape ecological communities through "....chang[ing] resources, substrate availability, or the physical environment" (White and Pickett, 1985). Disturbance regimes are the statistical distributions of a disturbance process' frequency, magnitude, and duration. Process domains are areas within a watershed that when mapped, identify the spatial distribution of disturbance regimes (Montgomery, 1999).

An assumption of the process domain concept is that each process domain is associated with distinct ecological communities (Montgomery, 1999). LWD quantities and distributions at varied scales are caused by the spatial and temporal variability of disturbance processes, which input and deplete wood from the stream (Meleason, 2001). When considered from the process domain framework, wood distributions follow a predictable pattern based on disturbance regimes.

Small headwater streams flowing through steep hillslopes that are dominated by landslide disturbance events may experience large pulses of nonaggregated wood entering the stream that never move downstream (May and Gresswell, 2003). As headwater stream size and discharge increases, debris flows become the primary disturbance agent. Debris flows have the energy to entrain and mobilize LWD downstream (May and Gresswell, 2004), creating 
large LWD accumulations that can remain in place until subsequent debris flow events (Benda et al., 2005).

Fluvial and climatic disturbance processes dominate larger alluvial streams and drive LWD abundance. Whole trees are introduced to the stream through bank erosion or windthrow (Lienkaemper and Swanson, 1987), while portions of trees can enter the stream when trees are snapped by high winds (Bahuguna et al., 2010). Wood mobility caused by flooding is an important process that transfers wood downstream through and laterally outside of the stream channel (Hassan et al., 2005). As such, LWD represents a broad size range in floodplain stream channels, occurring as single pieces of wood; or as an accumulation of small LWD deposited on larger pieces during flood events, forming log-jams or wood rack structures (Abbe and Montgomery, 2003).

\section{Wood Mobility and Stability}

The stability of wood within log-jams defines its function in modifying stream channels. Stable wood (key-LWD) secures log-jams in position, while mobilized LWD are deposited and 'racked' upon key-LWD. The quantities and distribution of mobile and stable LWD determine the types of log-jams that will occur within a reach, which have varying effectiveness in altering channel form (Abbe and Montgomery, 2003). The different types of channel morphology created by log-jams affect the dynamics between riverine and terrestrial systems (Collins et al., 2012). 
Mobile LWD is most often defined as wood shorter than bankfull channel width (Gurnell et al., 2002). This definition, based on field observations (Lienkaemper and Swanson, 1987; Nakamura and Swanson, 1994), has been used in to classify stable and mobile wood in stream surveys (Seo and Nakamura, 2010). Mobile LWD is often incorporated into wood budgeting equations and models that predict wood volumes in a specific reach over time, both of which are useful for conservation and restoration efforts (Beechie et al., 2000; Benda et al., 2007; Benda et al., 2003; Curran, 2010; Meleason et al., 2003).

Wood stability and mobility classifications are relative measures of wood transport when the disturbance history for a specific reach or study area is unknown. LWD pieces recently recruited to a stream are more mobile than pieces that have been in the channel for some time (Keim et al., 2000). The amount and size of material moved by water increases with discharge (Hjulstrom, 1935; Leopold and Maddock, 1953); stable LWD may become mobile during increasingly high discharge floods (e.g., 2-year vs. 10-year or 100-year events). Wood mobility has been observed in natural streams during large magnitude flood events (Berg et al., 1998; Lienkaemper and Swanson, 1987) but the relationship between LWD size, discharge, and mobility in natural streams is poorly understood. Given the dearth of research deriving the direct relationship between LWD size and discharge with respect to LWD mobility, classifications of 
individual pieces of wood as mobile or stable based on piece size are inappropriate without site-specific knowledge of flood disturbance history.

\section{LWD Incipient Motion}

In its simplest form, estimates of incipient motion of a cylinder (e.g., LWD) occurs when the downslope forces of gravity and drag equal the upslope frictional force (Braudrick and Grant, 2000). This equation takes a different form if the body in motion is rolling or sliding along the stream bed. The Bocchiola et al. (2006) equation describes LWD movement as the instantaneous rotation of a right-angle cylinder, and is written in its general form as:

$$
Y_{R}=\frac{\rho_{w} d_{w}}{\rho_{\log } D_{\log }}=\frac{1}{1+C_{a} X_{R}}
$$

Where $\rho_{w}$ is water density, $d_{w}$ is water depth, $\rho_{\text {log }}$ is LWD density, $D_{\text {log }}$ is LWD diameter, and $C_{a}$ is the drag coefficient. $X_{R}$ is expressed as:

$$
X_{R}=\frac{1}{2} \frac{U^{2}}{g D_{\log } \cos \alpha \tan \delta-\sin \alpha}
$$

where $g$ is standard gravity, $\alpha$ is the channel slope, and $\delta$ is the critical bed slope at which LWD will begin to roll under dry conditions. Bocchiola et al. (2006) created a final incipient motion equation (3) that better fit the observed flume experiment results than the general incipient motion equation (1) because it 
accounts for differences in upstream and downstream water depth relative to a piece of LWD. Equation (3) takes a modified form of the force-balance equation including the introduction of power law coefficients $a_{R}$ and $b_{R}$; the two enu ıal signs indicate that incipient motion occurs when all sides of the equation are equal to each other.

$$
Y_{R}=a_{R}{\frac{\rho_{w} d_{w}}{\rho_{\log } D_{l o g}}}^{1+b_{R}}=\frac{1}{1+1.41 X_{R}}
$$

One application of this equation is to predict LWD mobility in natural streams by solving the mobility equation for various flow values (Bocchiola et al., 2006a). This approach is difficult to solve at the reach scale as the incipient motion equation would have to be solved a near infinite number of times to capture the variability of LWD size, water depth, velocity, and topography present in a natural stream channel.

\section{Research Objective}

The aim of my research is to establish a method to visualize LWD mobility areas as they relate to LWD size and stream discharge. I solve the equation (3) developed by Bocchiola et al. (2006a) using a raster (grid-based) GIS data model. This technique allows for the mobility equation to be solved at the pixel level within stream reach rather than for an entire reach and is only limited by the resolution of the input layers and amount of computer storage. This allowed me to create maps of LWD mobility areas for nine LWD size classes and three flood 
discharge values. These visualizations, in combination with results from a LWD survey, were then used to answer the following questions:

1. What sizes of wood are mobilized during 2-year, 10-year, and 100-year flood discharge events?

2. For mobile sizes of LWD, how much mobility area occurs and where is it located during 2-year, 10-year, and 100-year flood discharge events?

3. What is the probability of wood mobility during 2-year, 10-year, and 100year flood discharge events?

The objective of my research is to: 1) create new hypotheses about LWD mobility as it relates to wood size and discharge, and 2) identify possible inconsistencies between modeled and field-measured results.

\section{Research Scope}

My research focuses on Pacific Northwest stream systems located within the Picea sitchensis - Tsuga heterophylla (Sitka spruce - western hemlock) forest zone, bordering the Pacific Ocean (Franklin and Dyrness, 1988). Intense, historic timber harvesting has left few old-growth, coastal forests in this zone (Kennedy and Spies, 2004; Ohmann et al., 2007) leading to present efforts to conserve and restore streams connected to the Pacific Ocean (Naiman et al., 2000). Earlier research indicates a landscape scale connection between inland and adjacent coastal ecosystems (Spies et al., 2002). These works and others concerning the rarity, conservation and restoration, and connection with inland 
ecosystems provide the context and define the scope of my research to westslope alluvial streams on the west side of the Oregon Coast Range. 


\section{STUDY AREA: CUMMINS CREEK, OREGON}

My study site is the lower reach of Cummins Creek, located along

Oregon's central coast $\left(44^{\circ} 15^{\prime} \mathrm{N}, 124^{\circ} 02^{\prime} \mathrm{W}\right.$, Figure 2.1) within the Cummins Creek Wilderness Area (designated by congress in 1983). Wimberly and Spies (2001) describe the area as minimally logged before 1983 (Fig 2.1) and the wilderness designation in 1983 prevents any future timber harvesting activities or use of machinery within the wilderness boundary.

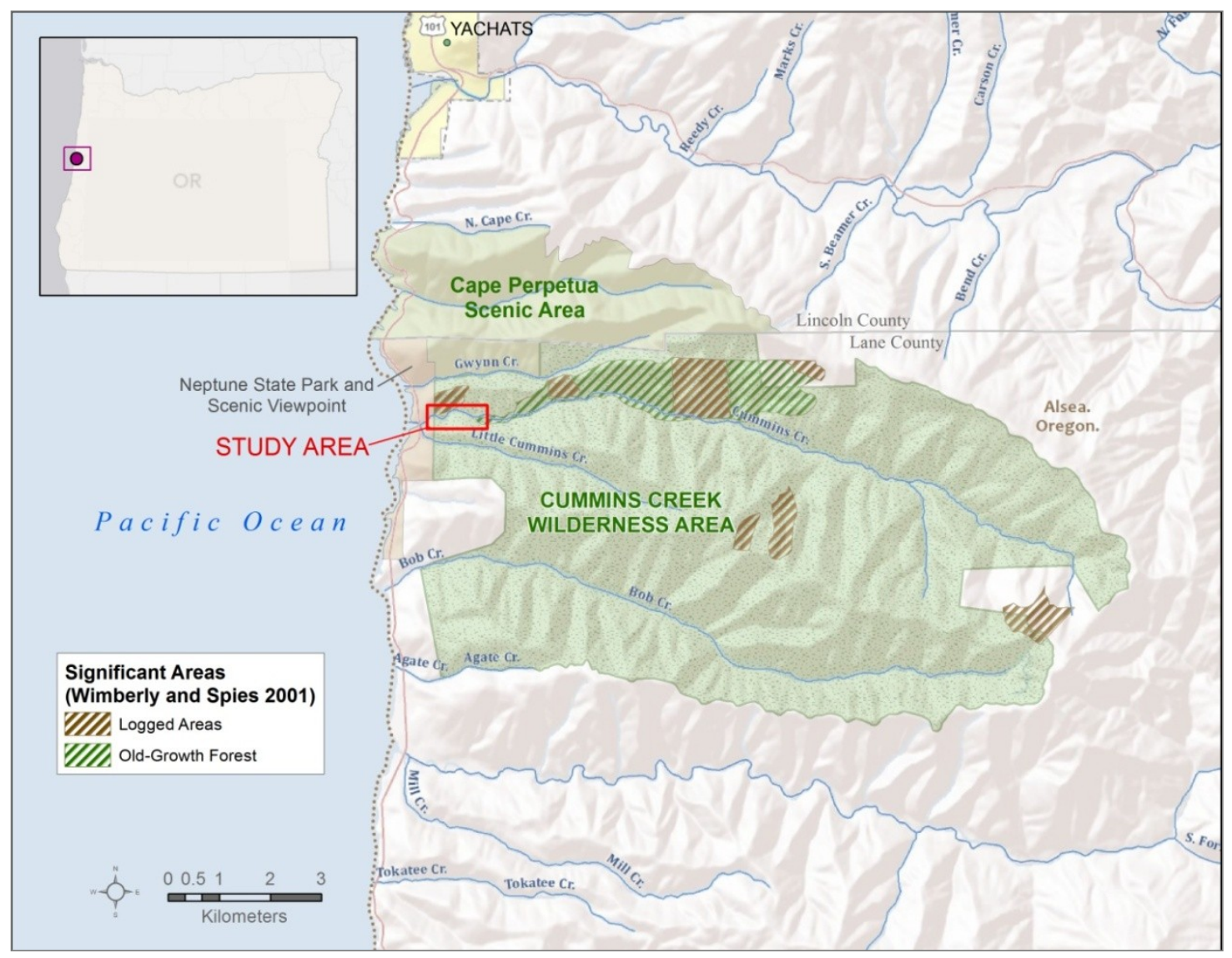

Figure 2.1: Location map of Cummins Creek study area (ESRI, 2009; ESRI, 2011; Lehner et al., 2008; TomTom et al., 2011) 
The climate at Cummins Creek is typical of maritime locations on the northern Pacific Ocean, characterized by mild summers and cool, wet winters. Monthly temperature is moderated by humid, off-shore air. The nearest weather station to Cummins Creek is located at Honeyman State Park ( $43^{\circ} 55^{\prime} 47^{\prime \prime} \mathrm{N}, 124^{\circ}$ 06'24" W; elev.: 35 m), near Florence, OR (WRCC 2012). Weather records from $1971-2012$ exhibit that average maximum yearly temperature is $15.4^{\circ} \mathrm{C}\left(59.8^{\circ} \mathrm{F}\right)$, while average minimum yearly temperature is $6.4^{\circ} \mathrm{C}\left(43.6^{\circ} \mathrm{F}\right)$. The humid air masses that regulate temperature also bring much precipitation to the region. Average yearly precipitation at the Honeyman State Park weather station is $176.22 \mathrm{~cm}$ (69.38 in). The majority of this precipitation falls as rain; the average yearly snowfall is $1.78 \mathrm{~cm}$ (WRCC 2012) (Figure 2.2).

The warmest monthly temperatures and lowest precipitation occurs in summer, while the coolest monthly temperatures and highest precipitation occurs during fall and winter. Strong windstorms are common along the Oregon coast during the winter with wind speeds exceeding hurricane $(\geq 74 \mathrm{mph})$ velocities (Knapp and Hadley, 2012; Read, 2008). 


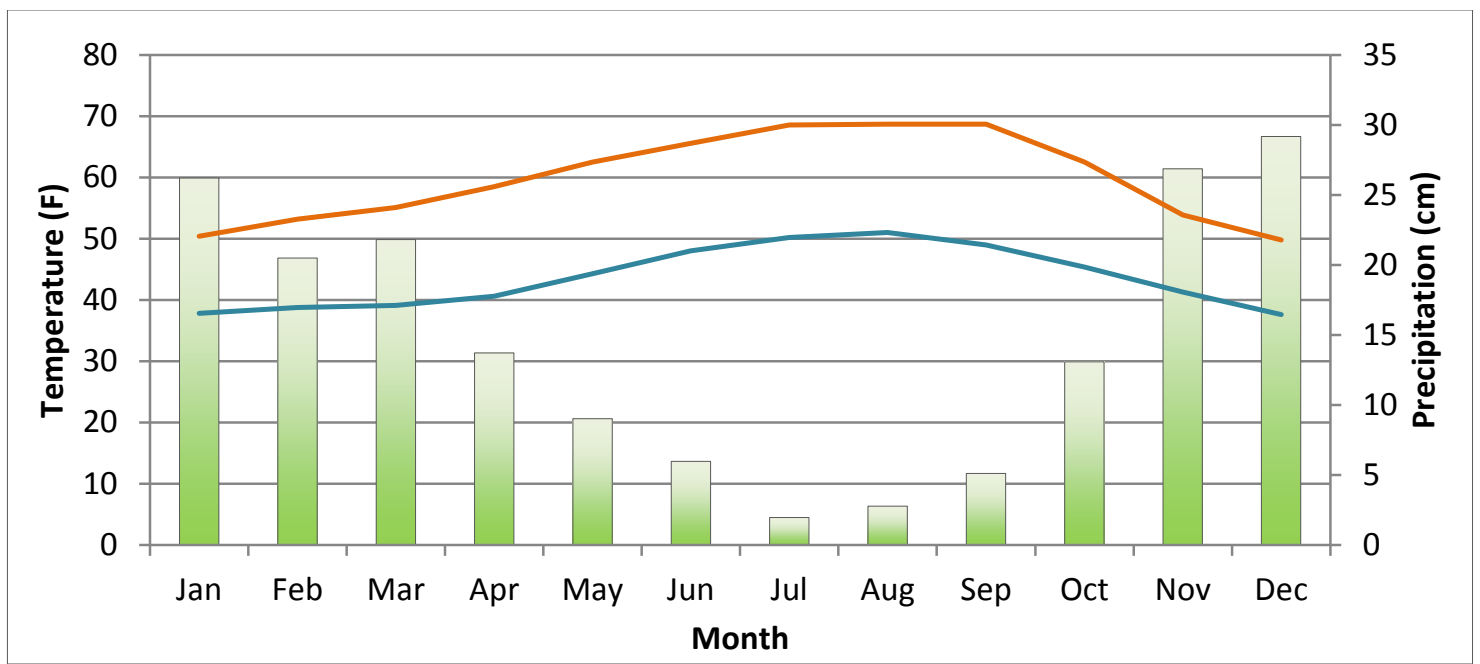

Figure 2.2: Monthly average temperature and precipitation at Honeyman State Park, OR (WRCC 2012). The orange line represents average high temperature, the blue line represents the average low temperature, and green bars represent average monthly precipitation.

The Cummins Creek watershed is an approximately $21.5 \mathrm{~km}^{2}$ oval-shaped basin, with elevations ranging from sea level to over $800 \mathrm{~m}$ at its highest point. Cummins creek is an alluvial/bedrock stream that empties directly into the Pacific Ocean (Figure 2.3). Side channels are common in the narrow floodplain adjacent to steep hillslopes. Summer baseflow was directly measured as 0.45 $\mathrm{m}^{3} \mathrm{~s}^{-1}(15.75 \mathrm{cfs})$ in the study reach during July 2011 , and the 2-year discharge is $17.58 \mathrm{~m}^{3} \mathrm{~s}^{-1}(621 \mathrm{cfs})$ as modeled by StreamStats (U.S. Geological Survey 2011).

The average bankfull channel width at the survey cross-sections is $18.4 \mathrm{~m}$. Stream bedload is typified by boulder and cobble-sized sediment. Bedload is absent in some reaches of Cummins Creek resulting in the incision of the underlying bedrock. The last known large floods in the area were $+100-y r$ floods during 1996 and 1998, and a 50-yr flood during 1973 (Wimberly and Spies, 2001). Heavy winter precipitation that causes flooding also leads to frequent 
debris flows on the steep slopes in the Oregon Coast Range (May and Gresswell, 2004), and Cummins Creek shows evidence of several debris flows affecting the slopes near the study reach (Figure 2.4).

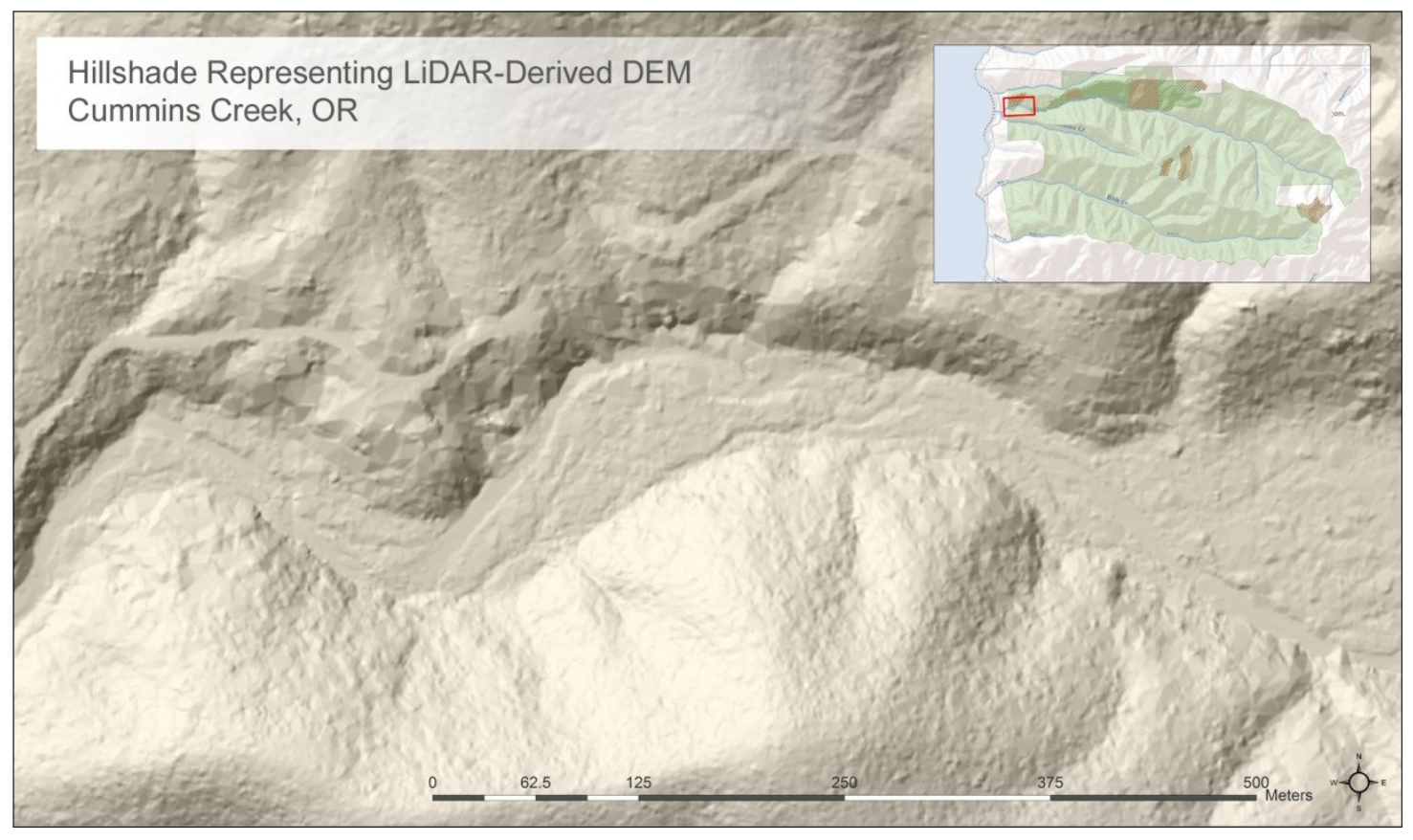

Figure 2.3: Hillshade map of Cummins Creek study reach. 


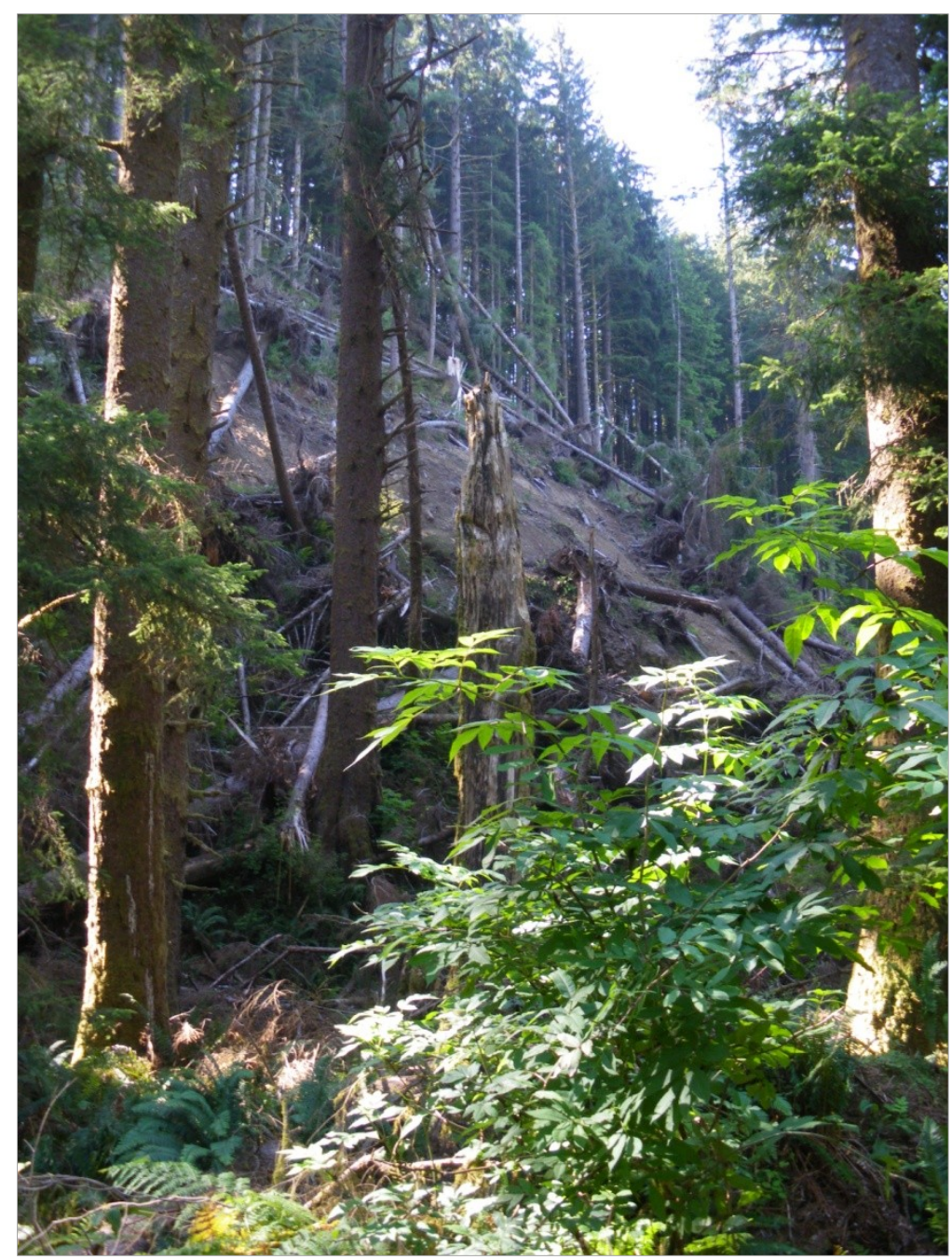

Figure 2.4: Hillslope failure in Cummins Creek drainage basin, illustrating the potential for the delivery of large volumes of LWD by debris flows.

\section{Vegetation}

Cummins Creek is typical of old-growth coastal forests in Oregon.

Cummins Creek is located in the Picea sitchensis zone that spans from northern

California to southern Alaska. (Franklin and Dyrness 1988). Within this range, Picea sitchensis extends a few kilometers inland and generally $<10 \mathrm{~km}$ up river 
valleys. This zone is typically found below $150 \mathrm{~m}$ elevation, but can reach elevations of $600 \mathrm{~m}$ when tall coastal mountain ranges are close to the shoreline. The predominant tree species found in this zone are Sitka spruce (Picea sitchensis), western hemlock (Tsuga heterophylla), western red cedar (Thuja plicata), and Douglas-fir (Pseudotsuga menziesii). Grand fir (Abies grandis) is present but less abundant, while red alder (Alnus rubra), black cottonwood (Populus trichocarpa), and big-leaf maple (Acer macrophyllum) are common in riparian areas. Tree species distribution varies with respect to its proximity to the stream and location within the watershed. Douglas-fir are more likely to be found on hillslopes and near headwater streams, while the dominant conifer species, Sitka spruce, and hardwood species such as red alder are more prevalent in the riparian valley (Pabst and Spies 1999, Wimberly and Spies 2001). Sitka spruce is limited to the area covered by the narrow fog belt occurring near the shoreline (Franklin and Dyrness 1988). Sitka spruce can live up to $700-800$ years in an undisturbed forest. They can attain diameters over $3 \mathrm{~m}(9.84 \mathrm{ft})$ and heights over $40 \mathrm{~m}$ (131.23 ft) (USDA 1990). Typical age, height, and diameter ranges of other species found in the Cummins Creek watershed are listed in Table 2.1.

The Cummins Creek Wilderness area experienced a series of fires during the mid-1800s and early-1900s, with the last stand replacing fire occurring in 1849 (Morris 1934, Impara 1997, Wimberly and Spies 2001). This fire may have limited Sitka spruce ages at Cummins Creek to between 200-250 years old 
although some Sitka spruce in the riparian zone were found to be over 500 years old (Hadley and Knapp in review).

Table 2.1: Maximum age and sizes for species in Picea sitchensis-Tsuga heterophylla zone (Franklin and Dyrness, 1988).

\begin{tabular}{llll}
\hline Species & Age (yrs) & Height (m) & Diameter (cm) \\
\hline $\begin{array}{l}\text { Sitka spruce } \\
\text { (Picea sitchensis) }\end{array}$ & $800+$ & $70-75$ & $180-230$ \\
$\begin{array}{l}\text { Douglas-fir } \\
\text { (Pseudotsuga Menziesii) }\end{array}$ & $750+$ & $70-80$ & $150-220$ \\
$\begin{array}{l}\text { Western hemlock } \\
\text { (Tsuga heterophylla) }\end{array}$ & $400+$ & $60+$ & $90-120$ \\
$\begin{array}{l}\text { Western red cedar } \\
\text { (Thuja plicata) }\end{array}$ & $1000+$ & $60+$ & $150-300$ \\
$\begin{array}{l}\text { Grand fir } \\
\text { (Abies grandis) }\end{array}$ & $300+$ & $40-60$ & $75-125$ \\
$\begin{array}{l}\text { Red alder } \\
\text { (Alnus rubra) }\end{array}$ & 100 & $30-40$ & $55-75$ \\
$\begin{array}{l}\text { Big-leaf maple } \\
\text { (Acer macrophyllum) }\end{array}$ & $300+$ & 15 & 50 \\
$\begin{array}{l}\text { Black Cottonwood } \\
\text { (Populus trichocarpa) }\end{array}$ & $200+$ & $25-35$ & $75-90$ \\
\hline
\end{tabular}

\section{LWD in Cummins Creek, OR}

The forest structure at Cummins Creek is continually changing in response to natural disturbance processes. These disturbance processes include windfall, windsnap, heart rot, debris flows, bank erosion, and rare fire events that introduce LWD into Cummins Creek (Figures 2.5 and 2.6). 
Combined, these processes have the potential to introduce high volumes of wood into the stream channel.

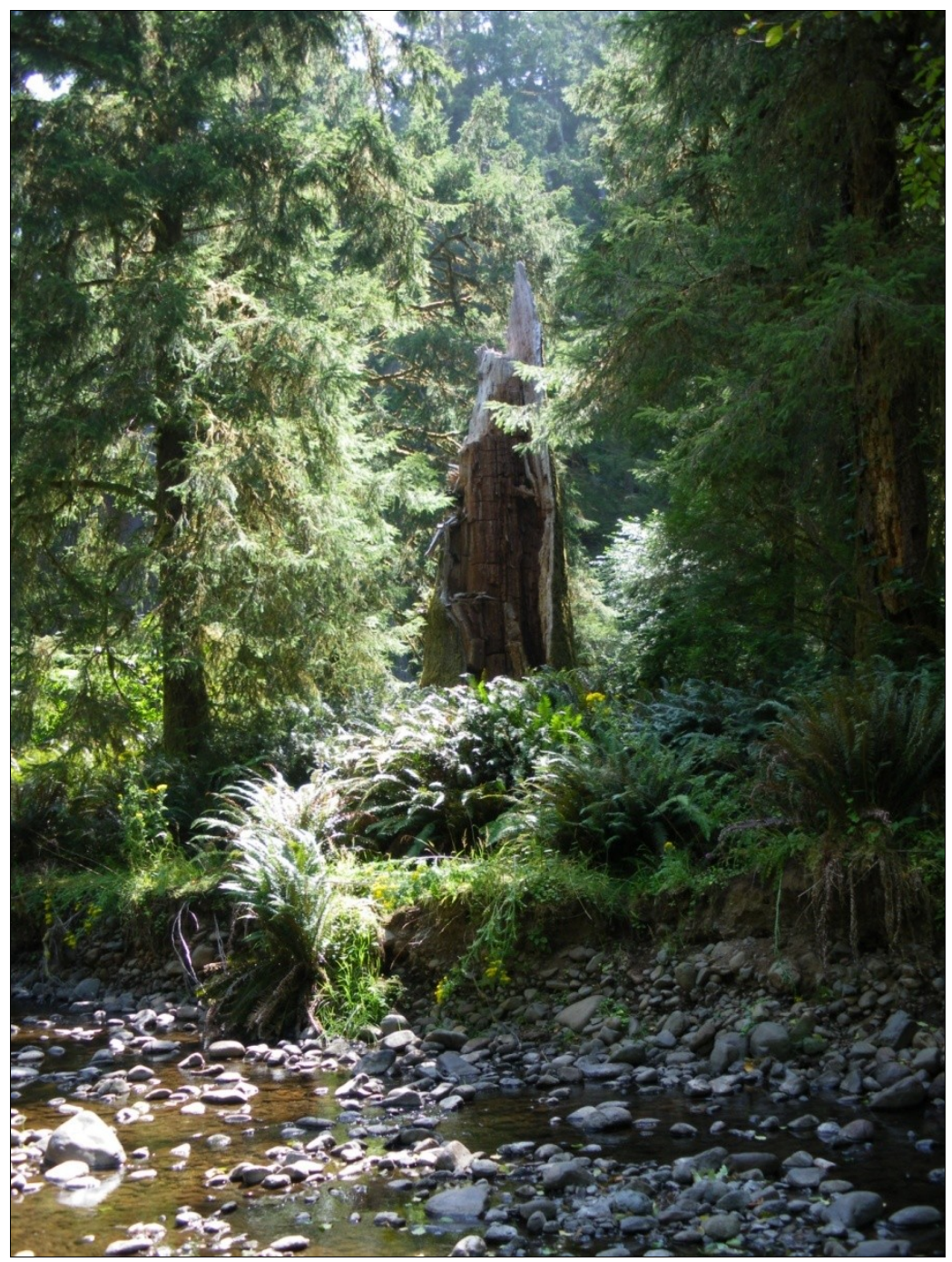

Figure 2.5: Windsnapped tree positioned on the banks of Cummins Creek introducing LWD into the stream as partial or intact tree structures. 

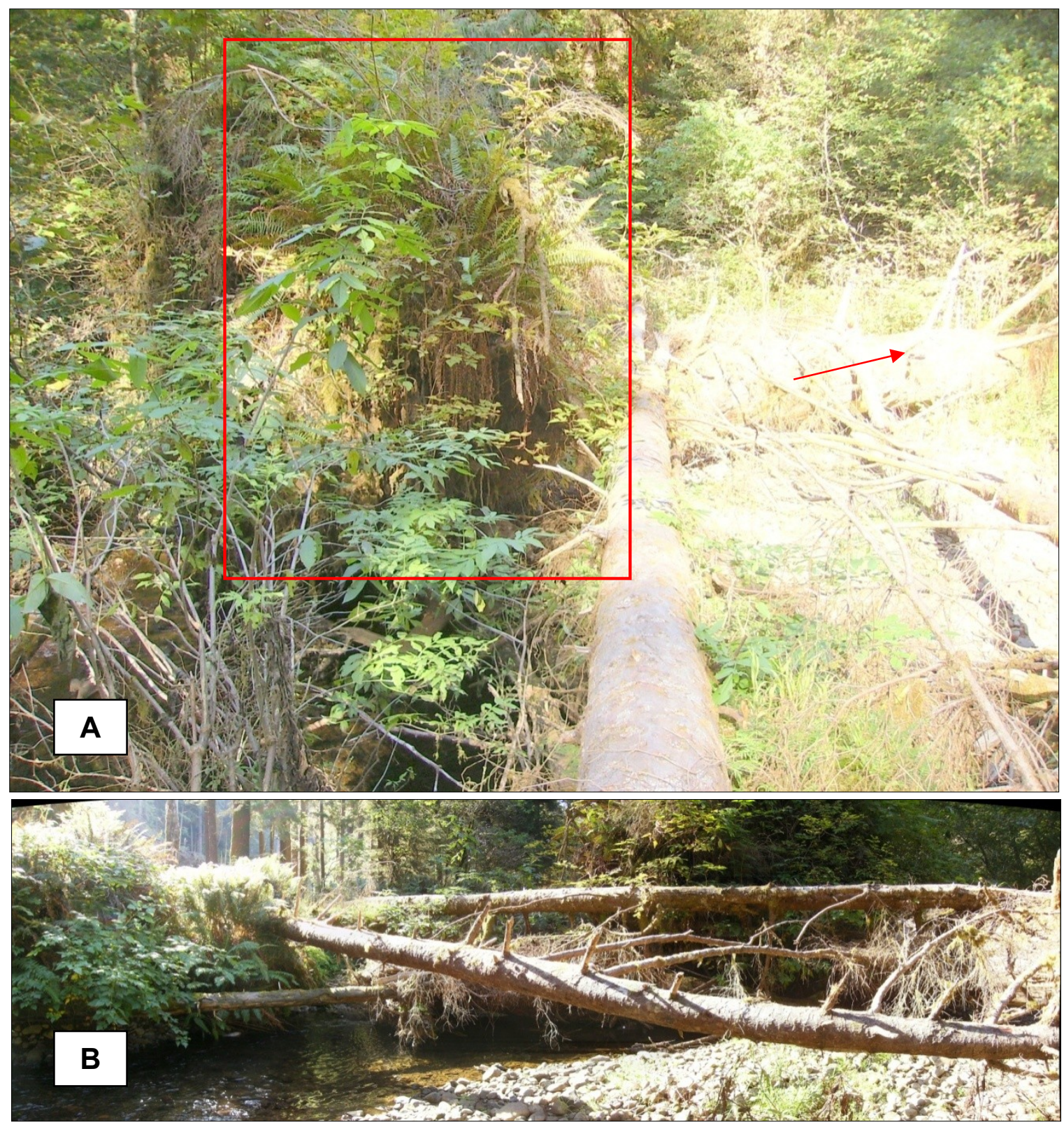

Figure 2.6: Log-jam in Cummins Creek. The red box in photo ' $A$ ' is enclosing a large root ball of a tree that continues towards the upper-right portion of the picture as indicated by the red arrow. LWD spanning photo ' $\mathrm{B}$ ' are upper portions of floodplain trees snapped off the base. 
The same winter storms that bring high winds also bring heavy rains that increase stream discharge and LWD mobility. Visual evidence at Cummins Creek of LWD mobility is common throughout the study reach (Figures 2.7 and 2.8).

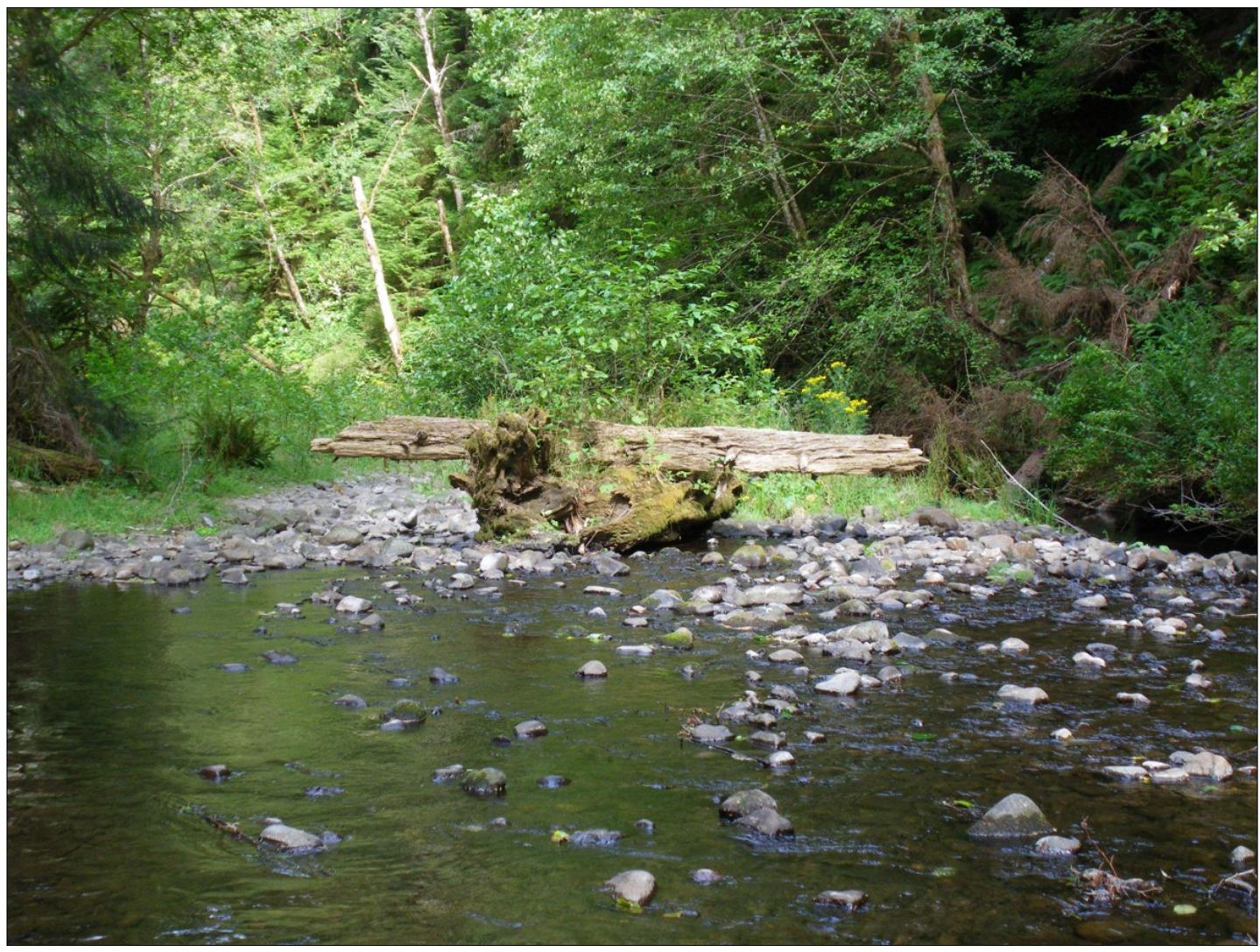

Figure 2.7: Perched LWD perpendicularly $\sim 1 \mathrm{~m}$ above stream channel. There are no nearby trees or snags near this LWD accumulation, indicating the stream transported the perched piece of wood to its current location during a flood event. 

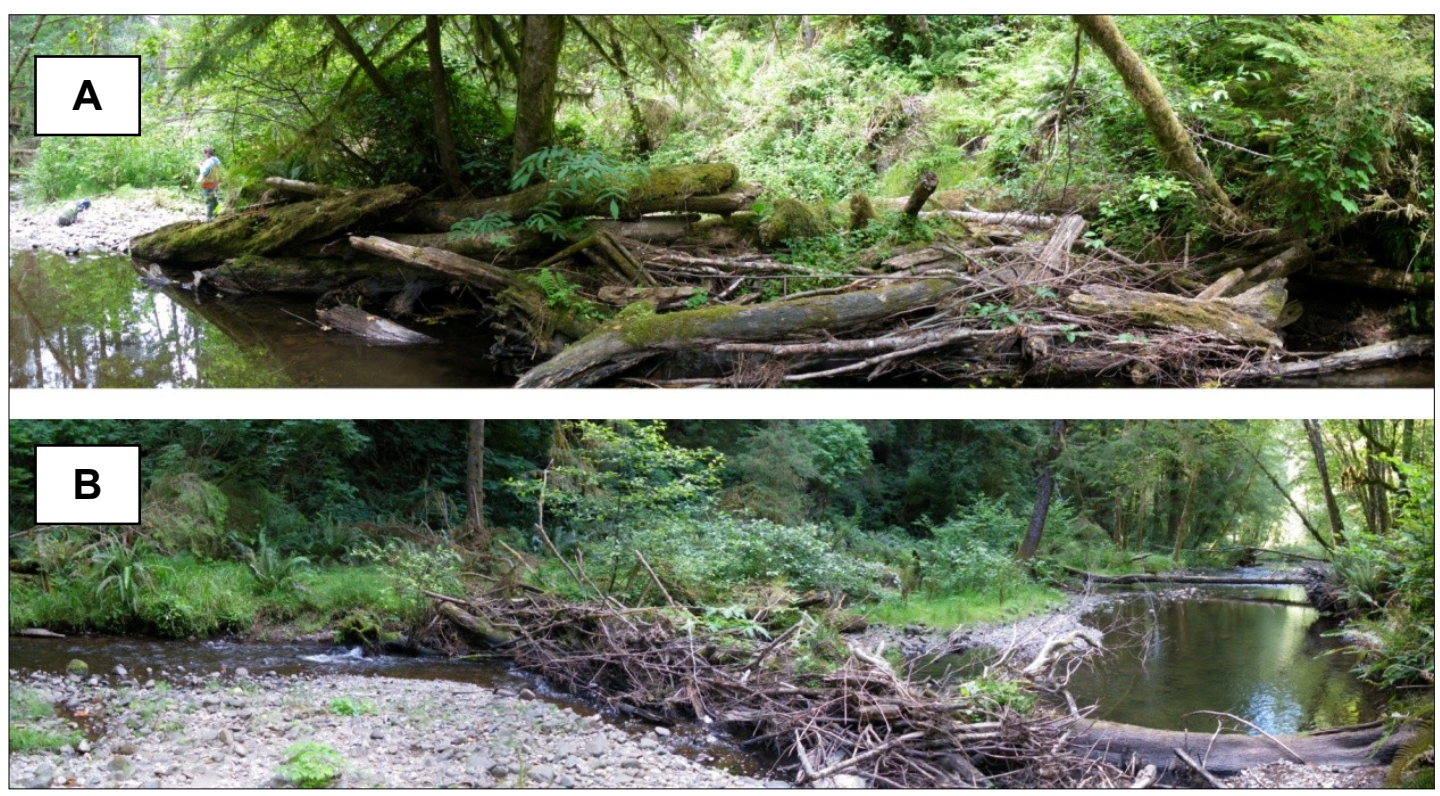

Figure 2.8: Log-jams are indicative of fluvial wood transport. These log-jams at Cummins Creek are comprised of small pieces of wood racked against a large, key piece of wood. Note in photo ' $B$ ', the lack of LWD upstream and downstream of the log-jam (left to right). 


\section{METHODS}

\section{Methods Overview}

My methods consisted of the three stages: 1) data acquisition, 2) model design, and 3) GIS modeling of incipient motion. I generated data for my model by:

1. Creating single-value raster layers to represent the remaining equation variables based on previously published values and known constants (Table 3.1).

2. Characterizing LWD found in Cummins Creek based on size and recruitment process, thus generating the LWD input size values $\left(D_{\text {wood, }}\right.$ $L_{\text {wood) }}$ for the GIS model (Table 3.2).

3. Modifying a lidar-derived DEM to represent stream bathymetry and derived channel slope data $(\alpha)$ from the modified DEM using GIS tools.

4. Performing a flood analysis for three discharge events (Table 3.4) in the study reach to generate the water depth $\left(D_{\text {water }}\right)$ and velocity $(U)$ data needed for modeling. 
Table 3.1: Parameter values substituted in each of the variables and its source

\begin{tabular}{ccc}
\hline Variable & Value & Source \\
\hline$\rho_{w}$ & $1000 \mathrm{~kg} / \mathrm{m}^{3}$ & constant value \\
$\rho_{\text {log }}$ & $700 \mathrm{~kg} / \mathrm{m}^{3}$ & Curran (2010) \\
$C_{a}$ & 1.41 & Bocchiola et al. (2006) \\
$g$ & $9.80665 \mathrm{~m} / \mathrm{s}^{2}$ & constant value \\
$\delta$ & $11^{\circ}$ & Bocchiola et al. (2006) \\
$a_{R}$ & 0.84 & Bocchiola et al. (2006) \\
$b_{R}$ & -0.77 & Bocchiola et al. (2006) \\
\hline
\end{tabular}

\section{Large Woody Debris}

\section{LWD Survey}

I conducted a LWD survey in June 2010 within my study reach defined by upstream and downstream cross-sections (Appendix, Figure A.1). The boundary locations were selected so that that the study reach represented a typical section of the stream where LWD was present throughout the reach. During my wood survey I recorded the diameter, length, and probable recruitment process for each piece of wood that met the minimum LWD size criteria $(\geq 0.1 \mathrm{~m}$ diameter and $1.0 \mathrm{~m}$ length). I calculated the minimum, logarithmic midpoint (average), and maximum diameter and length values to generate the LWD size input value 
combinations (Table 3.2). The wood recruitment process denotes how a piece of wood was recruited to its location in the stream at the time of the LWD survey in June 2010 (Table 3.3).

Table 3.2: LWD diameter/length size combinations. The model was run for 3 diameter classes and three length classes, for a total of 9 diameter/length combination size classes.

\section{LWD Diameter}

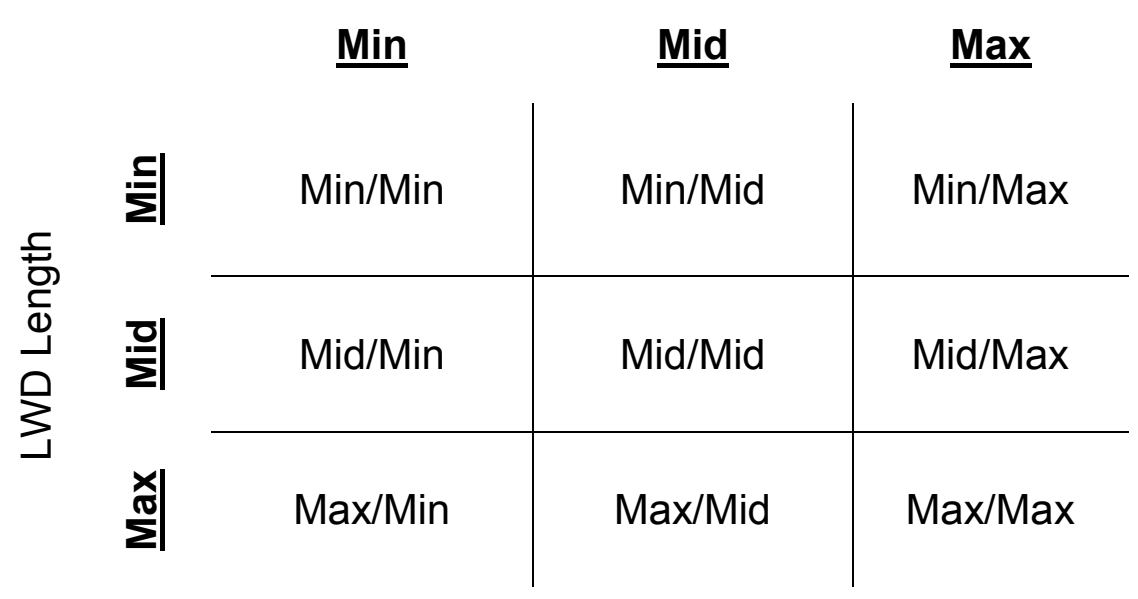


Table 3.3: Recruitment classes and criteria (Adapted from May and Gresswell, 2003 and Reeves et al., 2003).

\begin{tabular}{c|ll}
\hline $\begin{array}{c}\text { Mobility } \\
\text { Status }\end{array}$ & $\begin{array}{l}\text { Recruitment } \\
\text { Process }\end{array}$ & Classifying criteria \\
\hline Mobile & Fluvial Redistribution & $\begin{array}{l}\text { Pieces of wood that do not have attached root- } \\
\text { wads. Pieces can be broken and may be absent of } \\
\text { bark. Pieces may appear alone, but are generally } \\
\text { found as part of log-jams and can occur at some } \\
\text { distance above the stream channel. }\end{array}$ \\
\hline Stable & Wind & $\begin{array}{l}\text { Can be considered windsnapped or windthrown } \\
\text { trees. Windsnapped trees are broken boles from } \\
\text { standing live and dead trees. Windthrown trees are } \\
\text { single, uprooted tree or numerous uprooted trees in } \\
\text { a larger windthrow patch, often located further } \\
\text { upslope and knocking down trees growing closer to } \\
\text { the channel. } \\
\text { Localized bank failure and erosion occurring with } \\
\text { undercut trees rooted in the channel bank. } \\
\text { Bole extended into the local forest; however, no } \\
\text { physical recruitment process can be identified and } \\
\text { assumes biological causes of tree mortality. }\end{array}$ \\
\hline Individual \\
mortality/Treefall
\end{tabular}

\section{Topographic Data}

Elevation data representing the stream channel dimensions and slope for the study reach were generated from LiDAR-derived DEM data. Standard LiDAR data are generated by lasers emitting near infrared (NIR) wavelength pulses, reflected by solids but absorbed by water. One of the limitations of LiDARderived DEMs is that stream channel data represents water surface elevations and not true channel bathymetry elevations (Gessese et al., 2011), which limits its utility for modeling in-stream processes, including LWD mobility. Although 
there are LiDAR data generated by lasers emitting blue-green wavelength pulses which specifically collect stream bathymetry data (Hilldale and Raff, 2008), this technology is expensive and not widely available. This problem was circumvented by creating a modified DEM combing the LiDAR-derived DEM with an interpolated 2-D stream channel developed from the channel survey data (Merwade et al., 2008) (Appendix A).

\section{Water Depth and Velocity}

HEC-RAS v.4.1 (USACE 2010) and HEC-GeoRAS module v.4.3 for ArcGIS v.9.3.1 (USACE 2011) are software originally designed to delineate the 100 -year floodplain but can be used to model the spatial extent of other magnitude flood events (Chang et al., 2010). HEC-RAS is a one dimensional model that estimates water depths and velocities at individual cross-sections for discrete discharge values. HEC-GeoRAS expands the 1D flood model to a 2D georeferenced surface. The specific model parameters used to determine water depth as a function of velocity are discussed in the appendix. 
Table 3.4: Modeled peak-flow discharge values for various flood stages (U.S. Geological Survey 2011). Baseflow discharge observed during July 2011.

\begin{tabular}{cccc}
\hline Flood Stage & Peak Flow $\left(\mathbf{m}^{3} \mathbf{s}^{-1}\right)$ & Peak Flow (cfs) & $\begin{array}{c}\text { Exceedance } \\
\text { Probability }\end{array}$ \\
\hline Baseflow & 0.45 & 15.75 & -- \\
$\mathbf{2}$ & 17.58 & 621 & $50 \%$ \\
$\mathbf{1 0}$ & 32.00 & 1130 & $10 \%$ \\
$\mathbf{1 0 0}$ & 51.82 & 1830 & $1 \%$ \\
\hline
\end{tabular}

\section{LWD Mobility}

\section{GIS Analysis}

Equation (3) is written as one expression with two equal signs. I separated equation (3) into two separate expressions, the first (4) which represents a wood buoyancy index and the second (5) which represents a drag force index:

$$
\begin{gathered}
Y_{R}^{B}=a_{R}{\frac{\rho_{w} d_{w}}{\rho_{\log } D_{\log }}}^{1+b_{R}} \\
Y_{R}=\frac{1}{1+C_{a} X_{R}}
\end{gathered}
$$


I created three separate models in ArcGIS v.10 using ArcGIS ModelBuilder (ESRI 2011) to represent the three expressions of equation (3); $X_{R}(2), Y_{R}^{B}(4)$, and $Y_{R}(5)$ (Appendix B). LWD mobility occurs when the value of $Y_{R}^{B}$ equals and exceeds the value of $Y_{R}$. When $Y_{r}$ is plotted against $X_{r}, Y_{R}=1$ when $X_{r}=0$, which is also the floatation threshold (Bocchiola et al, 2006a). When values of $Y_{R}^{B}>1$, drag $\left(Y_{R}\right)$ has little effect on LWD mobility and stability (Bocchiola et al., 2006a). Although not specifically addressed in the original published research, $\mathrm{Y}_{\mathrm{r}}$ can be negative under extreme conditions (e.g., near vertical bedslope), indicating that wood is mobilized by forces other than discharge (i.e., gravity). I converted negative $Y_{R}$ values to null values because they represented errors in the bathymetry interpolation. I compared the final $Y_{R}^{B}$ and $Y_{R}$ layers using the 'Greater Equal To' tool. The output from this tool is binary with '1' equal to mobility and '0' equal to stability. I converted stable areas to null values, and the final set of mobility pixels into polygon features necessary for the steps that account for LWD length in the spatial model results.

The resulting maps represent mobility based on LWD diameter without consideration of LWD length. For LWD mobilization to occur, this equation assumes that the full length of LWD is in contact with the channel bed and streamflow. I accounted for this in the GIS environment by assuming that a piece of LWD would only become mobile if a continuous block of mobility pixels with the same distance as LWD length was present within the study area. For example, a piece of LWD 1m long requires only one pixel to represent wood 
mobility. However, a piece of LWD 20m long requires a continuous sequence of 20 pixels to represent mobility.

I created a centerline for each initial mobility model using a predefined script (Dilts, 2011). The centerline was segmented into a series of small line lengths $(>1 \mathrm{~m})$. Flat-edge, un-dissolved buffers were created to represent the minimum, logarithmic midpoint (average), and maximum LWD lengths found in the study reach. I isolated the portions of the segmented buffer located completely within the initial mobility polygon. I exported these isolated segments of the buffer into a new feature class, and converted the polygon into a raster file, which represents a final mobility map that accounts for LWD diameter and length.

\section{LWD Mobility Probabilities}

I calculated the probability of each size class of wood moving during a flood event and the flood event occurring in any given year for the entire reach through the equation

$$
P(A \cap B)=P(A) \times P(B)
$$

Where $P(A)$ is equal to the proportion of wood mobility area to a specific flood area (2-year vs. 10-year vs. 100-year discharge), and $P(B)$ is equal to the probability of a given discharge occurring in any given year, the inverse of the 
flood return interval. The probability of a 2-year flood occurring in any given year is 0.5 , for a 10 -year flood is 0.1 , and for a 100 -year flood is 0.01 .

Equation (6) only holds true if the events are independent. If mobility occurred during multiple floods for a LWD size class, I calculated mobility probabilities by partitioning the flood and mobility areas by discharge event. I subtracted the flood and mobility areas of the 2-year flood from the 10-year flood, and subtracted the flood and mobility areas of the 10-year flood from the 100 year flood. 


\section{RESULTS}

\section{LWD Survey}

\section{LWD Size}

I measured a total 232 pieces of wood meeting the $>0.1 \mathrm{~m}$ diameter $/ 1.0 \mathrm{~m}$ length large woody debris classification criterion throughout the study reach. The maximum diameter measured was $1.7 \mathrm{~m}$ and the logarithmic midpoint diameter was $0.4 \mathrm{~m}$ (Figure 4.1). The maximum length measured was $47.2 \mathrm{~m}$ and the logarithmic midpoint length was $6.87 \mathrm{~m}$ (Figure 4.2). The majority of pieces are shorter than average bankfull channel width $(18.4 \mathrm{~m})$ when diameter and length of individual LWD pieces are plotted together (Figure 4.3).

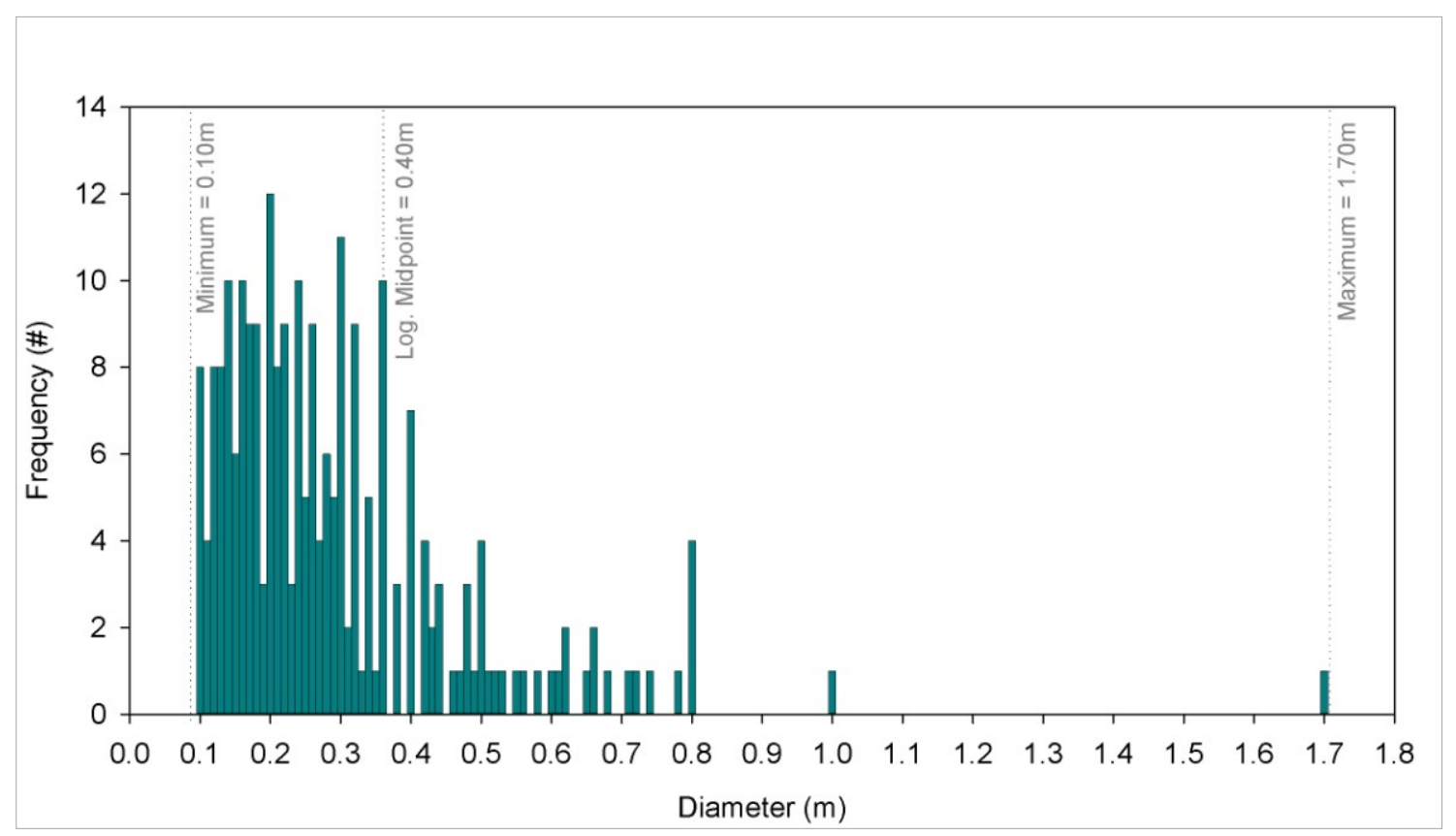

Figure 4.1: LWD diameter frequency distribution. Vertical dotted lines indicate the range of sizes used in the GIS model, i.e., $0.1 \mathrm{~m}, 0.4 \mathrm{~m}$, and $1.7 \mathrm{~m}$. 


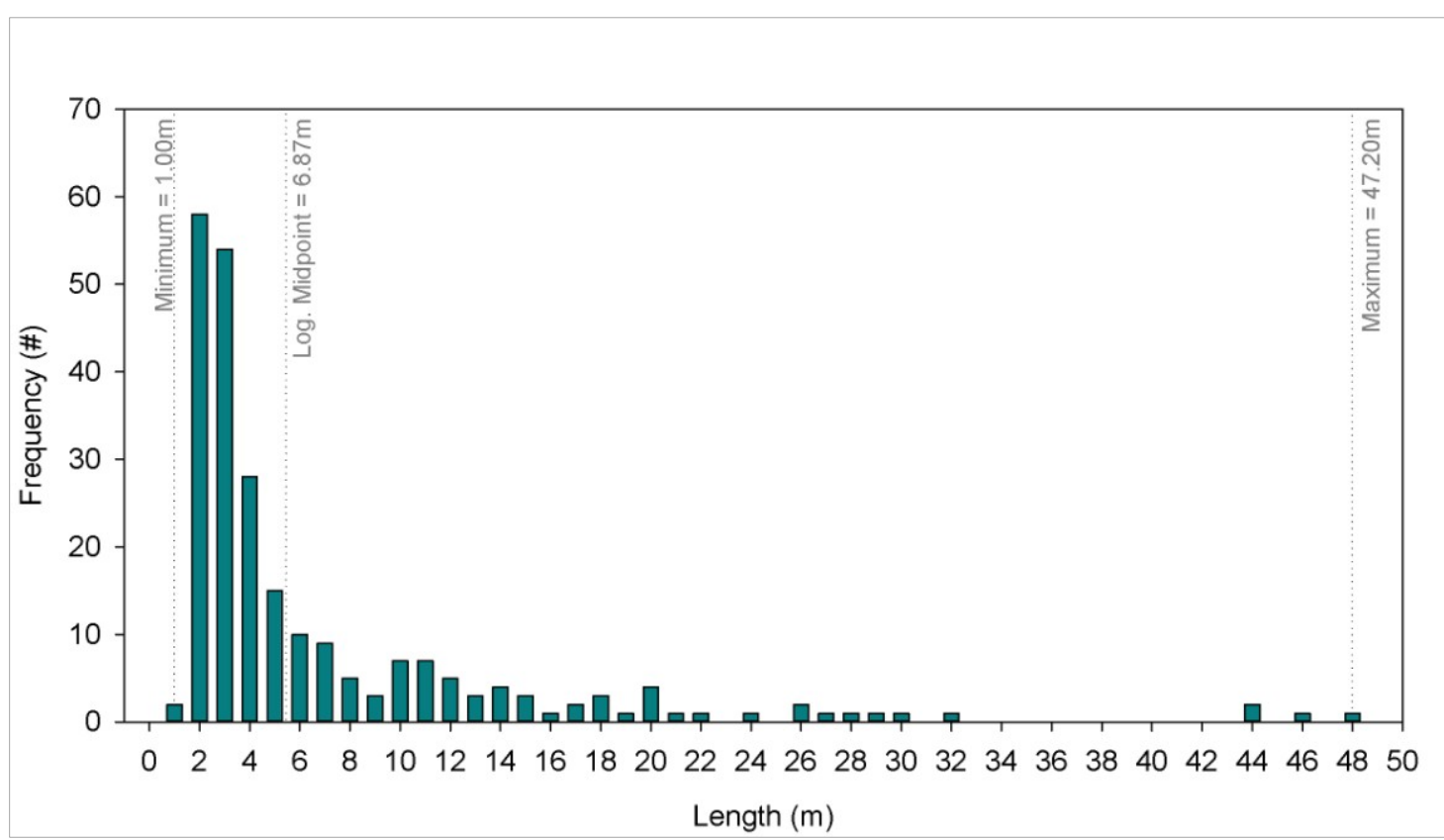

Figure 4.2: LWD length frequency distribution. Vertical dotted lines indicate the range of sizes used in the GIS model, i.e., $1.0 \mathrm{~m}, 6.87 \mathrm{~m}$, and $47.2 \mathrm{~m}$.

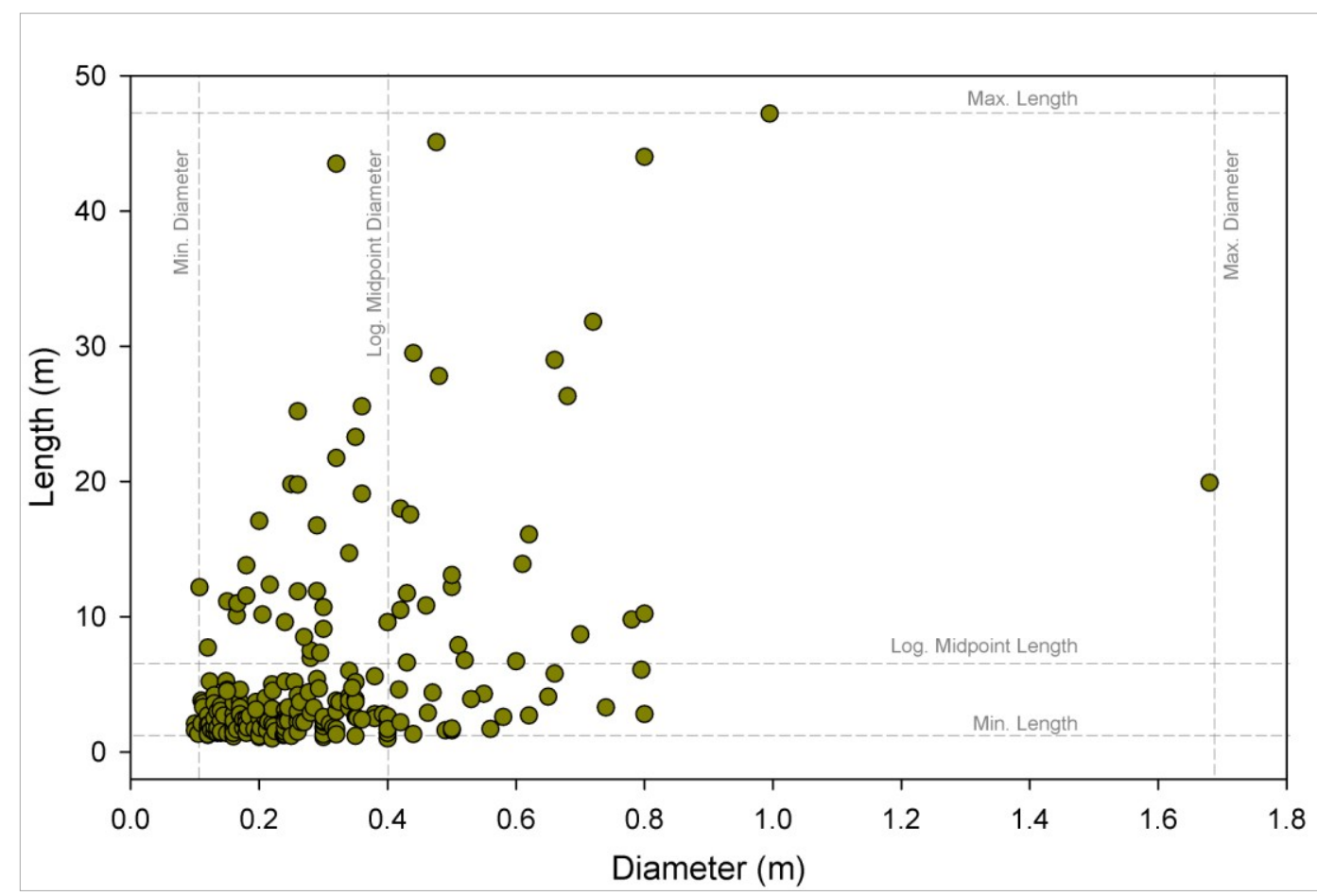

Figure 4.3: Scatterplot of LWD individual piece sizes in Cummins Creek, OR. 


\section{LWD Recruitment Process}

Fluvial redistribution accounted for 160 pieces (69\%) of the 232 LWD pieces surveyed. Bank erosion introduced 43 LWD pieces (19\%), while high winds introduced 29 LWD pieces (13\%) into the stream channel. Combined, stable LWD pieces, defined as pieces recruited by wind or bank erosion, account for 72 LWD pieces (31\%) in Cummins Creek (Figure 4.4). Mobile LWD has smaller mean diameters and lengths than stable LWD (Figure 4.5). Length comparisons of mobile and stable LWD revealed a similar difference. Wind $($ mean $=14.49 \mathrm{~m})$ and bank erosion $($ mean $=14.16 \mathrm{~m})$ have nearly the same LWD length compared to a mean length value of fluvially-redistributed wood $(3.04 \mathrm{~m})$.

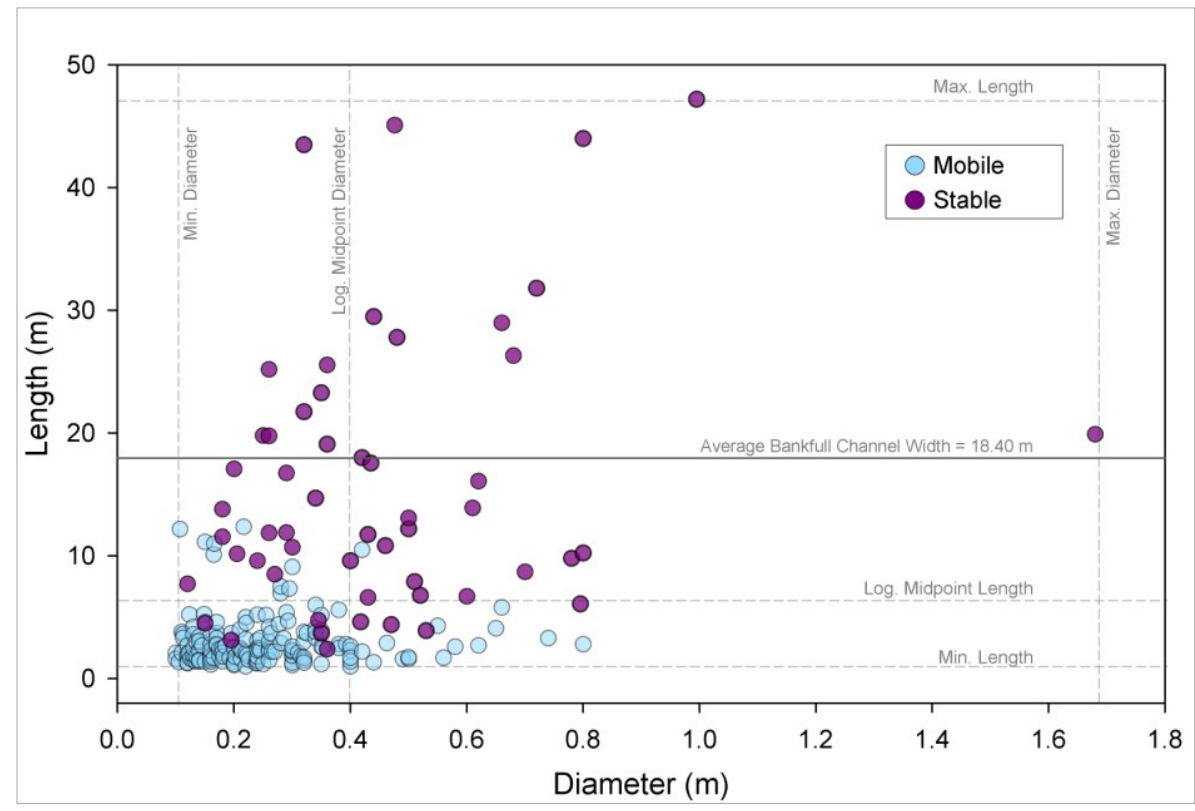

Figure 4.4: Scatterplot representing LWD diameter and length pairs when grouped by mobility status in Cummins Creek, OR. 


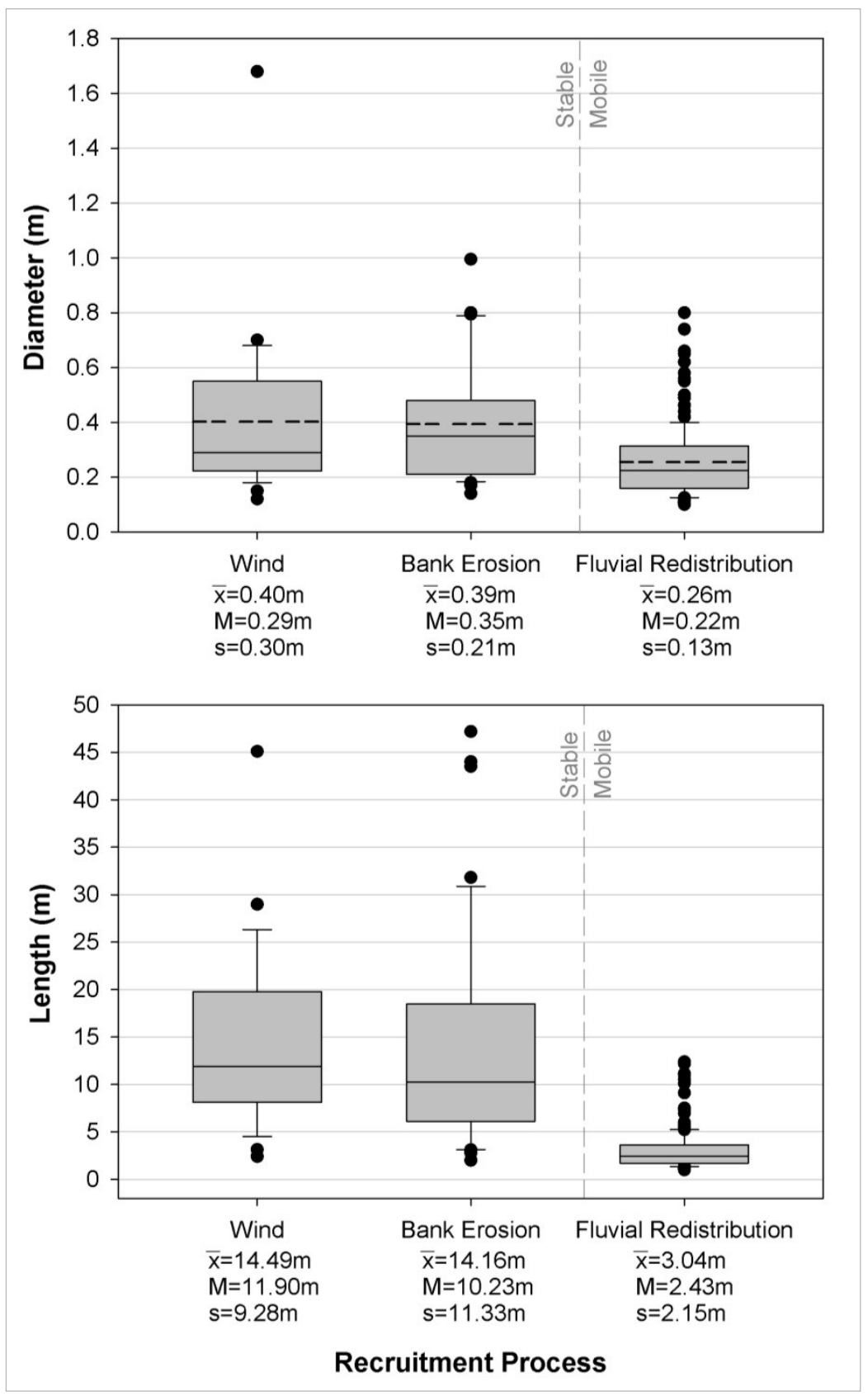

Figure 4.5: LWD diameter and length distributions grouped by recruitment process. The solid line represents the group median value, while the dashed line represents the mean value for a group. The mean $(x)$, median $(\mathrm{M})$, and standard deviation (s) diameter values are listed below each decay class group. The stable mobile line refers to the relative stability of each recruitment process; i.e., wood recruited by wind or bank erosion had not moved since the time of recruitment and were stable at the time of the wood survey. Fluvially-redistributed was mobile at some point before the wood survey. 


\section{Topographic Data}

Bathymetry data created during the DEM modification process was used to generate water depths in the flood analysis. A comparison of the pre- and post-modification LiDAR-DEM layers illustrate that the channel is more defined after incorporating field survey data information (Figure 2.3 vs. Figure 4.6). The slope layer created from the modified DEM demonstrates the study reach is adjacent to steep hillslopes. There are also portions of the stream bank that have steep slopes, indicative of incision into the floodplain (Figure 4.7).

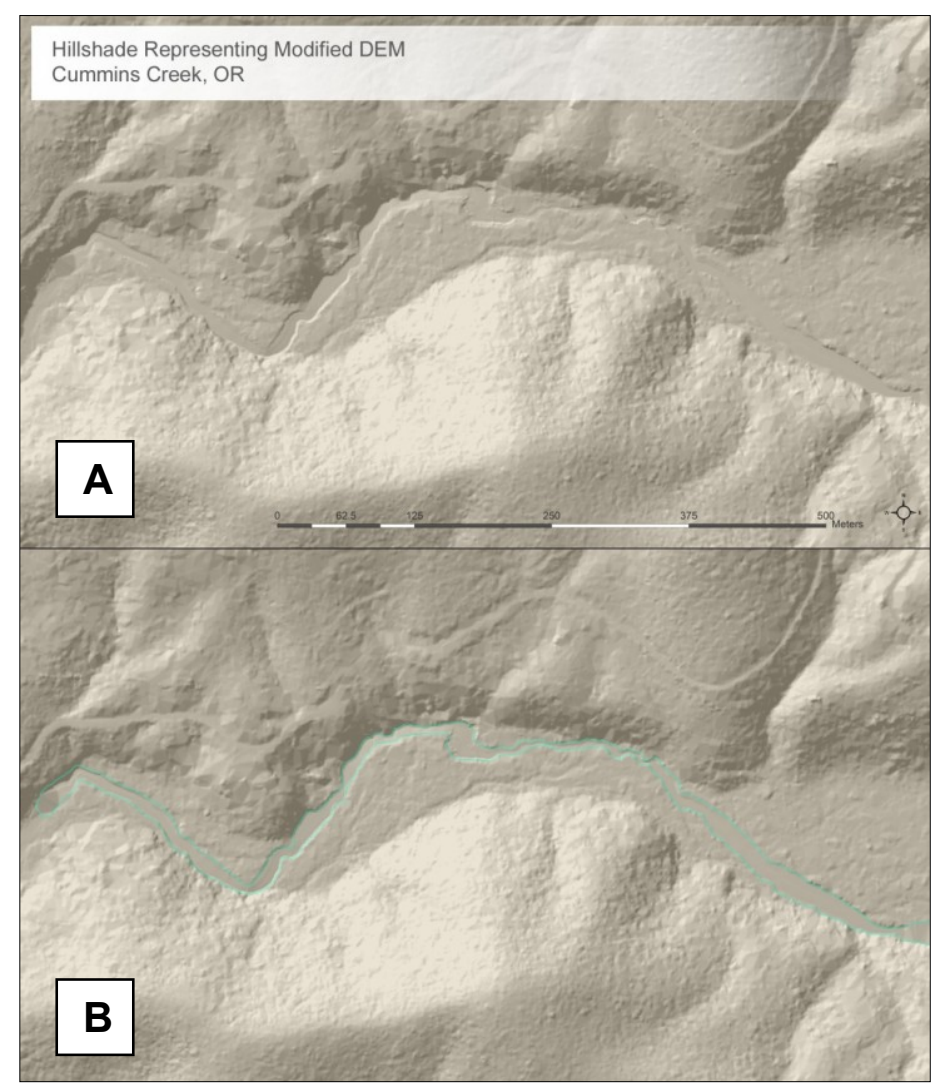

Figure 4.6: Image 'A' represents the modified hillshade map of Cummins Creek study reach illustrating local topographic relief. Note the defined channel banks compared to Figure 
4.2 , resulting from the DEM modification. Image $B$ defines the bankfull channel boundary of image " $A$ ' with the light blue line.

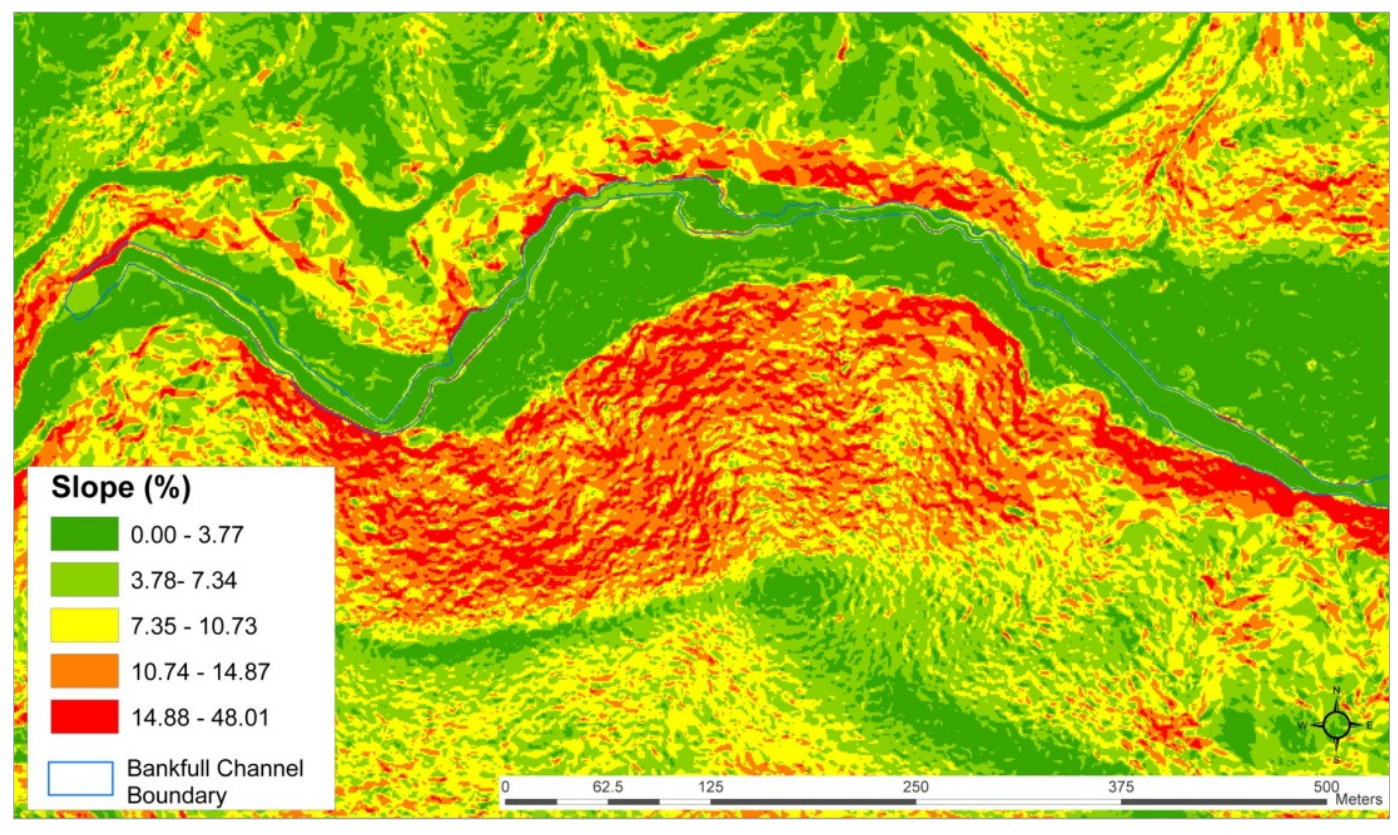

Figure 4.7: Slope map of Cummins Creek created from modified LiDAR-derived DEM.

\section{Water Depth and Velocity}

HEC-GeoRAS creates water surface elevation TIN layer based on the water surface elevations at each cross-section for the three modeled discharge values. I converted each TIN into a water surface DEM at the same resolution as the bathymetry DEM. The resulting water depth layers were derived by subtracting the bathymetry from the water surface elevation (Figures $4.8-4.10$ ). Velocity surfaces, an input layer in the GIS model, were also created during this process. Maximum velocity increased with each modeled discharge, from 2.54 
$\mathrm{m}^{2} / \mathrm{s}^{-1}$ during the 2-year event to $3.30 \mathrm{~m}^{2} / \mathrm{s}^{-1}$ during the 100 -year event (Figures

4.10-4.12).

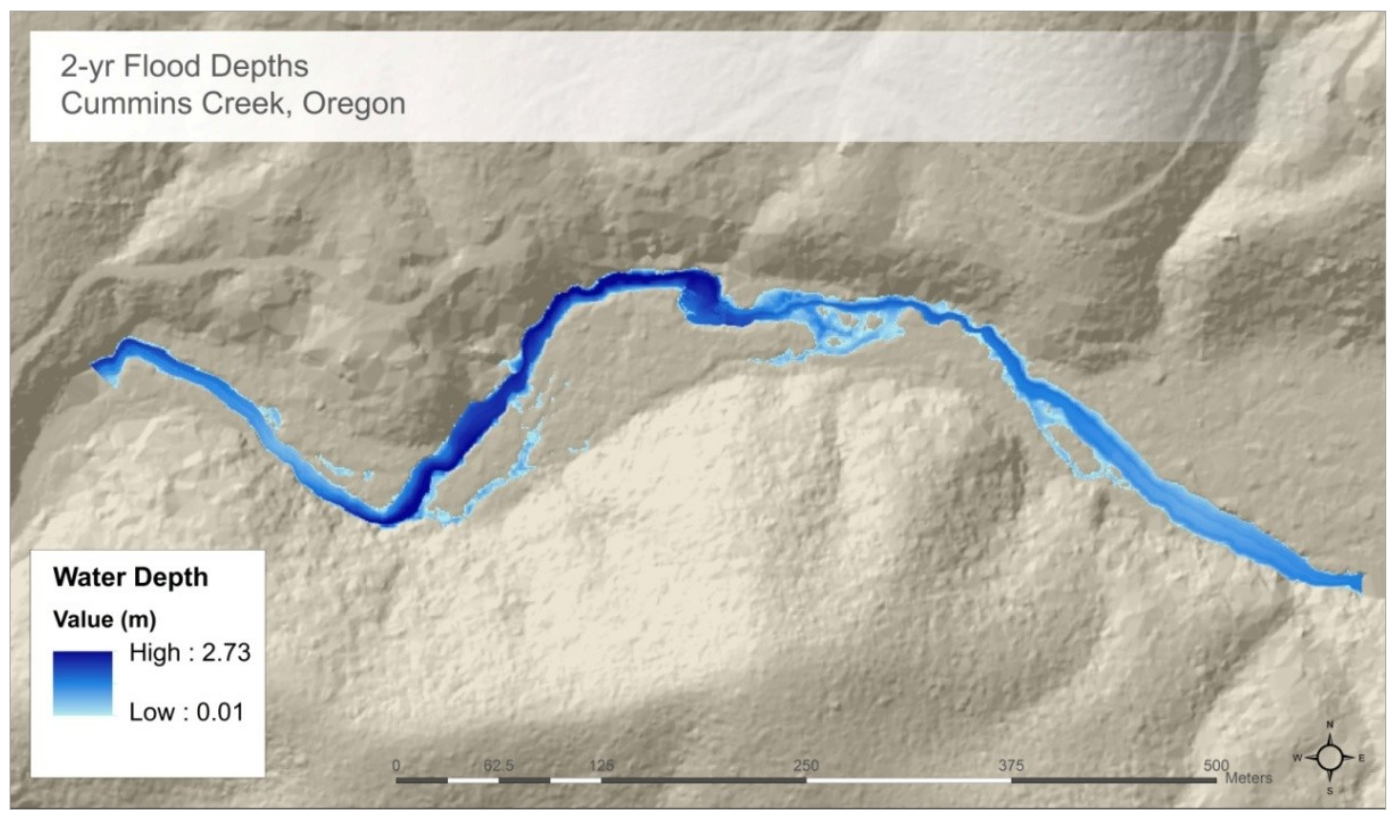

Figure 4.8: 2-year Water Depth Map at Cummins Creek, OR. Resulting values are rounded to the hundredth to set a minimum depth of $1 \mathrm{~mm}$. Values less than $1 \mathrm{~cm}$ were set as null values.

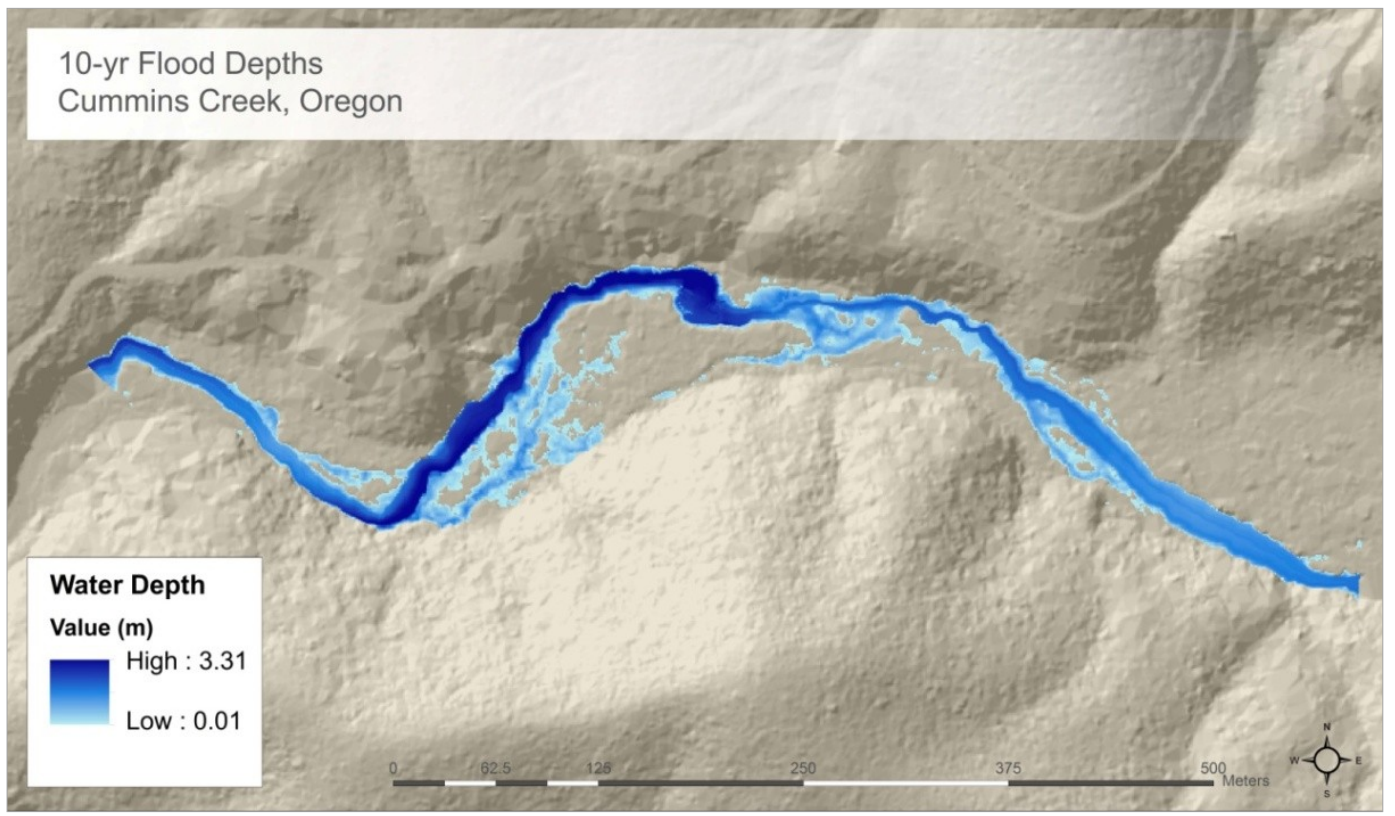


Figure 4.9: 10-year Water Depth Map at Cummins Creek, OR. Resulting values are rounded to the hundredth to set a minimum depth of $1 \mathrm{~mm}$. Values less than $1 \mathrm{~cm}$ were set as null values.

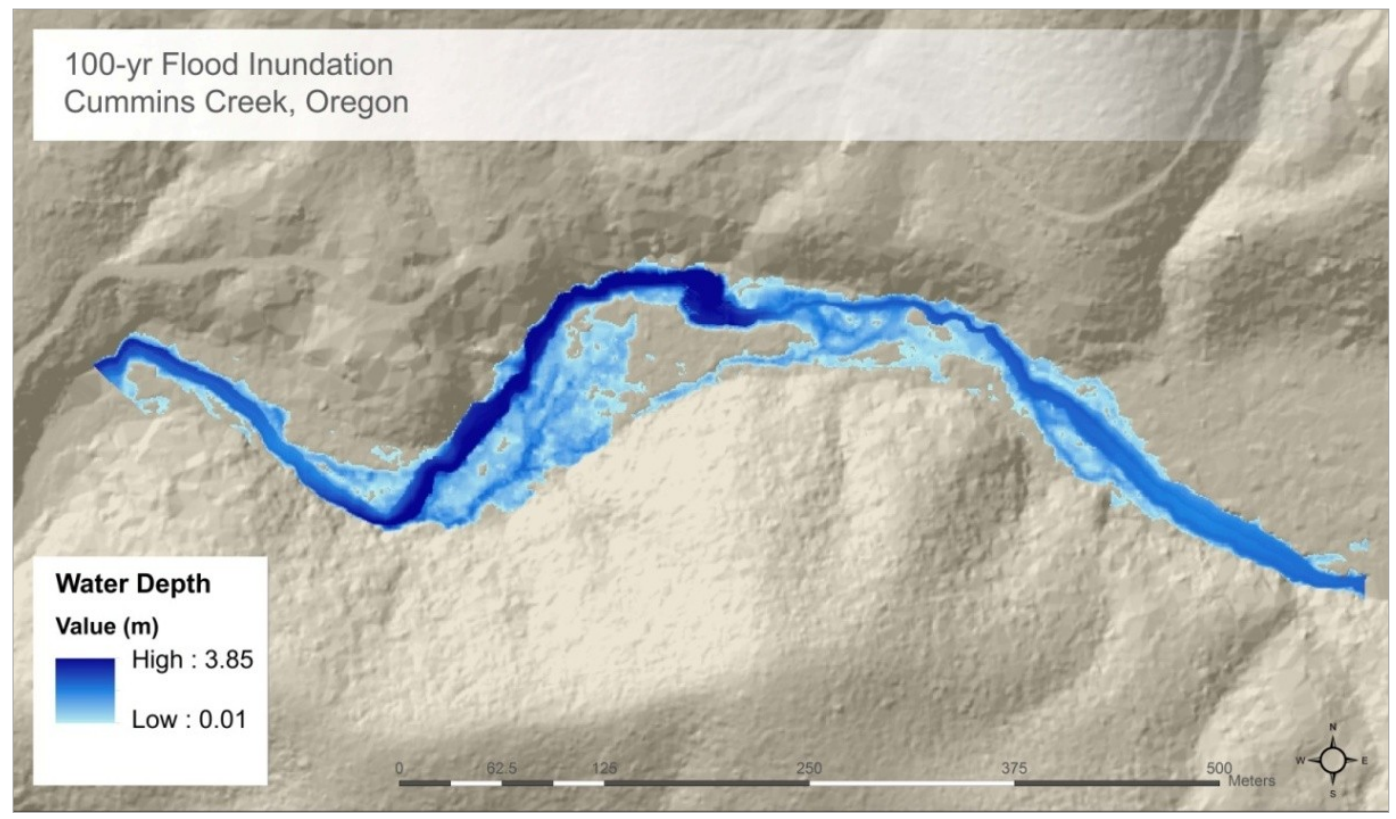

Figure 4.10: 100-year Water Depth Map at Cummins Creek, OR. Resulting values are rounded to the hundredth to set a minimum depth of $1 \mathrm{~mm}$. Values less than $1 \mathrm{~cm}$ were set as null values.

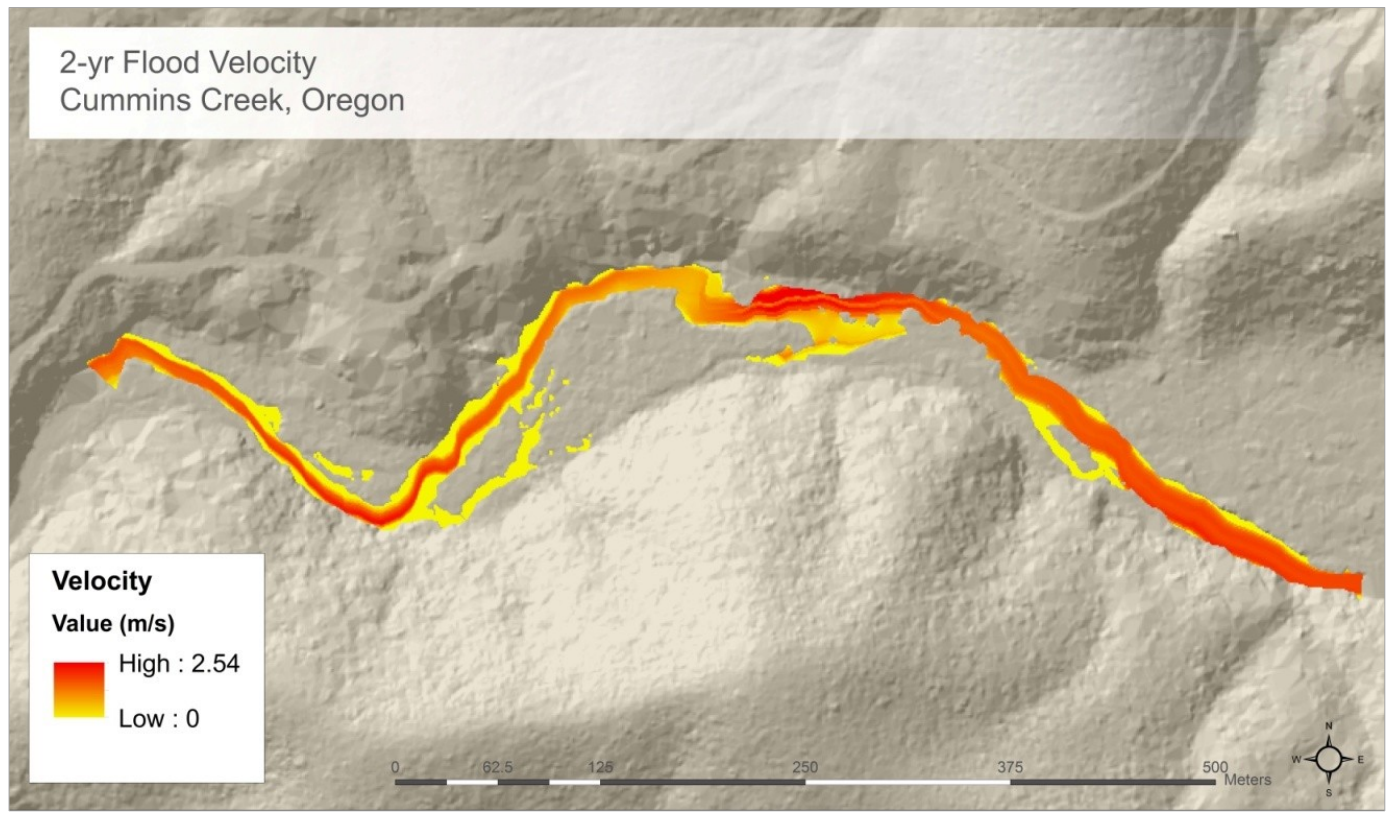

Figure 4.11: 2-year Water velocity map at Cummins Creek, OR. 


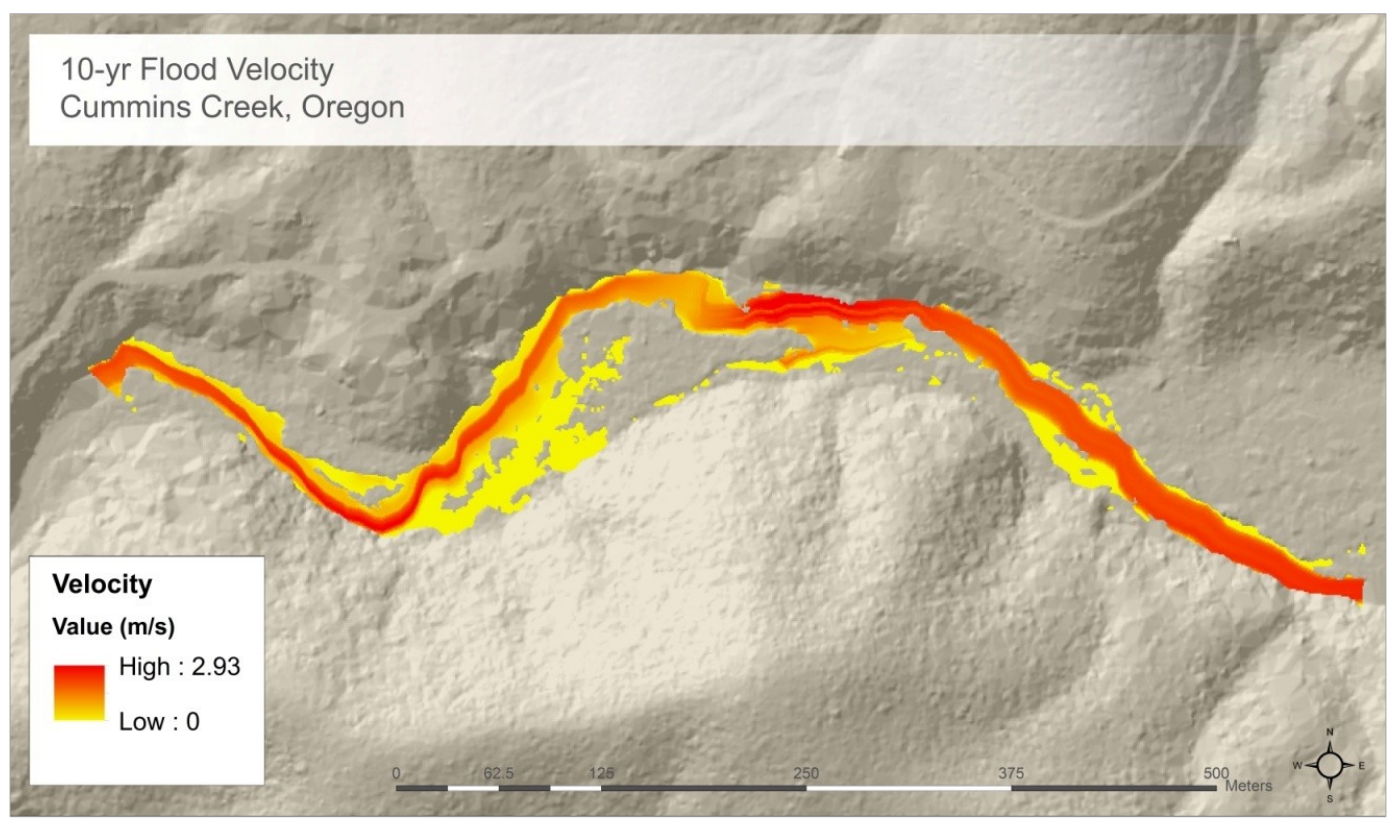

Figure 4.12: 10-year Water velocity map at Cummins Creek, OR.

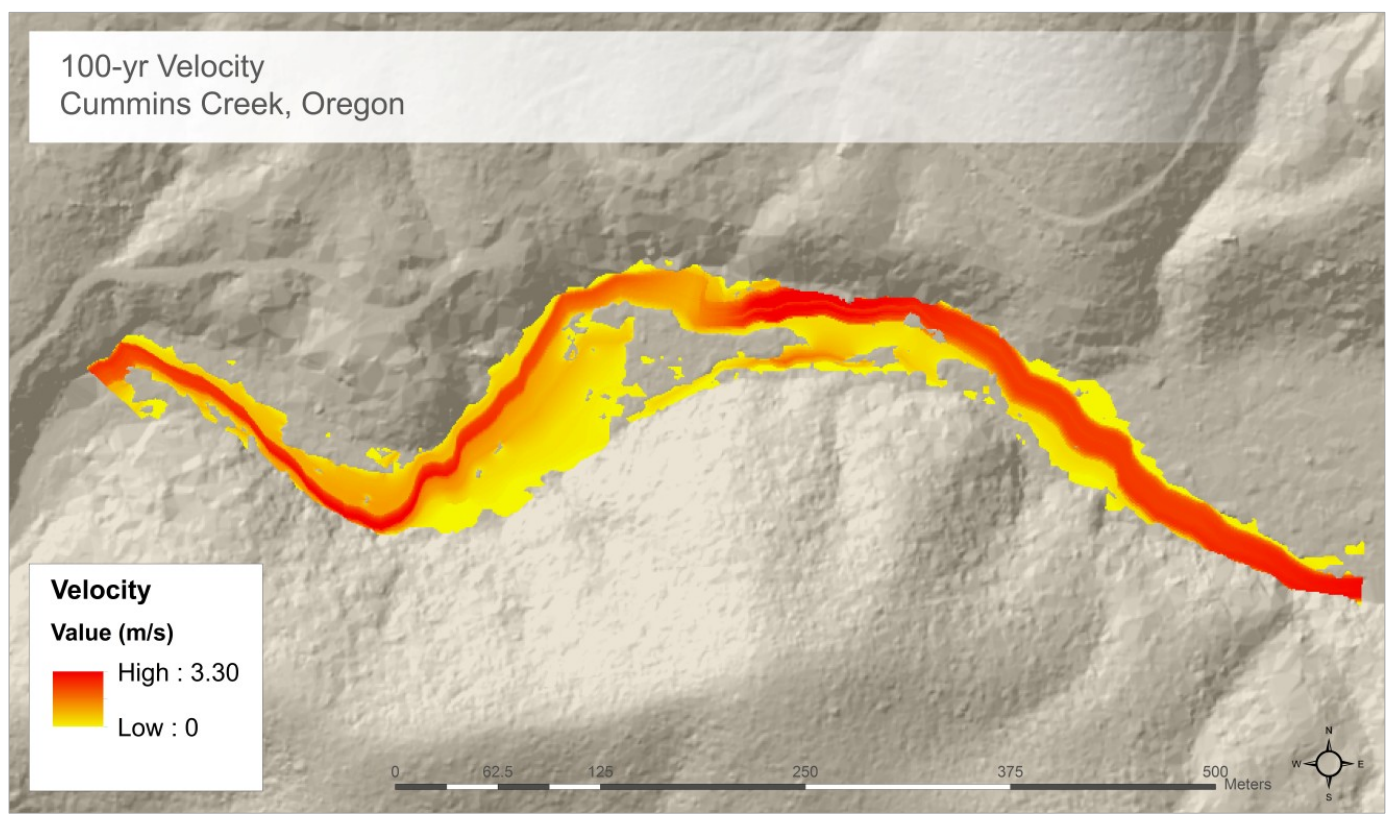

Figure 4.13: 100-year Water velocity map at Cummins Creek, OR 


\section{Modeling LWD Mobility Areas}

\section{Initial Mobility Scenarios}

Three maps (Figures $4.14-4.16$ ) are visualizations of initial LWD mobility areas when the only wood dimension considered is diameter. These maps represent the areas where wood buoyancy exceeds drag force $\left(Y_{R}^{B}>Y_{r}\right)$. I created one initial mobility map for each flood magnitude that visualizes mobility areas for all the modeled diameters. Total LWD mobility area increased with flood discharge magnitude for all modeled LWD diameters but the proportion of LWD mobility area to discharge area decreased with increasing diameter (Table

\section{1)}

Table 4.1: Initial mobility areas by discrete values and percentage of total flood inundation area by LWD diameter and discharge magnitude.

\begin{tabular}{|c|c|c|c|c|c|c|c|c|}
\hline \multirow[b]{3}{*}{$\begin{array}{l}\text { Flood } \\
\text { Event }\end{array}$} & \multirow{3}{*}{$\begin{array}{c}\text { Peak Flow } \\
\text { Discharge } \\
\left(\mathrm{m}^{2} \mathrm{~s}^{-1}\right)\end{array}$} & \multirow[b]{3}{*}{$\begin{array}{c}\text { Area } \\
\left(\mathrm{m}^{2}\right) \\
\end{array}$} & \multicolumn{6}{|c|}{ Initial Mobility Area $\left(\mathrm{m}^{2}\right)$} \\
\hline & & & \multicolumn{2}{|c|}{$0.1 \mathrm{~m}$ Diameter } & \multicolumn{2}{|c|}{$0.4 \mathrm{~m}$ Diameter } & \multicolumn{2}{|c|}{ 1.7m Diameter } \\
\hline & & & $\mathrm{m}^{2}$ & $\%$ & $\mathrm{~m}^{2}$ & $\%$ & $\mathrm{~m}^{2}$ & $\%$ \\
\hline $2-y r$ & 17.58 & 19102 & 15013 & 79 & 12750 & 67 & 8515 & 45 \\
\hline $10-y r$ & 32.00 & 26989 & 20517 & 76 & 16670 & 62 & 11469 & 42 \\
\hline $100-y r$ & 51.82 & 37052 & 29287 & 79 & 23963 & 65 & 14037 & 38 \\
\hline
\end{tabular}




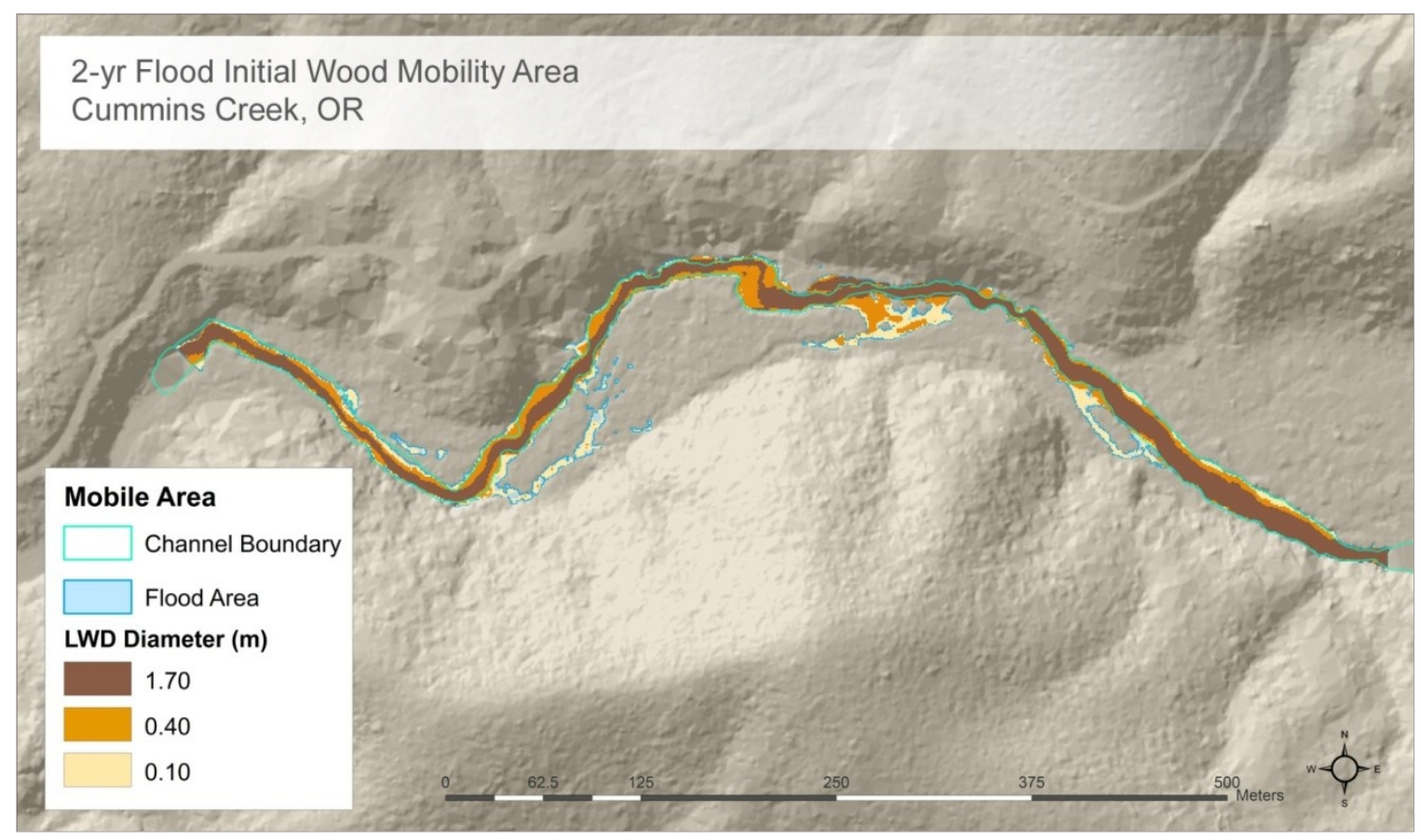

Figure 4.14: LWD mobility map representing a 2-yr flood when only considering diameter. Note that a lower size class is also mobile in the same areas where a larger size class is mobile, e.g., the $0.1 \mathrm{~m}$ class is mobile in the area where the .040 and 1.7 size pieces are mobile.

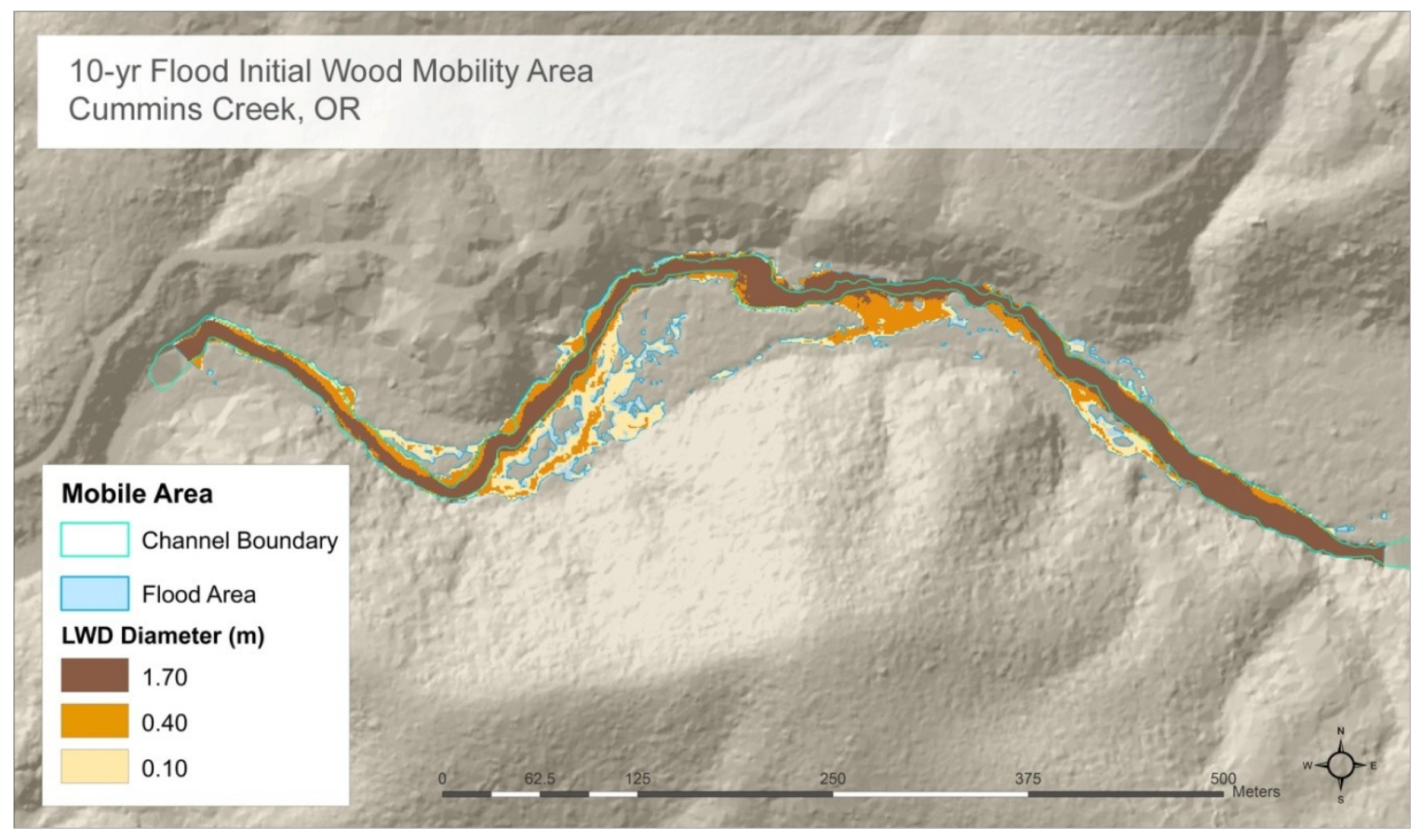

Figure 4.15: LWD mobility map representing a 10-yr flood when only considering diameter. 


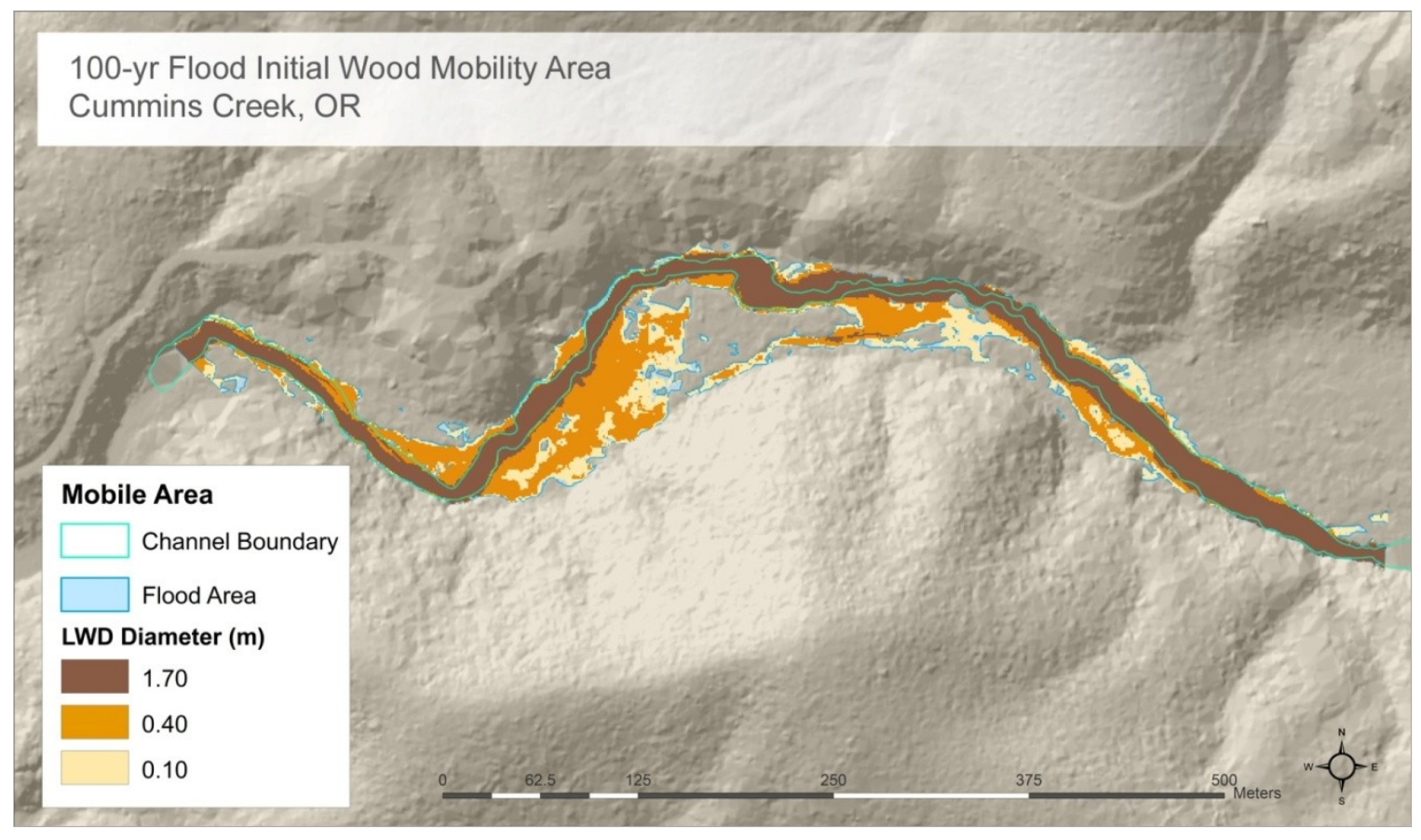

Figure 4.16: LWD mobility map representing an 100-yr flood when only considering diameter.

\section{Final LWD Mobility Scenarios}

The incipient motion areas in the initial maps become the base area for the final mobility maps based on diameter and length (Figures 4.17-4.24). I provide the final mobility area values in Table 4.2. Just as with the initial mobility areas, the total amount of LWD mobility area increases with increasing diameter, while the proportion of LWD mobility area to flood inundation area decreases with increasing diameter and length.

Incipient motion occurs during the 2-year, 10-year, and 100-year discharge events for the following LWD diameter and length size combinations: 
$0.1 \mathrm{~m} / 1.0 \mathrm{~m}$ (Figure 4.17 ), $0.1 \mathrm{~m} / 6.87 \mathrm{~m}$ (Figure 4.18 ), $0.4 \mathrm{~m} / 1.0 \mathrm{~m}$ (Figure 4.20 ), $0.4 \mathrm{~m} / 6.87 \mathrm{~m}$ (Figure 4.21), $1.7 \mathrm{~m} / 1.0 \mathrm{~m}$ (Figure 4.23 ), and $1.7 \mathrm{~m} / 6.87 \mathrm{~m}$ (Figure 4.24). Mobility probabilities within the entire study reach decreases between the 2-year, 10-year, and 100-year discharge events for each of these size combinations (Tables 4.3, 4.4, 4.6, 4.7, 4.9, 4.10). Incipient motion is limited to the 100-year discharge event for $0.1 \mathrm{~m} / 47.2 \mathrm{~m}$ (Figure 4.19 ) and $0.4 \mathrm{~m} / 47.2 \mathrm{~m}$ (Figure 4.23) diameter and length size combinations. The probability of mobility is $0 \%$ during the 2-year and 10-year discharge events for $0.1 \mathrm{~m} / 47.2 \mathrm{~m}$ and $0.4 \mathrm{~m} / 47.2 \mathrm{~m}$ size LWD, and increases marginally to $0.13 \%$ and $0.02 \%$ during the 100-year discharge (Tables 4.5 and 4.8) Mobility does not occur for $1.7 \mathrm{~m} / 47.2 \mathrm{~m}$ size wood during the 2-year, 10-year, or 100-year discharge events.

Table 4.2: Final mobility areas by discrete values and percentage of flood inundation area by LWD diameter and discharge magnitude, grouped by LWD length.

\begin{tabular}{|c|c|c|c|c|c|c|c|c|c|}
\hline & \multirow{3}{*}{$\begin{array}{l}\text { Flood } \\
\text { Return } \\
\text { Interval }\end{array}$} & \multirow[b]{3}{*}{$\begin{array}{c}\text { Peak Q } \\
\left(\mathrm{m}^{2} \mathrm{~s}^{-1}\right)\end{array}$} & \multirow{3}{*}{$\begin{array}{c}\text { Flood } \\
\text { Area } \\
\left(\mathrm{m}^{2}\right) \\
\end{array}$} & \multicolumn{6}{|c|}{ Final Mobility Area } \\
\hline & & & & \multicolumn{2}{|c|}{$\begin{array}{c}0.1 \mathrm{~m} \\
\text { Diameter }\end{array}$} & \multicolumn{2}{|c|}{$\begin{array}{c}0.4 \mathrm{~m} \\
\text { Diameter }\end{array}$} & \multicolumn{2}{|c|}{ 1.7m Diameter } \\
\hline & & & & $\mathrm{m}^{2}$ & $\%$ & $\mathrm{~m}^{2}$ & $\%$ & $\mathrm{~m}^{2}$ & $\%$ \\
\hline \multirow{3}{*}{$\stackrel{g}{g}$} & $2-y r$ & 17.58 & 19102 & 15013 & 79 & 12750 & 67 & 8515 & 45 \\
\hline & $10-y r$ & 32.00 & 26989 & 20517 & 76 & 16670 & 62 & 11469 & 42 \\
\hline & $100-y r$ & 51.82 & 37052 & 29287 & 79 & 23963 & 65 & 14037 & 38 \\
\hline \multirow{3}{*}{ 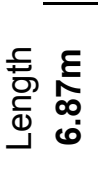 } & $2-y r$ & 17.58 & 19102 & 13330 & 70 & 11956 & 63 & 6162 & 39 \\
\hline & $10-y r$ & 32.00 & 26989 & 18113 & 67 & 15414 & 57 & 10758 & 48 \\
\hline & $100-y r$ & 51.82 & 37052 & 26850 & 72 & 21477 & 58 & 13593 & 34 \\
\hline \multirow{3}{*}{ શ̃ } & $2-y r$ & 17.58 & 19102 & 0 & 0 & 0 & 0 & 0 & 0 \\
\hline & $10-y r$ & 32.00 & 26989 & 0 & 0 & 0 & 0 & 0 & 0 \\
\hline & $100-y r$ & 51.82 & 37052 & 4647 & 15 & 918 & 3 & 0 & 0 \\
\hline
\end{tabular}


Table 4.3: Probability of mobility for $0.1 \mathrm{~m} / 1.0 \mathrm{~m}$ length wood during any given year within the entire study reach.

\begin{tabular}{cccc}
\hline & 2-year & 10-year & 100-year \\
\hline $\begin{array}{c}\text { Partitioned } \\
\text { Flood } \\
\text { Area }\end{array}$ & $19102 \mathrm{~m}^{2}$ & $7887 \mathrm{~m}^{2}$ & $10063 \mathrm{~m}^{2}$ \\
\hline $\begin{array}{c}\text { Mobility } \\
\text { Area }\end{array}$ & $14634 \mathrm{~m}^{2}$ & $5435 \mathrm{~m}^{2}$ & $8863 \mathrm{~m}^{2}$ \\
\hline $\begin{array}{c}\text { Percent } \\
\text { Mobility }\end{array}$ & $76.61 \%$ & $68.91 \%$ & $88.08 \%$ \\
\hline $\begin{array}{c}\text { Mobility } \\
\text { Probability }\end{array}$ & $38.30 \%$ & $6.89 \%$ & $0.88 \%$ \\
\hline
\end{tabular}

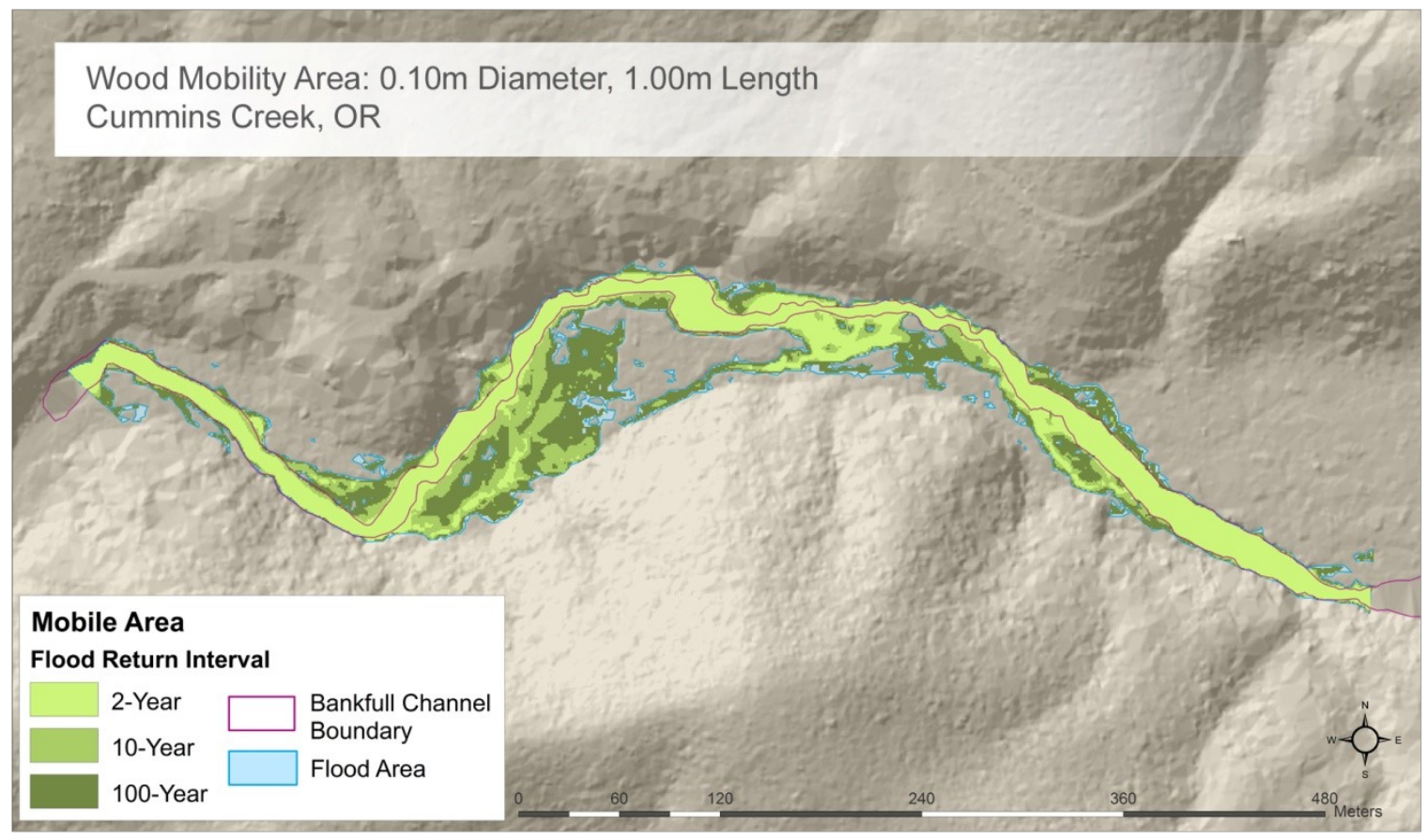

Figure 4.17: LWD mobility map for $0.1 \mathrm{~m}$ diameter/1.0m length wood during a 2-year, 10-year, and 100 -year flood. Figures 4.17-4.24 can be read as the 2-year discharge will mobilize wood in the light green areas, the 10-year discharge will mobilize additional wood found in the medium-green shaded areas, and the 100-year discharge will mobilize further additional wood found in the dark green shaded areas. 
Table 4.4: Probability of mobility for $0.1 \mathrm{~m} / 6.87 \mathrm{~m}$ length wood within the entire study reach.

\begin{tabular}{cccc}
\hline & 2-year & 10-year & 100-year \\
\hline $\begin{array}{c}\text { Partitioned } \\
\text { Flood } \\
\text { Area }\end{array}$ & $19102 \mathrm{~m}^{2}$ & $7887 \mathrm{~m}^{2}$ & $10063 \mathrm{~m}^{2}$ \\
\hline $\begin{array}{c}\text { Mobility } \\
\text { Area }\end{array}$ & $13330 \mathrm{~m}^{2}$ & $4783 \mathrm{~m}^{2}$ & $8737 \mathrm{~m}^{2}$ \\
\hline $\begin{array}{c}\text { Percent } \\
\text { Mobility }\end{array}$ & $69.78 \%$ & $60.64 \%$ & $86.82 \%$ \\
\hline $\begin{array}{c}\text { Mobility } \\
\text { Probability }\end{array}$ & $34.89 \%$ & $6.06 \%$ & $0.87 \%$ \\
\hline
\end{tabular}

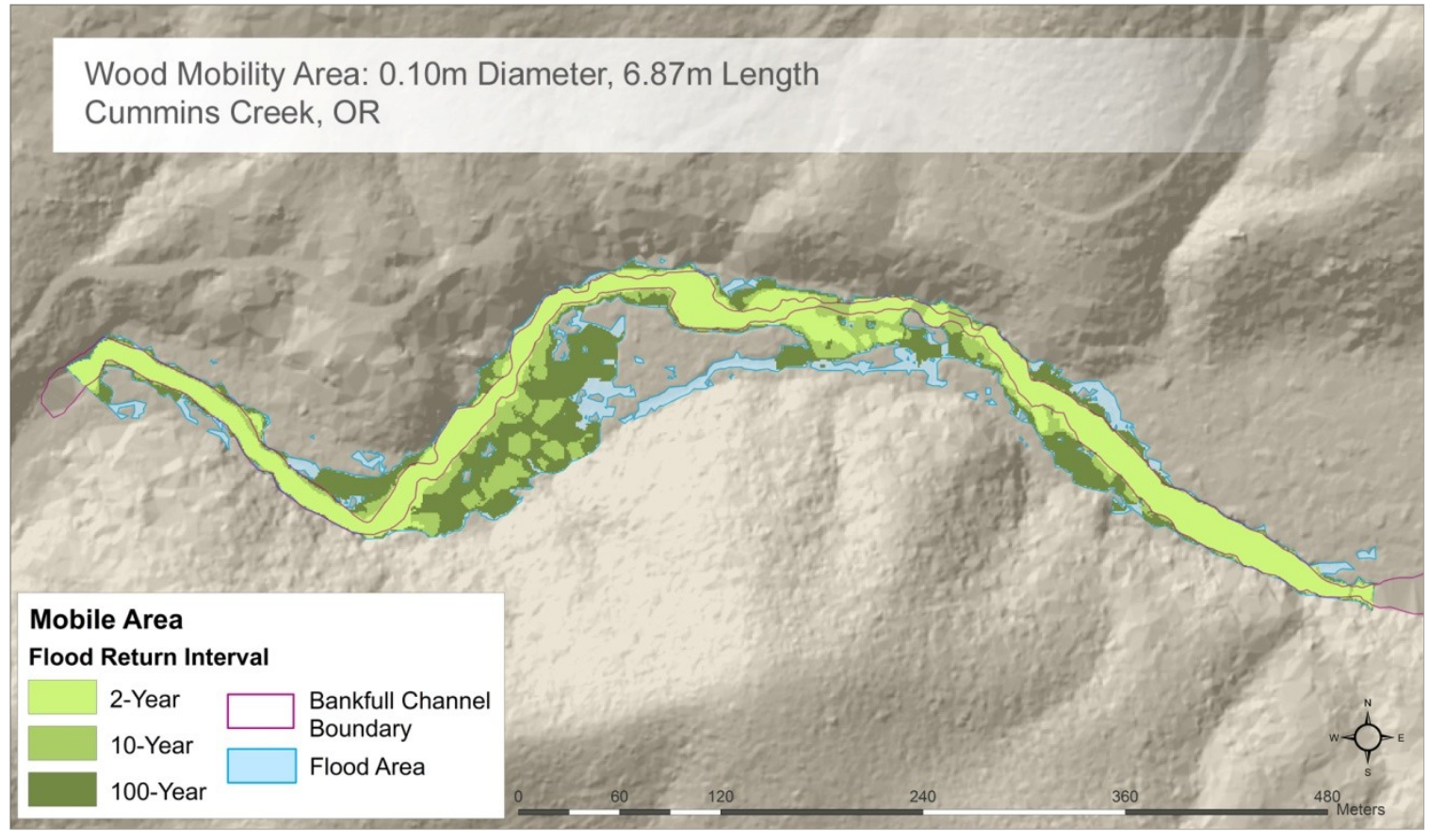

Figure 4.18: LWD mobility map for $0.1 \mathrm{~m}$ diameter $/ 6.87 \mathrm{~m}$ length wood during a 2-year, 10 -year, and 100-year flood. 
Table 4.5: Probability of mobility for $0.1 \mathrm{~m} / 47.2 \mathrm{~m}$ length wood within the entire study reach.

\begin{tabular}{cccc}
\hline & 2-year & 10-year & 100-year \\
\hline $\begin{array}{c}\text { Partitioned } \\
\text { Flood } \\
\text { Area }\end{array}$ & $19102 \mathrm{~m}^{2}$ & $7887 \mathrm{~m}^{2}$ & $37052 \mathrm{~m}^{2}$ \\
\hline $\begin{array}{c}\text { Mobility } \\
\text { Area }\end{array}$ & $0 \mathrm{~m}^{2}$ & $0 \mathrm{~m}^{2}$ & $4647 \mathrm{~m}^{2}$ \\
\hline $\begin{array}{c}\text { Percent } \\
\text { Mobility }\end{array}$ & $0 \%$ & $0 \%$ & $12.54 \%$ \\
\hline $\begin{array}{c}\text { Mobility } \\
\text { Probability }\end{array}$ & $0 \%$ & $0 \%$ & $0.13 \%$ \\
\hline
\end{tabular}

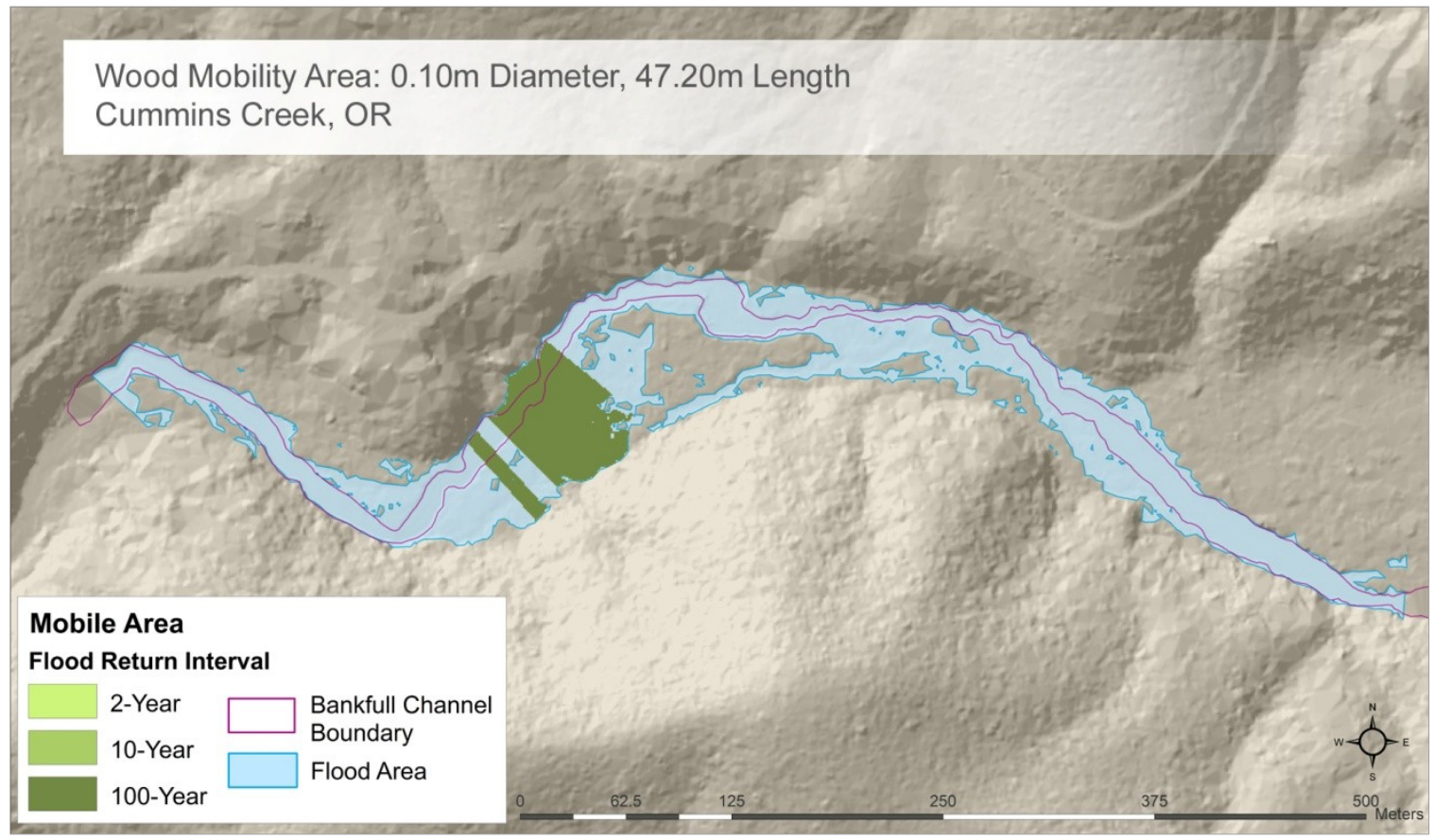

Figure 4.19: LWD mobility map for $0.1 \mathrm{~m}$ diameter/47.2m length wood during a 2-year, 10 -year, and 100-year flood. 
Table 4.6: Probability of mobility for $0.4 \mathrm{~m} / 1.0 \mathrm{~m}$ length wood within the entire study reach.

\begin{tabular}{cccc}
\hline & 2-year & 10-year & 100-year \\
\hline $\begin{array}{c}\text { Partitioned } \\
\text { Flood } \\
\text { Area }\end{array}$ & $19102 \mathrm{~m}^{2}$ & $7887 \mathrm{~m}^{2}$ & $10063 \mathrm{~m}^{2}$ \\
\hline $\begin{array}{c}\text { Mobility } \\
\text { Area }\end{array}$ & $12628 \mathrm{~m}^{2}$ & $3800 \mathrm{~m}^{2}$ & $7347 \mathrm{~m}^{2}$ \\
\hline $\begin{array}{c}\text { Percent } \\
\text { Mobility }\end{array}$ & $66.11 \%$ & $48.18 \%$ & $73.01 \%$ \\
\hline $\begin{array}{c}\text { Mobility } \\
\text { Probability }\end{array}$ & $33.05 \%$ & $4.82 \%$ & $0.73 \%$ \\
\hline
\end{tabular}

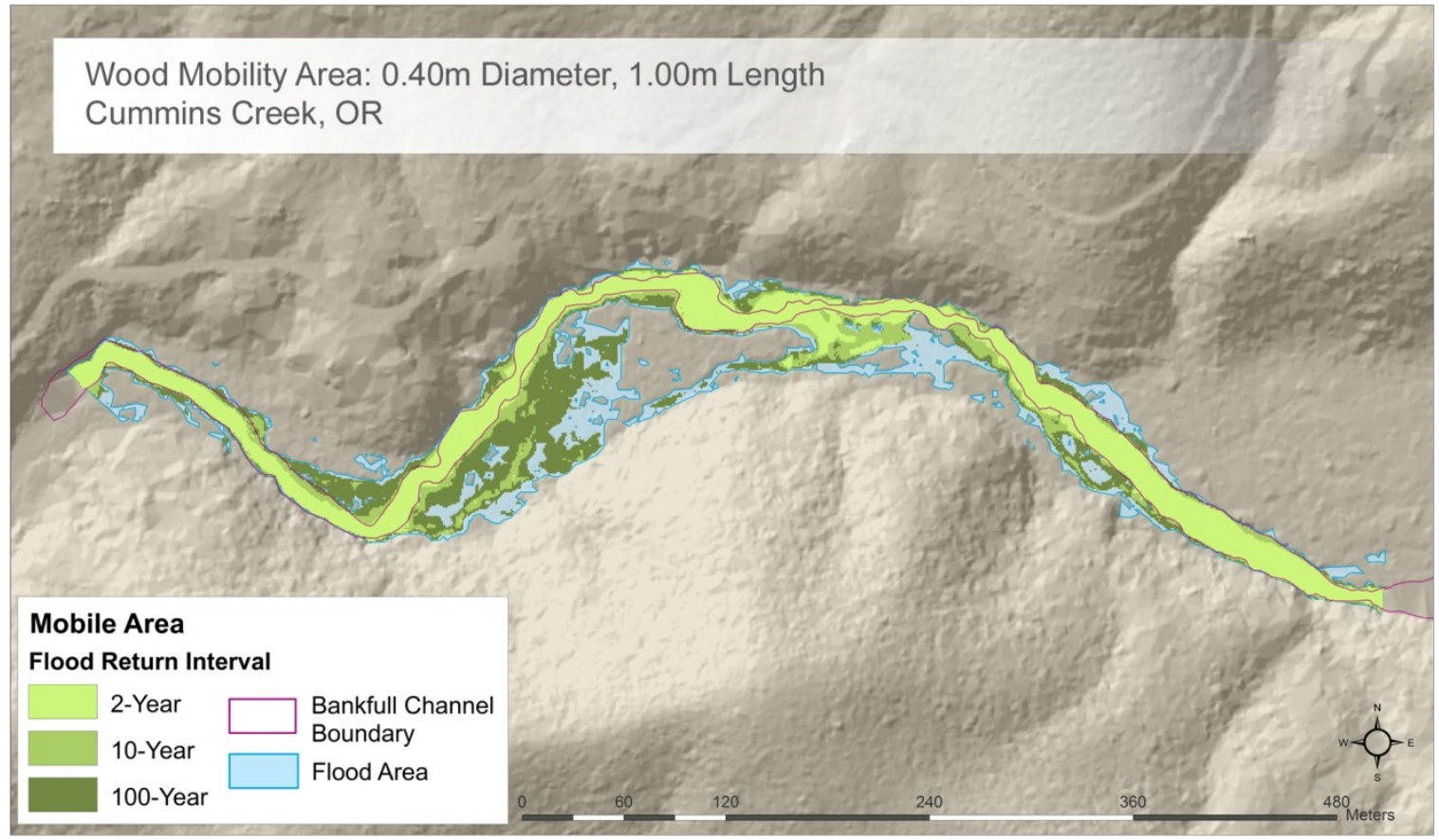

Figure 4.20: LWD mobility map for $0.4 \mathrm{~m}$ diameter/1.0m length wood during a 2-year, 10-year, and 100-year flood. 
Table 4.7: Probability of mobility for $0.4 \mathrm{~m} / 6.87 \mathrm{~m}$ length wood within the entire study reach.

\begin{tabular}{cccc}
\hline & 2-year & 10-year & 100-year \\
\hline $\begin{array}{c}\text { Partitioned } \\
\text { Flood } \\
\text { Area }\end{array}$ & $19102 \mathrm{~m}^{2}$ & $7887 \mathrm{~m}^{2}$ & $10063 \mathrm{~m}^{2}$ \\
\hline $\begin{array}{c}\text { Mobility } \\
\text { Area }\end{array}$ & $11956 \mathrm{~m}^{2}$ & $3458 \mathrm{~m}^{2}$ & $6063 \mathrm{~m}^{2}$ \\
\hline $\begin{array}{c}\text { Percent } \\
\text { Mobility }\end{array}$ & $62.59 \%$ & $43.84 \%$ & $60.25 \%$ \\
\hline $\begin{array}{c}\text { Mobility } \\
\text { Probability }\end{array}$ & $31.30 \%$ & $4.38 \%$ & $0.60 \%$ \\
\hline
\end{tabular}

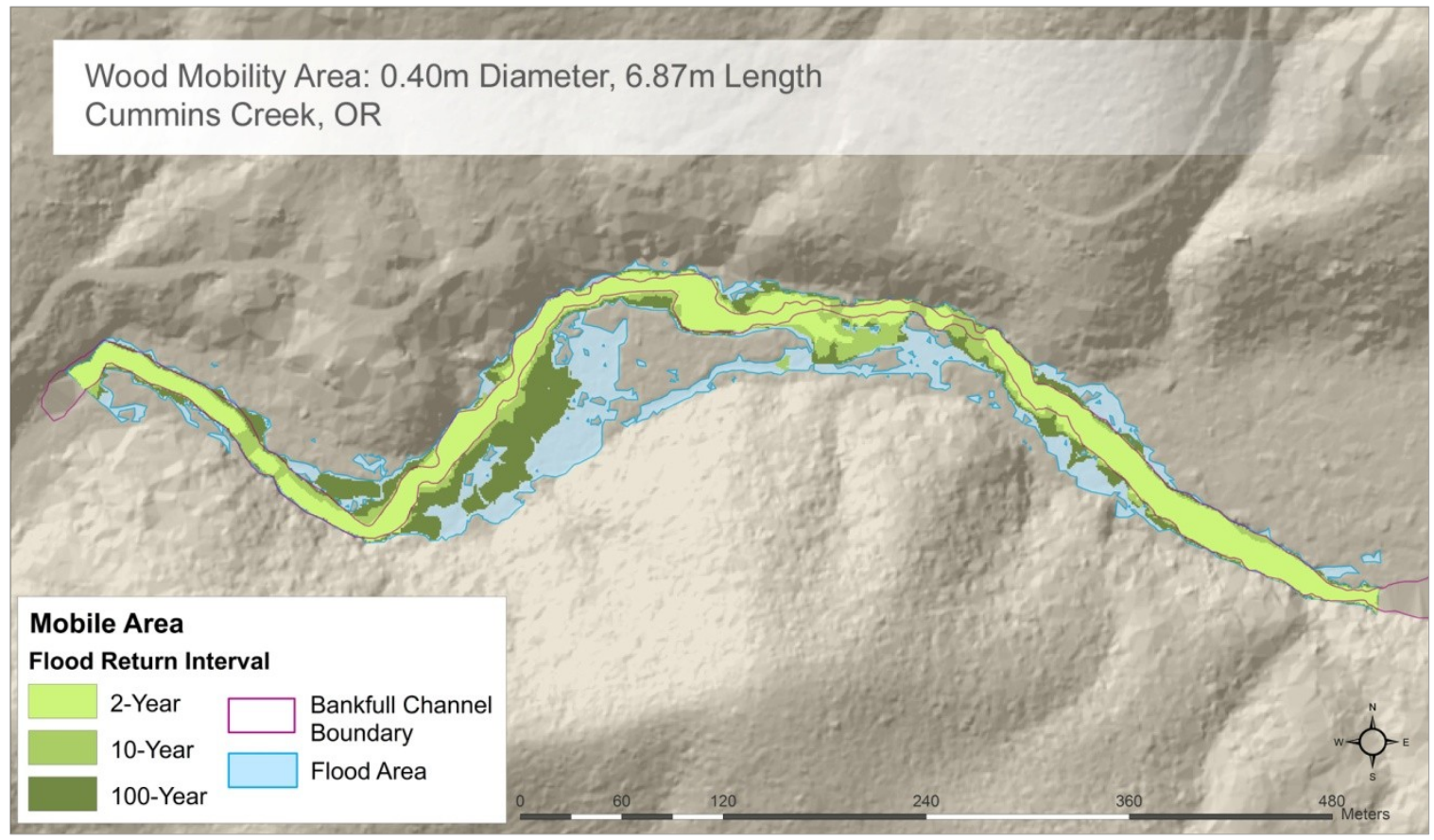

Figure 4.21: LWD mobility map for $0.4 \mathrm{~m}$ diameter $/ 6.87 \mathrm{~m}$ length wood during a 2-year, 10 -year, and 100-year flood. 
Table 4.8: Probability of mobility for $0.4 \mathrm{~m} / 47.2 \mathrm{~m}$ length wood within the entire study reach.

\begin{tabular}{cccc}
\hline & 2-year & 10-year & 100-year \\
\hline $\begin{array}{c}\text { Partitioned } \\
\text { Flood } \\
\text { Area }\end{array}$ & $19102 \mathrm{~m}^{2}$ & $7887 \mathrm{~m}^{2}$ & $37052 \mathrm{~m}^{2}$ \\
\hline $\begin{array}{c}\text { Mobility } \\
\text { Area }\end{array}$ & $0 \mathrm{~m}^{2}$ & $0 \mathrm{~m}^{2}$ & $918 \mathrm{~m}^{2}$ \\
\hline $\begin{array}{c}\text { Percent } \\
\text { Mobility }\end{array}$ & $0 \%$ & $0 \%$ & $2.48 \%$ \\
\hline $\begin{array}{c}\text { Mobility } \\
\text { Probability }\end{array}$ & $0 \%$ & $0 \%$ & $0.02 \%$ \\
\hline
\end{tabular}

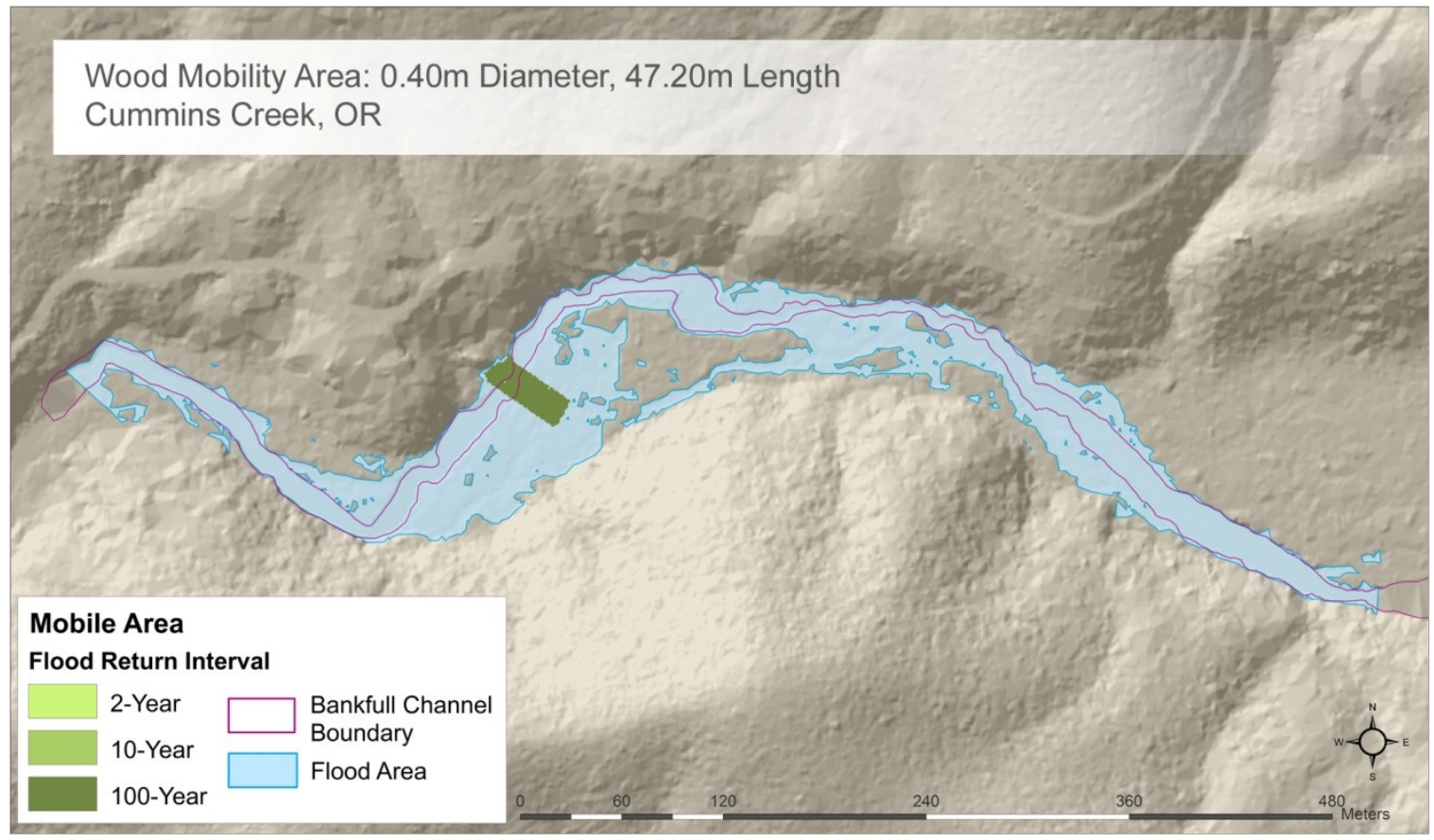

Figure 4.22: LWD mobility map for $0.4 \mathrm{~m}$ diameter/47.2m length wood during a 2-year, 10-year, and 100-year flood. 
Table 4.9: Probability of mobility for $1.7 \mathrm{~m} / 1.0 \mathrm{~m}$ length wood within the entire study reach.

\begin{tabular}{cccc}
\hline & 2-year & 10-year & 100-year \\
\hline $\begin{array}{c}\text { Partitioned } \\
\text { Flood } \\
\text { Area }\end{array}$ & $19102 \mathrm{~m}^{2}$ & $7887 \mathrm{~m}^{2}$ & $10063 \mathrm{~m}^{2}$ \\
\hline $\begin{array}{c}\text { Mobility } \\
\text { Area }\end{array}$ & $8423 \mathrm{~m}^{2}$ & $2957 \mathrm{~m}^{2}$ & $2587 \mathrm{~m}^{2}$ \\
\hline $\begin{array}{c}\text { Percent } \\
\text { Mobility }\end{array}$ & $44.09 \%$ & $37.49 \%$ & $25.71 \%$ \\
\hline $\begin{array}{c}\text { Mobility } \\
\text { Probability }\end{array}$ & $22.05 \%$ & $3.75 \%$ & $0.26 \%$ \\
\hline
\end{tabular}

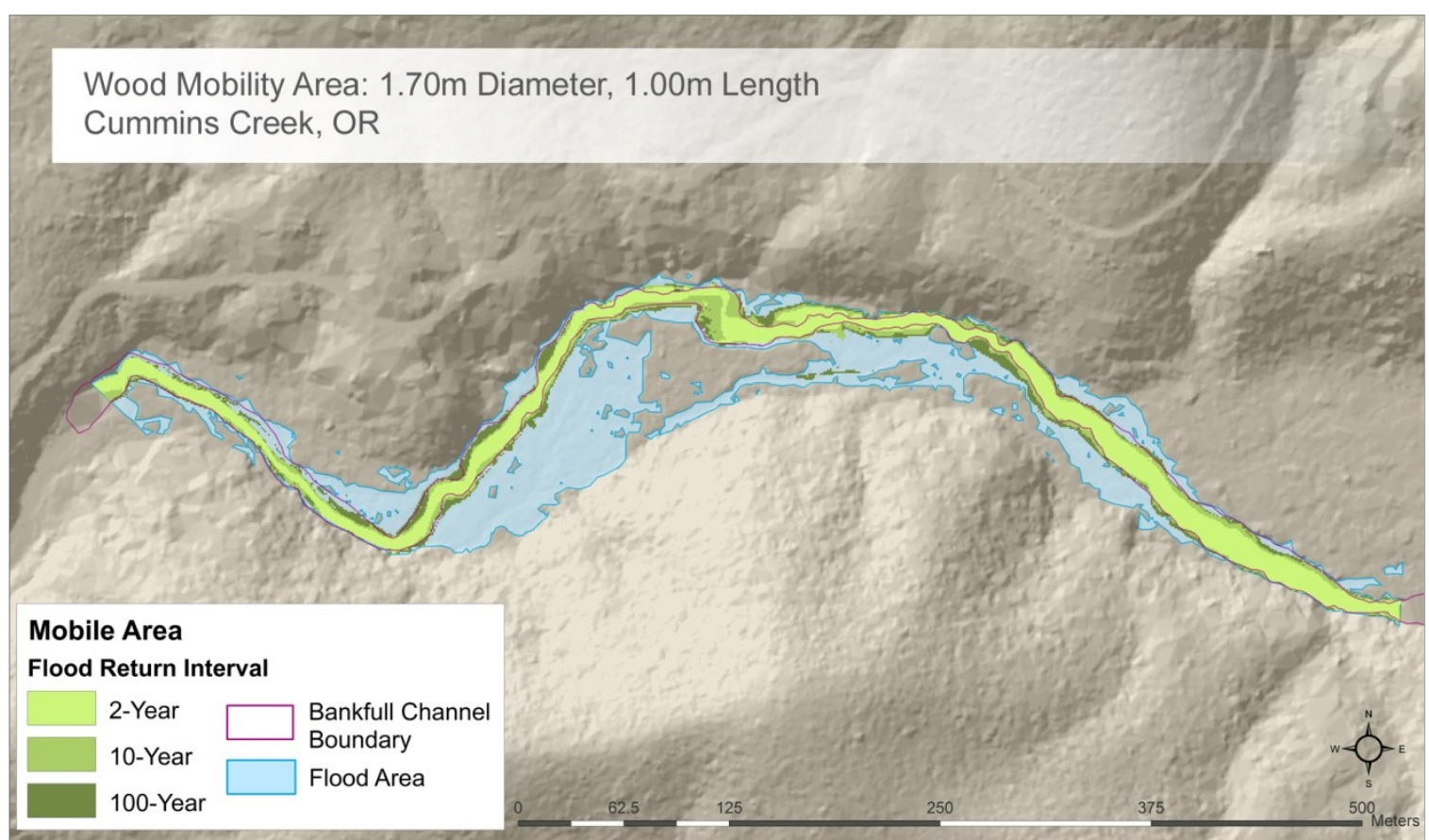

Figure 4.23: LWD mobility map for $1.7 \mathrm{~m}$ diameter/1.0m length wood during a 2-year, 10-year, and 100 -year flood. 
Table 4.10: Probability of mobility for $1.7 \mathrm{~m} / 6.87 \mathrm{~m}$ length wood within the entire study reach.

\begin{tabular}{cccc}
\hline & 2-year & 10-year & 100-year \\
\hline $\begin{array}{c}\text { Partitioned } \\
\text { Flood } \\
\text { Area }\end{array}$ & $19102 \mathrm{~m}^{2}$ & $7887 \mathrm{~m}^{2}$ & $10063 \mathrm{~m}^{2}$ \\
\hline $\begin{array}{c}\text { Mobility } \\
\text { Area }\end{array}$ & $6162 \mathrm{~m}^{2}$ & $4596 \mathrm{~m}^{2}$ & $2835 \mathrm{~m}^{2}$ \\
\hline $\begin{array}{c}\text { Percent } \\
\text { Mobility }\end{array}$ & $32.26 \%$ & $58.27 \%$ & $28.17 \%$ \\
\hline $\begin{array}{c}\text { Mobility } \\
\text { Probability }\end{array}$ & $16.13 \%$ & $5.83 \%$ & $0.28 \%$ \\
\hline
\end{tabular}

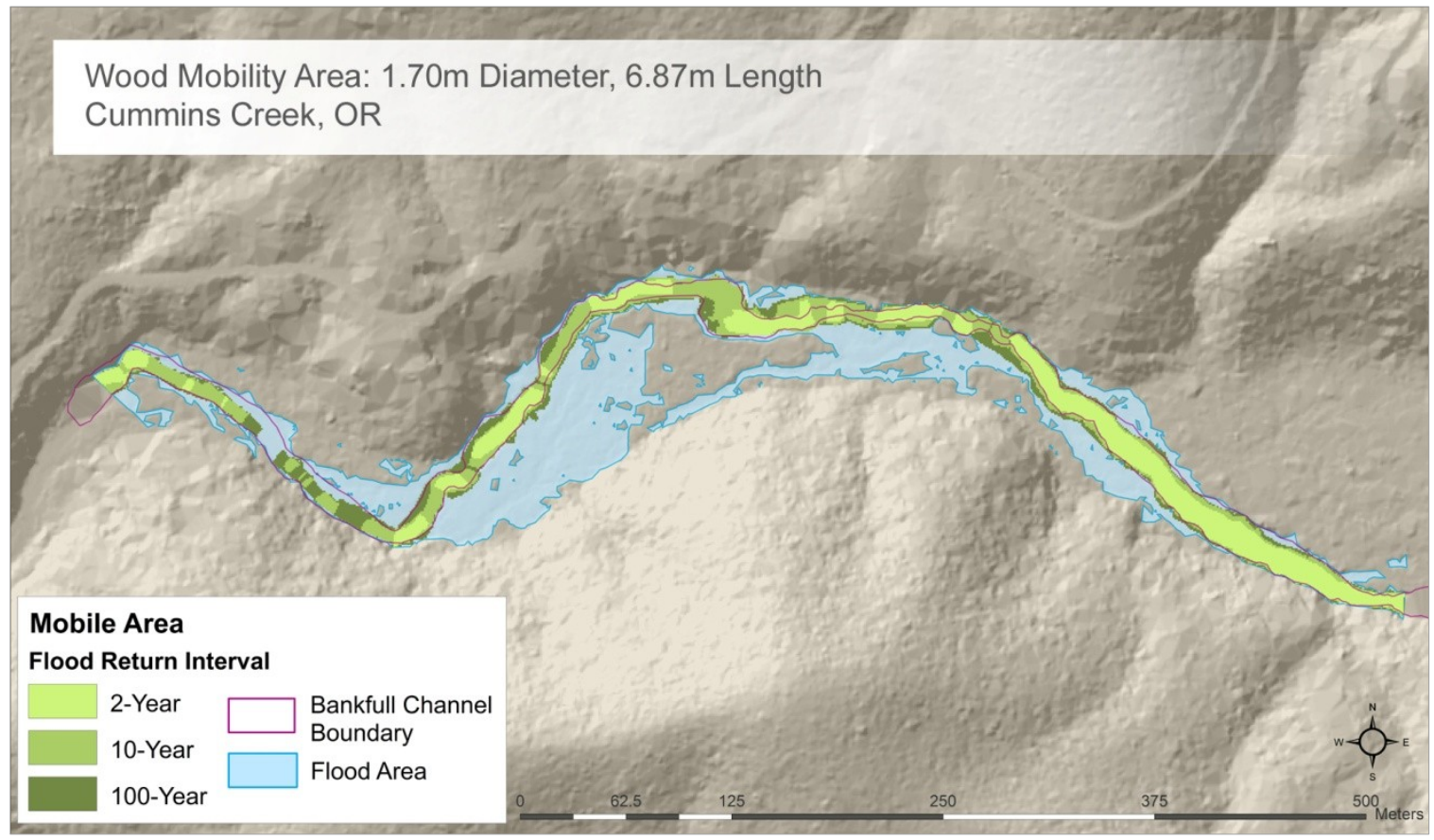

Figure 4.24: LWD mobility map for $1.7 \mathrm{~m}$ diameter/6.87m length wood during a 2-year, 10-year, and 100-year flood. 


\section{DISCUSSION AND CONCLUSIONS}

\section{Research Significance}

My research builds upon recent flume experiments that predict LWD mobility (Bocchiola et al., 2006a; Braudrick and Grant, 2000). While the flume experiments can explain wood mobility in terms of the myriad variables within mechanistic equations (4), they are unable to predict where exactly wood might move in a particular stream. My GIS model advances the flume experiments by its ability to solve the flume-tested mechanistic equation (3) in 2-dimensional space, accounting for the spatial variability of the variables leading to wood mobility. The final results are a series of maps illustrating predicted areas of LWD mobility for specific sizes of wood. This approach is different from Curran (2010), who used the flume equation models to predict jam spacing and wood transport distance in the San Antonio River, Texas based on wood attributes, channel characteristics, and discharge. Although she applied the model to a real-world river, channel characteristics were described with representative values, and the results were not tied into geographic space.

There are a variety of techniques that have been used to examine wood mobility in streams (MacVicar et al., 2009). These techniques range from conducting field surveys (Lienkaemper and Swanson, 1987; Warren and Kraft, 2008), using repeat aerial photography (Marcus et al., 2002) to track the location of individual pieces of wood from year to year. Ruiz-Villanueva et al. (2012) use 
a GIS model to identify the relative importance of LWD recruitment processes, including fluvial transport, at the basin scale. However, the results of their research illustrate that despite similarities in forest composition and structure, dominant recruitment processes vary from basin to basin based on topographical differences. Despite the previous work tracking and predicting wood mobility in streams, this is the first attempt in using GIS to map possible wood mobility areas based on LWD size and discharge.

\section{LWD Survey and Spatial Model Results}

LWD survey results demonstrate that wood quantity found in Cummins Creek is similar to wood found in other streams in the Pacific Northwest region. I surveyed a total of 232 pieces of wood in a $\sim 1 \mathrm{~km}$ study reach. Previous studies have surveyed similar quantities of wood over varying stream distances. For example, May and Gresswell (2003) surveyed 34 pieces of wood per 100m in the North Fork Cherry Creek, a $3^{\text {rd }}$ order stream located in the Southern Oregon Coast Range. Likewise, a total of 305 LWD pieces were mapped in Mack Creek, a $3^{\text {rd }}$ order stream located in the Cascade Range (Lienkaemper and Swanson, 1987), and 1384 LWD pieces were surveyed along $8.4 \mathrm{~km}$ in a previous study at Cummins Creek (Reeves et al., 2003). LWD survey results demonstrate that wood sizes found in Cummins Creek are also similar to wood found in other streams in the Pacific Northwest region. LWD diameter and lengths in Cummins Creek have a reverse-J shaped distribution, with 'small' LWD $(\leq 0.4 \mathrm{~m}$ diameter or 
$\leq 6.87 \mathrm{~m}$ length) outnumbering larger diameter and lengths (Figures 4.1 and 4.2 ). This wood size distribution shape is common for LWD present in old-growth forest streams (Meleason, 2001). Therefore, based on the LWD survey results, my LWD incipient motion map results can be placed into context to other research studying LWD in the Pacific Northwest, and is relevant to other streams in the region.

The final LWD incipient motion maps illustrate that every LWD size combination used in the spatial model, with the exception of $1.7 \mathrm{~m} / 47.2 \mathrm{~m}$ LWD, is mobile in Cummins Creek (Figures 4.17-4.24). However, LWD survey results illustrate that all mobile wood in Cummins Creek have diameter and length combinations $<0.8 \mathrm{~m} / 18.4 \mathrm{~m}$. Although LWD survey results are consistent with other studies identifying wood shorter than bankfull channel width as mobile within the stream (Lienkaemper and Swanson, 1987; Nakamura and Swanson, 1994; Seo and Nakamura, 2009), my LWD survey and LWD incipient motion maps present conflicting results when considering the relationship between LWD size, stream discharge, and LWD mobility. I believe these differences result from the combination of two factors: 1) the range of naturally occurring LWD sizes, and 2) stream discharge magnitude and frequency.

Tree boles grow by adding radial mass in the form of tree-rings with height gain being a function of structural mass added to a conical base (Thomas, 2000). Branches grow similarly to tree boles, but diameter increases slower in relation to length when compared to stem growth, and branch lengths are shorter than tree 
heights (Thomas, 2000). Consequently, LWD found in Cummins Creek approaching the maximum lengths $(47.2 \mathrm{~m})$ enter as partial or whole tree boles, and must also have a large diameter. This decreases the probability of having: 1) large diameter LWD ( $\geq 1.0 \mathrm{~m})$ shorter than $47 \mathrm{~m}$, and 2$)$ long pieces of wood with a small diameter (e.g., $0.1 \mathrm{~m})$. The LWD diameter and length combinations at Cummins Creek follow this relationship: as LWD diameter increases so does length, but allowing for some longer pieces of LWD to have moderate-sized diameters (Figure 4.3). Meleason (2001) attributes LWD size distributions to LWD breakage along the length of wood into successively smaller pieces. The LWD size distributions within old-growth forest streams may also represent branch recruitment by falling directly into the stream from living trees, or by breaking off LWD that were recruited to the stream as whole trees.

I considered LWD diameter and length separately to determine wood size inputs into the spatial mobility model (Table 3.2). However, some of the modeled diameter and length combinations are not realistic when comparing these size combinations alongside LWD size distributions (Figure 5.2). Any mobility area results can be reduced to $0 \mathrm{~m}^{2}$ within the study reach for the following size combinations: $0.1 \mathrm{~m} / 47.2 \mathrm{~m}$ (Figure 4.19$), 1.7 \mathrm{~m} / 1.0 \mathrm{~m}$ (Figure 4.23 ), and 1.7/6.87m (Figure 4.24); if a LWD size combination is unrealistic, so are the spatial mobility results for that size combination. The removal of the mobility areas for these LWD size combinations reduces the inconsistencies between LWD survey and spatial mobility map results. 


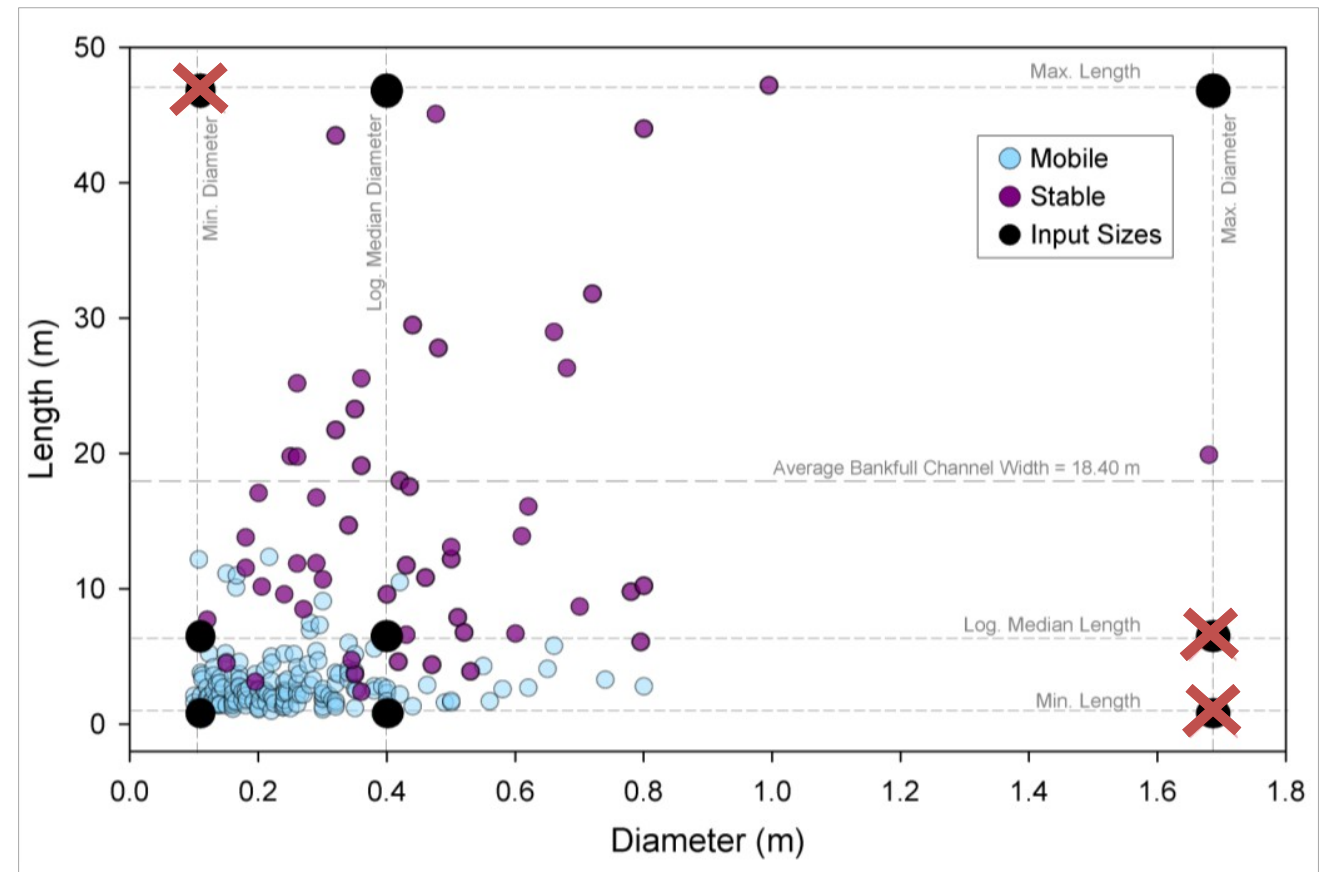

Figure 5.1: Individual LWD piece sizes with respect to the modeled size classes (black circles). Each crossed out black circle are not realistic size combinations found in Cummins Creek, and therefore would not result in realistic mobility areas in a watershed.

Discharge magnitude frequencies may further explain the remaining LWD survey size distribution results. Of the remaining modeled LWD size combinations (Figure 5.2), there are only inconsistencies between the LWD survey and spatial model results for $0.4 \mathrm{~m} / 47.2 \mathrm{~m}$ sized LWD. The spatial model results indicate that this size wood will only become mobile within a limited area of the study reach during a 100-year discharge event (Figure 4.22), allowing for only a $0.02 \%$ probability for LWD recruited in the mobility area and for a 100 -year flood to occur during any given year (Table 4.8). An assumption of the spatial model is that mobility areas illustrate where incipient motion can occur directly after the time of recruitment. Mobility probability reduces from the time of 
recruitment into the future because it is immobilized by sediment and mobile LWD that are deposited around stable wood pieces (Brummer et al., 2006; Manners and Doyle, 2008; Marston, 1982). Therefore, there is a small probability of finding $0.4 \mathrm{~m} / 47.2 \mathrm{~m}$ mobile wood sizes during LWD surveys, and could explain why there were no mobile pieces this size found in Cummins Creek.

The following wood sizes were identified as mobile in both the LWD survey and spatial model results: $0.1 \mathrm{~m} / 1.0 \mathrm{~m}$ (Figure 4.17$), 0.1 \mathrm{~m} / 6.87 \mathrm{~m}$ (Figure 4.18), $0.4 \mathrm{~m} / 1.0 \mathrm{~m}$ (Figure 4.20 ), and $0.4 \mathrm{~m} / 6.87 \mathrm{~m}$ (Figure 4.21 ). In the spatial model results, these sizes are mobile during the 2-year discharge event within the bankfull channel boundary, and mobilization areas extend into the side channels and floodplain during the 10-year and 100-year discharge events along the entire length of the study reach. The probability of these LWD sizes recruited into a 2-year mobility area and for a 2-year flood to occur during any given year are $38.30 \%$ (Table 4.3), 34.89\% (Table 4.4), 33.05\% (Table 4.6), and $31.30 \%$ (Table 4.7), respectively. The alternative of the spatial model assumption described above is that if LWD becomes mobile shortly after recruitment, it is likely that it will remain unanchored in the channel and free to be mobilized in the future. Therefore, there is a relatively higher probability of finding small mobile wood sizes during LWD surveys, and could explain why there were all mobile pieces found in Cummins Creek are shorter than bankfull channel width. 


\section{Potential Use of Spatially-Explicit LWD Mobility Modeling}

The spatial model results combined with the LWD survey results indicate there are no preferential locations for log-jam development within the study reach based on LWD mobility. Spatial model results indicate there are no incipient mobility areas for LWD with $1.7 \mathrm{~m}$ diameters at any length, and the probability of incipient motion occurring for $47.2 \mathrm{~m}$ length LWD at any diameter is also low. Therefore, tree boles and branches must begin to approach and exceed the maximum sizes found in Cummins Creek in order for LWD to remain stable when it is recruited into the stream. LWD approaching these sizes will remain in their original recruitment positions, becoming the key-wood foundation for future logjams and accumulations. The remaining small pieces of wood $(<0.4 \mathrm{~m}$ diameter and $<6.87 \mathrm{~m}$ length) are more likely to be mobilized during frequent 2-year flood discharge events, becoming racked wood in log-jam accumulations.

Although future research is needed to refine the LWD mobility maps, there are lessons in the LWD mobility results at Cummins Creek for land managers who use LWD as part of a stream restoration or conservation plan. The reintroduction of LWD into modified channels creates desirable habitat features such as pools (Roni et al., 2002), but may not return stream channels to undisturbed conditions (Larson et al., 2001). The flood disturbance regime is altered in an urbanized stream; high magnitude discharges that extend beyond the bankfull channel occur more frequently in urbanized streams than in natural 
streams (Booth, 1991), which leads to increased LWD mobility in urbanized streams (Keim et al., 2000). The spatial model results illustrate when LWD size is held constant, the area of LWD incipient motion increases with discharge. Therefore, the LWD mobility maps have the potential to illustrate the minimum size of stable pieces of wood based on flood disturbance regime as well as illustrating the areas where small LWD may be mobilized. When mobile LWD sizes and mobility areas are considered together, stream restoration projects using LWD could be engineered and placed in locations where LWD structures and dynamics mimic natural streams.

\section{Research Limitations}

There are potential limitations to the approach I used in my research. The results of the GIS model represent only initial mobility, and mobility areas are only applicable to wood that has just been recruited to its present location in the stream. These maps only show areas where LWD mobilization could be initiated by stream flow, and do not represent total travel distance. The mobility areas assume that there are no barriers, such as vegetation, to wood mobility. In reality, LWD is never recruited to an empty stream flowing through an old-growth forest. If LWD becomes mobile on the floodplain during the 100-year discharge, it may become blocked by trees or shrubs that are growing there (Bocchiola et al., 2006b). Likewise, log-jams that encompass the complete width of the stream 
channel are common in old-growth forest streams, blocking wood from flowing freely downstream (Abbe and Montgomery, 2003). Other studies have predicted that if wood becomes mobilized in streams with high LWD loading, it moves downstream in a congested group rather than as individual pieces of wood (Braudrick et al., 1997).

I did not validate this model by tracking individual LWD mobility because of time constraints. As my research demonstrates, wood mobility is a stochastic process in time and space, and would take many years of repetitive surveys to validate these maps. I created the water depth, velocity, and slope layers from the modified-LiDAR DEM. Any errors in the bathymetry interpolation would propogate through the modeling process and lead to errors in the final mobility visualization. It is possible that the differences between the LWD results and the mobility visualization result from such errors or misrepresentation of channel bathymetry (Appendix A). Nevertheless, this research represents an important first step toward modeling actual wood mobility as a function of recruitment method, size, and discharge, and as such, can be a useful tool for better understanding LWD dynamics in natural streams.

\section{Future Research}

I can recommend a few future research avenues resulting from this research. First, LWD mobility maps should be refined to represent conditions 
closer to true conditions because of the maps' potential usefulness. This includes accounting for the hydraulics of channel spanning log-jams (Manners et al., 2007) and transport in the presence of obstacles (Bocchiola et al., 2006b; Faustini and Jones, 2003). Additionally, there is a need to model more wood sizes to determine the critical log size at which wood becomes mobile during any given discharge.

If similar maps were created for other streams where long-term tracking of LWD is already taking place, these site-specific observations could refine mobility areas or relationships between LWD size and discharge. I think it would also be interesting to compare how mobility areas are different when they are based on different equations, such as site specific regression equations (Merten et al., 2010; Wohl and Jaeger, 2009). The equation used in the GIS model has other variables that I did not consider manipulating, such as wood density and the drag coefficient. A sensitivity analysis is needed to determine the effect of any one variable in determining LWD mobility areas. Nevertheless, this study demonstrates that it is possible to model the incipient motion of LWD, which moving forward, should become an integral step in any LWD analysis. 


\section{REFERENCES}

Abbe, T.B., Montgomery, D.R., 1996. Large woody debris jams, channel hydraulics and habitat formation in large rivers. Regulated Rivers: Research \& Management, 12(2-3), 201-221.

Abbe, T.B., Montgomery, D.R., 2003. Patterns and processes of wood debris accumulation in the Queets river basin, Washington. Geomorphology, 51(1-3), 81-107.

Bahuguna, D., Mitchell, S.J., Miquelajauregui, Y., 2010. Windthrow and recruitment of large woody debris in riparian stands. Forest Ecology and Management, 259(10), 2048-2055.

Beechie, T.J., Pess, G., Kennard, P., Bilby, R.E., Bolton, S., 2000. Modeling Recovery Rates and Pathways for Woody Debris Recruitment in Northwestern Washington Streams. North American Journal of Fisheries Management, 20(2), 436-452.

Benda, L., Hassan, M.A., Church, M., May, C.L., 2005. Geomorphology of steepland headwaters: The transition from hillslopes to channels. JAWRA Journal of the American Water Resources Association, 41(4), 835-851.

Benda, L., Miller, D., Andras, K., Bigelow, P., Reeves, G., Michael, D., 2007. NetMap: A New Tool in Support of Watershed Science and Resource Management. Forest Science, 53(2), 206-219.

Benda, L., Miller, D., Sias, J., Martin, D., Bilby, R., Veldhuisen, C., Dunne, T., 2003. Wood recruitment processes and wood budgeting. In: S.V. Gregory, K.L. Boyer, A.M. Gurnell (Eds.), The ecology and management of world rivers. American Fisheries Society, Symposium 37. American Fisheries Society, Bethesda, MD, pp. 25.

Berg, N., Carlson, A., Azuma, D., 1998. Function and dynamics of woody debris in stream reaches in the central Sierra Nevada, California. Canadian Journal of Fisheries and Aquatic Sciences, 55(8), 1807-1820.

Bocchiola, D., Rulli, M.C., Rosso, R., 2006a. Flume experiments on wood entrainment in rivers. Advances in Water Resources, 29(8), 1182-1195.

Bocchiola, D., Rulli, M.C., Rosso, R., 2006b. Transport of large woody debris in the presence of obstacles. Geomorphology, 76(1-2), 166-178.

Booth, D.B., 1991. Urbanization and the natural drainage system - Impacts, solutions, and prognoses. The Northwest Environmental Journal, 7(1), 26. 
Braudrick, C.A., Grant, G.E., 2000. When do logs move in rivers? Water Resour. Res., 36(2), 571-583.

Braudrick, C.A., Grant, G.E., Ishikawa, Y., Ikeda, H., 1997. Dynamics of Wood Transport in Streams: A Flume Experiment. Earth Surface Processes and Landforms, 22(7), 669-683.

Brummer, C.J., Abbe, T.B., Sampson, J.R., Montgomery, D.R., 2006. Influence of vertical channel change associated with wood accumulations on delineating channel migration zones, Washington, USA. Geomorphology, 80(3-4), 295-309.

Chang, H., Lafrenz, M., Jung, I.-W., Figliozzi, M., Platman, D., Pederson, C., 2010. Potential Impacts of Climate Change on Flood-Induced Travel Disruptions: A Case Study of Portland, Oregon, USA. Annals of the Association of American Geographers, 100(4), 938-952.

Collins, B.D., Montgomery, D.R., Fetherston, K.L., Abbe, T.B., 2012. The floodplain large-wood cycle hypothesis: A mechanism for the physical and biotic structuring of temperate forested alluvial valleys in the North Pacific coastal ecoregion. Geomorphology, 139-140, 460-470.

Cooper, R.M., 2005. Estimation of peak discharges for rural, unregulated streams in western Oregon. U.S. Dept. of the Interior, U.S. Geological Survey, Reston, Va.

Curran, J.C., 2010. Mobility of large woody debris (LWD) jams in a low gradient channel. Geomorphology, 116(3-4), 320-329.

Dilts, T., 2011. Polygon to Centerline Tool for ArcGIS. Great Basin Ecology Lab Website Download, Reno, NV.

ESRI, 2009. World Shaded Relief, Redlands, CA.

ESRI, 2011. Light Grey Canvas Base Map, Redlands, CA.

Faustini, J.M., Jones, J.A., 2003. Influence of large woody debris on channel morphology and dynamics in steep, boulder-rich mountain streams, western Cascades, Oregon. Geomorphology, 51(1-3), 187-205.

Fetherston, K.L., Naiman, R.J., Bilby, R.E., 1995. Large woody debris, physical process, and riparian forest development in montane river networks of the Pacific Northwest. Geomorphology, 13(1-4), 133-144.

Franklin, J.F., Dyrness, C.T., 1988. Natural vegetation of Oregon and Washington. Oregon State University Press, [Corvallis?]. 
Fremier, A.K., Seo, J.I., Nakamura, F., 2010. Watershed controls on the export of large wood from stream corridors. Geomorphology, 117(1-2), 33-43.

Gessese, A.F., Sellier, M., Van Houten, E., Smart, G., 2011. Reconstruction of river bed topography from free surface data using a direct numerical approach in one-dimensional shallow water flow. Inverse Problems, 27(2), 025001.

Gurnell, A.M., Piegay, H., Swanson, F.J., Gregory, S.V., 2002. Large wood and fluvial processes. Freshwater Biology, 47(4), 601-619.

Harrelson, C.C., Rawlins, C.L., Potyondy, J.P., Rocky Mountain, F., Range Experiment, S., 1994. Stream channel reference sites an illustrated guide to field technique. U.S. Dept. of Agriculture, Forest Service, Rocky Mountain Forest and Range Experiment Station, Fort Collins, Colo. (240 W. Prospect Rd., Ft. Collins 80526).

Hilldale, R.C., Raff, D., 2008. Assessing the ability of airborne LiDAR to map river bathymetry. Earth Surface Processes and Landforms, 33(5), 773-783.

Hjulstrom, F., 1935. Studies of the morphological activity of rivers as illustrated by the River Fyris. Uppsala, Almqvist \& Wiksells.

Keim, F., Skaugset, E., Bateman, S., 2000. Dynamics of Coarse Woody Debris Placed in Three Oregon Streams. Forest Science, 46(1), 13-22.

Keller, E.A., Swanson, F.J., 1979. Effects of large organic material on channel form and fluvial processes. Earth Surface Processes, 4(4), 361-380.

Kennedy, R.S.H., Spies, T.A., 2004. Forest cover changes in the Oregon Coast Range from 1939 to 1993. Forest Ecology and Management, 200(1-3), 129-147.

Knapp, P.A., Hadley, K.S., 2012. A 300-year history of Pacific Northwest windstorms inferred from tree rings. Global and Planetary Change, 9293(0), 257-266.

Larson, M.G., Booth, D.B., Morley, S.A., 2001. Effectiveness of large woody debris in stream rehabilitation projects in urban basins. Ecological Engineering, 18(2), 211-226.

Lehner, B., Verdin, K., Jarvis, A., 2008. New global hydrography derived from spaceborne elevation data, Eos, Transactions. AGU, pp. 93-94.

Leopold, L.B., Maddock, T., 1953. The hydraulic geometry of stream channels and some physiographic implications. U.S. Govt. Print. Off., Washington. 
Li, J., Wong, D.W.S., 2010. Effects of DEM sources on hydrologic applications. Computers, Environment and Urban Systems, 34(3), 251-261.

Lienkaemper, G.W., Swanson, F.J., 1987. Dynamics of large woody debris in streams in old-growth Douglas-fir forests. Canadian Journal of Forest Research, 17(2), 150-156.

MacVicar, B.J., PiÃ@gay, H., Henderson, A., Comiti, F., Oberlin, C., Pecorari, E., 2009. Quantifying the temporal dynamics of wood in large rivers: field trials of wood surveying, dating, tracking, and monitoring techniques. Earth Surface Processes and Landforms, 34(15), 2031-2046.

Manners, R.B., Doyle, M.W., 2008. A mechanistic model of woody debris jam evolution and its application to wood-based restoration and management. River Research and Applications, 24(8), 1104-1123.

Manners, R.B., Doyle, M.W., Small, M.J., 2007. Structure and hydraulics of natural woody debris jams. Water Resources Research, 43(6).

Marcus, W.A., Marston, R.A., Colvard Jr, C.R., Gray, R.D., 2002. Mapping the spatial and temporal distributions of woody debris in streams of the Greater Yellowstone Ecosystem, USA. Geomorphology, 44(3-4), 323335.

Marston, R.A., 1982. The Geomorphic Significance of Log Steps in Forest Streams1. Annals of the Association of American Geographers, 72(1), 99108.

May, C.L., Gresswell, R.E., 2003. Large wood recruitment and redistribution in headwater streams in the southern Oregon Coast Range, U.S.A. Canadian Journal of Forest Research, 33(8), 1352-1362.

May, C.L., Gresswell, R.E., 2004. Spatial and temporal patterns of debris-flow deposition in the Oregon Coast Range, USA. Geomorphology, 57(3-4), 135-149.

Meleason, M.A., 2001. A simulation model of wood dynamics in Pacific Northwest streams. Doctor of Philosophy Dissertation, Oregon State University, Corvallis, Oregon, 158 pp.

Meleason, M.A., Gregory, S.V., Bolte, J.P., 2003. Implications of riparian management strategies on wood in streams of the Pacific Northwest. Ecological Applications, 13(5), 1212-1221. 
Merten, E., Finlay, J., Johnson, L., Newman, R., Stefan, H., Vondracek, B., 2010. Factors influencing wood mobilization in streams. Water Resources Research, 46(10).

Merwade, V., Cook, A., Coonrod, J., 2008. GIS techniques for creating river terrain models for hydrodynamic modeling and flood inundation mapping. Environmental Modelling \& Software, 23(10-11), 1300-1311.

Montgomery, D.R., 1999. Process domains and the river continuum. JAWRA Journal of the American Water Resources Association, 35(2), 397-410.

Montgomery, D.R., Beamer, E.M., Pess, G.R., Quinn, T.P., 1999. Channel type and salmonid spawning distribution and abundance. Canadian Journal of Fisheries and Aquatic Sciences, 56(3), 377-387.

Naiman, R.J., Bilby, R.E., Bisson, P.A., 2000. Riparian Ecology and Management in the Pacific Coastal Rain Forest. BioScience, 50(11), 996-1011.

Nakamura, F., Swanson, F.J., 1994. Distribution of coarse woody debris in a mountain stream, western Cascade Range, Oregon. Canadian Journal of Forest Research, 24(12), 2395-2403.

Ohmann, J.L., Gregory, M.J., Spies, T.A., 2007. Influence of environment, disturbance, and ownership on forest vegetation of coastal Oregon. Ecological Applications, 17(1), 18-33.

Read, W., 2008. The Storm King. Some historical weather events in the Pacific Northwest. Office of the Washington State Climatologist

Reeves, G.H., Burnett, K.M., McGarry, E.V., 2003. Sources of large wood in the main stem of a fourth-order watershed in coastal Oregon. Canadian Journal of Forest Research, 33(8), 1363-1370.

Roni, P., Beechie, T.J., Bilby, R.E., Leonetti, F.E., Pollock, M.M., Pess, G.R., 2002. A Review of Stream Restoration Techniques and a Hierarchical Strategy for Prioritizing Restoration in Pacific Northwest Watersheds. North American Journal of Fisheries Management, 22(1), 1-20.

Ruiz-Villanueva, V., Díez-Herrero, A., Ballesteros, J.A., Bodoque, J.M., 2012. Potential large woody debris recruitment due to landslides, bank erosion and floods in mountain basins: A quantitative estimation approach. River Research and Applications.

Seo, J.I., Nakamura, F., 2009. Scale-dependent controls upon the fluvial export of large wood from river catchments. Earth Surface Processes and Landforms, 34(6), 786-800. 
Spies, T.A., Hibbs, D.E., Ohmann, J.L., Reeves, G.H., Pabst, R.J., Swanson, F.J., Whitlock, C., Jones, J.A., Wemple, B.C., Parendes, L.A., Schrader, B.A., 2002. The Ecological Basis of Forest Ecosystem Management in the Oregon Coast Range, Forest and stream management in the Oregon coast range. Oregon State University Press, Corvallis, Or., pp. 31-67.

Thomas, P., 2000. Trees : their natural history. Cambridge University Press, Cambridge, U.K.; New York.

TomTom, International, BV., 2011. USA Parks. ESRI.

Warren, D.R., Kraft, C.E., 2008. Dynamics of large wood in an eastern U.S. mountain stream. Forest Ecology and Management, 256(4), 808-814.

White, P.S., Pickett, S.T.A., 1985. The Ecology of natural disturbance and patch dynamics. Academic Press, Orlando [etc.].

Wimberly, M.C., Spies, T.A., 2001. Influence of environment and disturbance on forest patterns in coastal Oregon watersheds. Ecology, 82(5), 1443-1459.

Wohl, E., Cenderelli, D.A., Dwire, K.A., Ryan-Burkett, S.E., Young, M.K., Fausch, K.D., 2010. Large in-stream wood studies: a call for common metrics. Earth Surface Processes and Landforms, 35(5), 618-625.

Wohl, E., Jaeger, K., 2009. A conceptual model for the longitudinal distribution of wood in mountain streams. Earth Surface Processes and Landforms, 34(3), 329-344.

Wu, S., Li, J., Huang, G.H., 2008. A study on DEM-derived primary topographic attributes for hydrologic applications: Sensitivity to elevation data resolution. Applied Geography, 28(3), 210-223. 


\section{APPENDIX A: VARIABLE DERIVATION PROCESSES}

\section{Channel Bathymetry Mapping}

\section{LiDAR}

Light detection and ranging (LiDAR) is a remote sensing technology that measures the elevation of features on the Earth with high precision. LiDAR data are delivered as a series of points with a single elevation value associated with each point. The most common use of LiDAR is creating high resolution $(<10 \mathrm{~m})$ digital elevation models (DEM) by interpolating between the ground point-cloud data. LiDAR-derived DEM data are increasingly integrated into GIS-based hydrologic analyses because the delineated boundaries of geomorphic features such as river networks and watersheds become more accurate as topographic resolution increases (Li and Wong, 2010; Wu et al., 2008).

I downloaded LiDAR ground points in .las format, the standardized LiDAR point cloud file format, during July 2011 from the Digital Coast Data Access Viewer (DOGAMI 2009). Watershed Sciences, Inc. collected the LiDAR data during the fall of 2009 as part of the DOGAMI North Coast Acquisition. The data were acquired with a Leica ALS50 Phase II device mounted on a Cessna Caravan 208B and an Optech 3100 laser system mounted in a Cessna Caravan 208. The settings created for both these systems were calibrated to capture an originating average pulse density $\geq 8$ points per $\mathrm{m}^{2}$. However, some surfaces 
can interfere with pulse returns, so final pulse density is generally lower than what the laser originally emitted. The final average pulse density for the Cummins Creek acquisition area is 8.61 points per $\mathrm{m}^{2}$ with a ground pulse density of .96 points per $\mathrm{m}^{2}$ (DOGAMI 2009). I used the 3D Analyst tools in ArcGIS v.10.0 (ESRI 2011) to create a triangular irregular network (TIN) elevation surface from the LiDAR point cloud that I then converted into a $1 \mathrm{~m}$-pixel resolution DEM (Figure 4.4).

\section{Stream Channel Survey}

I surveyed a total of 8 stream cross-sections (Figure A.1) and three temporary benchmarks using a Trimble Juno mapping grade GPS unit in the study reach during September 2009 and July 2011(Harrelson et al., 1994). I tied each cross-section into a horizontal datum by calculating the latitude and longitude of each left bank station using distance and azimuth measurements in reference to temporary benchmarks. I placed one cross-section at the upper and lower bounds of the study reach ( $\mathrm{A}$ and $\mathrm{I})$, and two cross-sections at approximate $50 \mathrm{~m}$ intervals downstream of the upper bound of the study reach (B and $C)$. The final four cross-sections were placed in reference to one large log jam; one $50 \mathrm{~m}$ upstream of the jam (D), one $5 \mathrm{~m}$ upstream of the jam (E), one $5 \mathrm{~m}$ downstream of the jam (F), and one $50 \mathrm{~m}$ downstream of the jam (G). I digitized one crosssection in GIS upstream of the lower bound of the study reach for hydrologic modeling purposes $(\mathrm{H})$. The placement of these cross-sections was done to create a representative sample of channel widths and depths of the study reach. 
I recorded velocity at the upper and lower bounding cross-sections using a Marsh-McBirney flow meter.

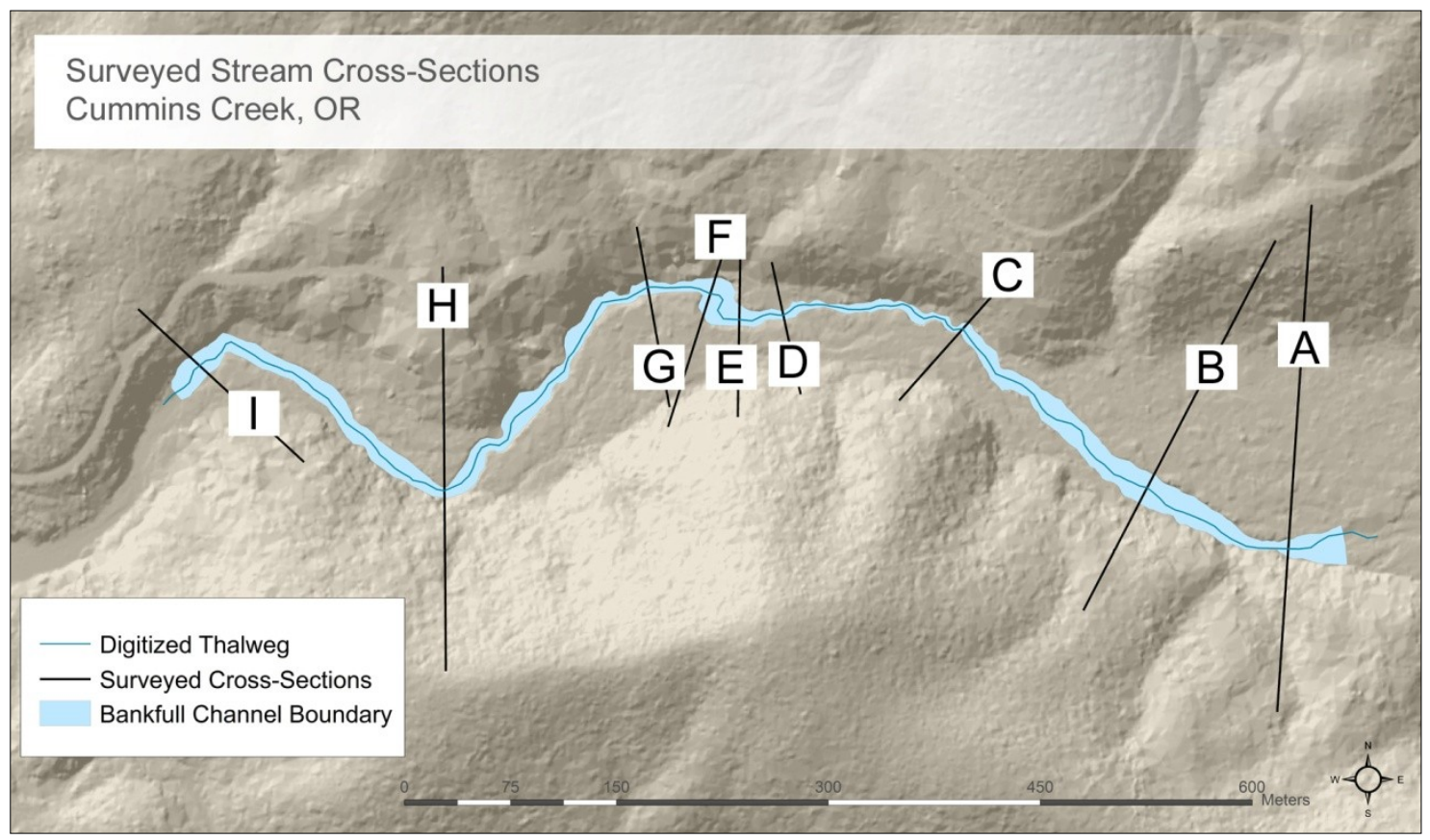

Figure A.1: Map illustrating locations of surveyed cross-sections within the study reach at Cummins Creek, OR. The bankfull channel boundary and digitized thalweg has been included to illustrate the cross-section in relation to the stream. Each cross-section is lettered and described in the text. Cross-section lines were extended for hydrologic modeling purposes.

\section{Bathymetry Interpolation}

Channel bathymetry was interpolated in ArcGIS v9.3.1 (ESRI 2009) using a custom GIS tool created for hydrologic terrain modeling (Merwade et al., 2008). While interpolation is a common tool within GIS computer systems, these tools do not allow for river flow direction and anisotropy, which are important principles in hydrologic modeling (Merwade 2008). The custom GIS tool is necessary 
because it considers these principles when interpolating between cross-section elevation data.

The custom tool requires three geographic data input layers in order to interpolate channel bathymetry. These inputs are a channel boundary layer which is equivalent to the bankfull channel, a channel centerline, and georeferenced cross-sections with latitude, longitude, and elevation data associated with them. I digitized the channel boundary and centerline GIS layers using the LiDAR-derived DEM as the reference topography (Figure 4.4). I created the 3D cross-sections from the data recorded during the stream channel cross-section surveys. Each data collection point along the cross-section survey was converted to a point with latitude and longitude in geographic coordinate space using distance and azimuth calculations. I added these x,y point locations with the associated surveyed elevation data as vertices within the GIS feature layer representing cross-section lines (Figure A.2). 


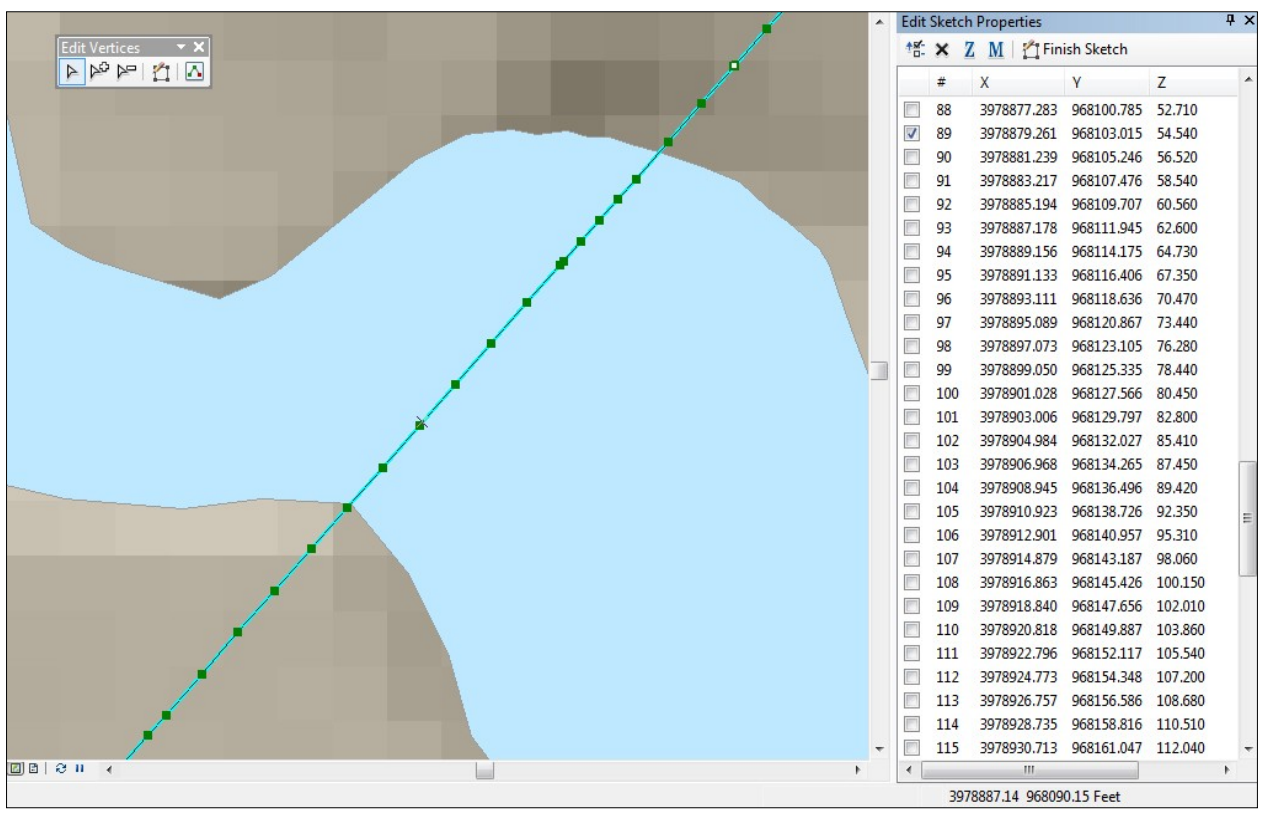

Figure A.2: Screenshot of ArcGIS editing process to create cross-section lines with survey data.

The output of the custom GIS tool is a 3D line mesh (Figure A.3). The mesh line density is determined by user input values into the tool interface.

Users control the number of lines interpolated within the channel boundary, both running parallel (profile lines) and perpendicular (cross-section lines) to streamflow. The spacing between profile lines is determined by the average channel width, while the number of cross-section lines is arbitrary based on the user's needs. I listed the input parameters as $28 \mathrm{~m}$ average channel width, 25 profile lines, and $1 \mathrm{~m}$ cross-section spacing. 


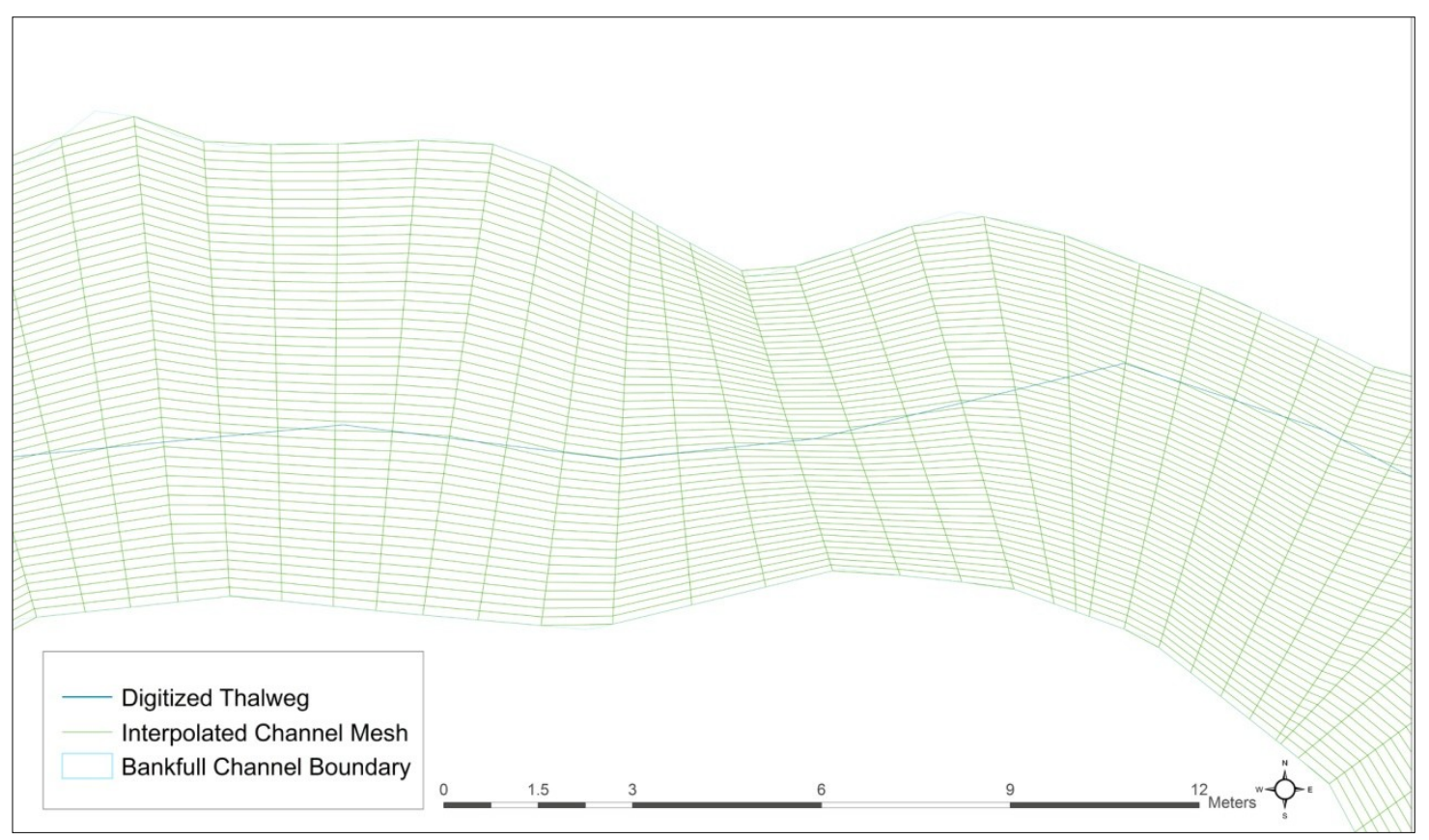

Figure A.3: 2-Dimensional image of channel bathymetry mesh.

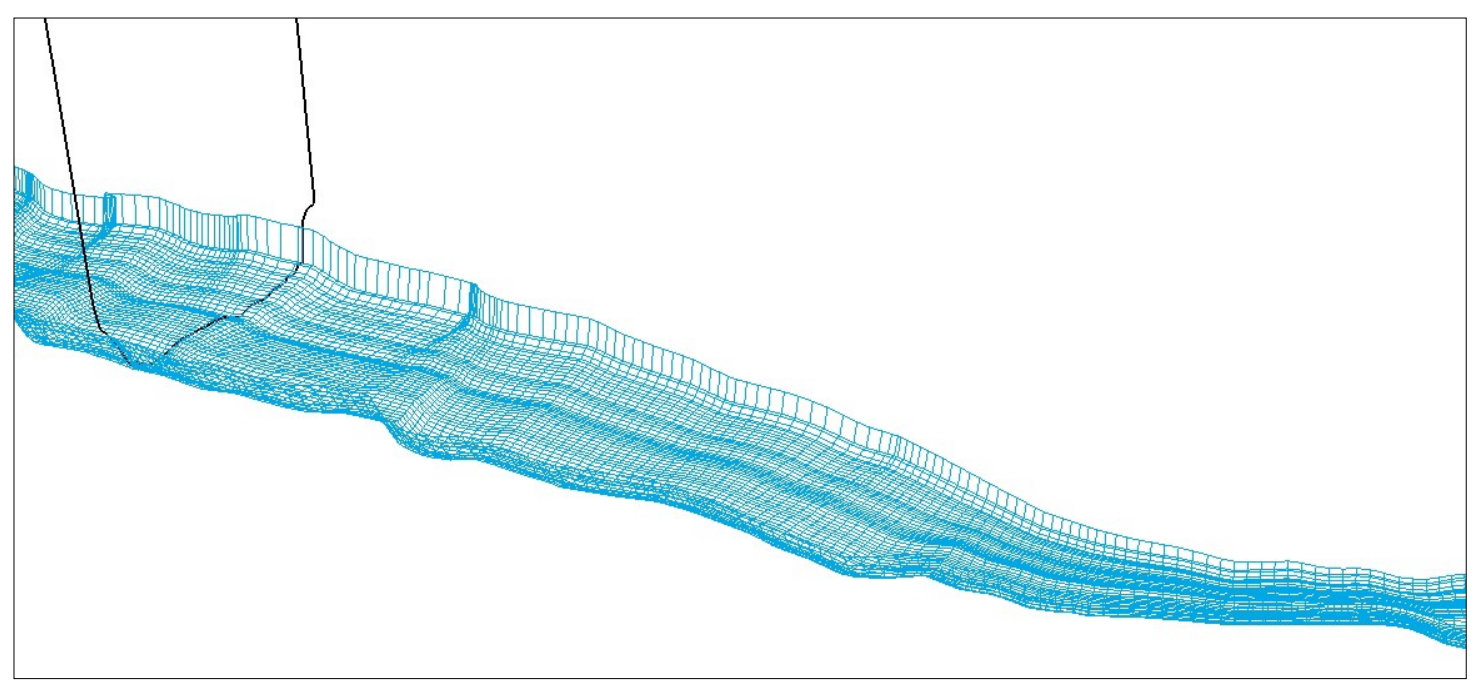

Figure A.4: 3-Dimensional rendering of the interpolated channel bathymetry mesh. The black line is a surveyed cross-section line. Elevations are vertical exaggerated by $5 x$. 


\section{LiDAR/Bathymetry Integration}

I created two elevation layers; a LiDAR-derived DEM (Figure 4.2) and a line mesh representing channel bathymetry (Figure A.4). I then created a continuous surface between hillslopes and channel bathymetry to integrate the river bathymetry with the original LiDAR data. In its original form, the 3D line mesh output is not compatible with the LiDAR point cloud. However, the line mesh has 3D vertices where the profile lines and cross-section lines intersect where each vertex contains $x, y, z$ coordinate information.

In ArcGIS v.9.3.1, I converted the vertices into a 3D point feature class (Figure A.5). The 3D point feature class representing the vertices of the line mesh is compatible for integration into the LiDAR point cloud. First, I removed the LiDAR points within the channel from the LiDAR point cloud using the 'Erase' tool. I then used the 'Merge' tool to insert the new vertex point layer into the LiDAR point cloud (Figure A.6). I consider this new point file as my modified LiDAR point cloud. From this modified point cloud, I created a modified LiDARderived DEM following the same steps as creating the original DEM. This modified LiDAR-derived DEM data are input elevation values for flood inundation and velocity mapping.

The accuracy of this process is limited by the number of surveyed crosssections. As a stream becomes more complex, more cross-sections are necessary to represent this complexity in the final interpolation. This is especially 
true if the complexity is caused by log-jams, which can alter channel form in short distances (Abbe and Montgomery, 2003). One method to improve the interpolation is adding cross-section surveys just upstream and downstream of every channel-spanning log-jam that is in the stream in addition to regularly spaced cross-sections.

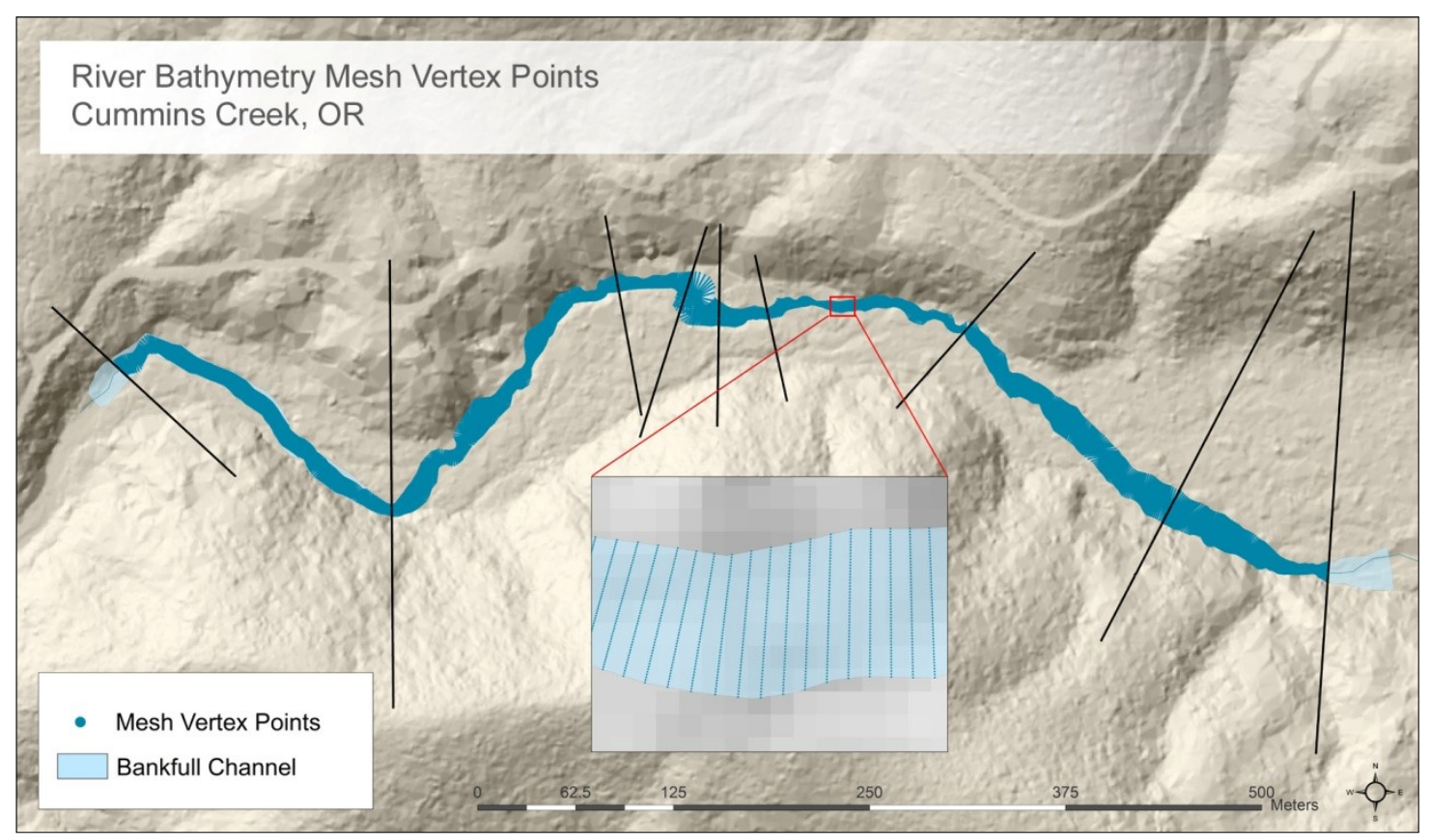

Figure A.5: Map illustrating the point feature class representing the line mesh vertices. Inset map shows detail. 


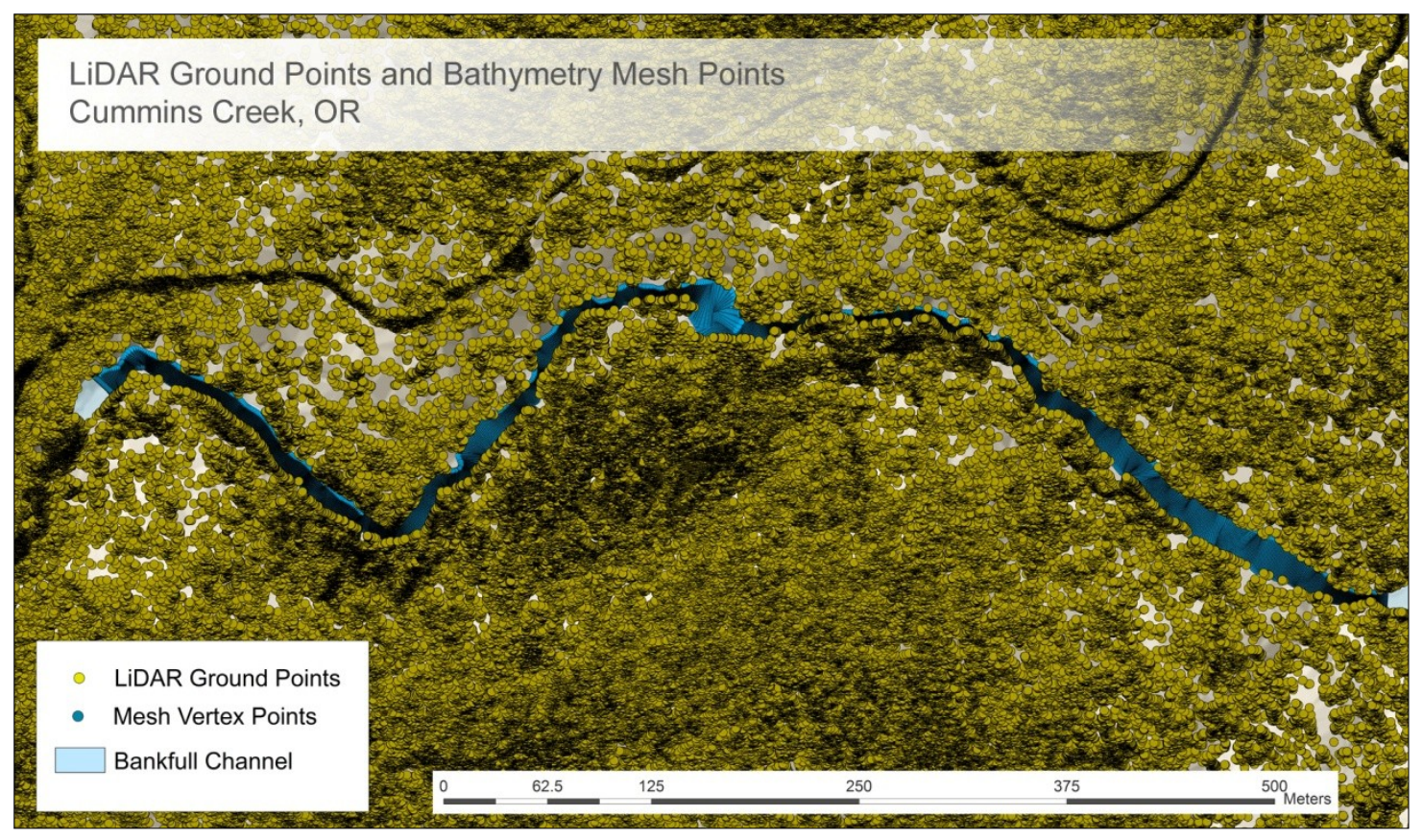

Figure A.6: Map illustrating the different coverage areas of LiDAR ground points versus line mesh vertex points.

\section{Flood and Velocity Analysis}

\section{Model Preprocessing}

HEC-GeoRAS I digitized four inputs in HEC-GeoRAS: the stream centerline, bank lines, cross-sections, and flow paths from the layers created in the LiDAR modification process. I digitized one additional cross-section lacking survey data to allow the calculation of flood inundation depths and flood areas for a portion of the study reach (Line H, Figure A.1). I converted these twodimensional layers into three-dimensional features using elevation data associated with the $1 \mathrm{~m}$ resolution modified LiDAR-derived DEM (Figure A.7). 
HEC-RAS I imported all data generated with HEC-GeoRAS into HECRAS. I then inspected each cross-section for accuracy with respect to field survey data. Comparison of bathymetry data generated by HEC-GeoRAS from the modified LiDAR-derived DEM revealed that channel bathymetry interpolation results were similar but not exact to surveyed values. These minor differences were deemed unlikely to affect my accuracy assessment and appear to reflect the statistical estimation of the DEM bathymetry values rather than a true surface.

I substituted the interpolated elevation data for field observed values for each cross-section, beginning where the first DEM elevation matched the elevation of cross-section's left stake and ending with the DEM elevation value that matched the cross-section's right stake elevation value. The remaining values in the DEM-derived cross-section lacking survey data remained unchanged. The reason I substituted surveyed bathymetry for DEM-derived data is because true data values are necessary to validate the modeled water surface elevations with surveyed water surface elevations. I accepted the elevation data that HEC-GeoRAS generated for the digitized cross-section line 'H' (Figure A.1) because I did not have comparable survey data. 


\section{Flood Inundation and Velocity Mapping}

I completed my HEC-RAS steady flow analysis using peak-flow discharge values generated by the US Geological Survey's Oregon StreamStats website (2011) for the 2, 10, and 100-year floods as well as the surveyed discharge value observed during July 2011 for HEC-RAS water depth validation (Table 3.4). The USGS modeled peak-flow discharge values are estimated for non-gaged stations using regression equations formulated from gaged stations in the same region (Cooper, 2005). I assigned Manning's $n$ roughness values to the channel and floodplains based on conditions observed during the stream channel survey. Manning's $\mathrm{n}$ values approached maximum typical values (US Army Corps of Engineers, 2002) because of the dense riparian forest, high loadings of terrestrial coarse woody debris, and inline log-jam structures (Figures 2.4-2.9) within the study reach.

I exported water surface elevation and velocity results from the steady flow analysis in HEC-RAS and imported these data into HEC-GeoRAS for mapping. In this manner, water depth $\left(d_{w}\right)$ and velocity $(U)$ are determined for the entire study reach and further used for modeling wood mobility. 


\section{APPENDIX B: ARCGIS MODELBUILDER SCHEMATICS}

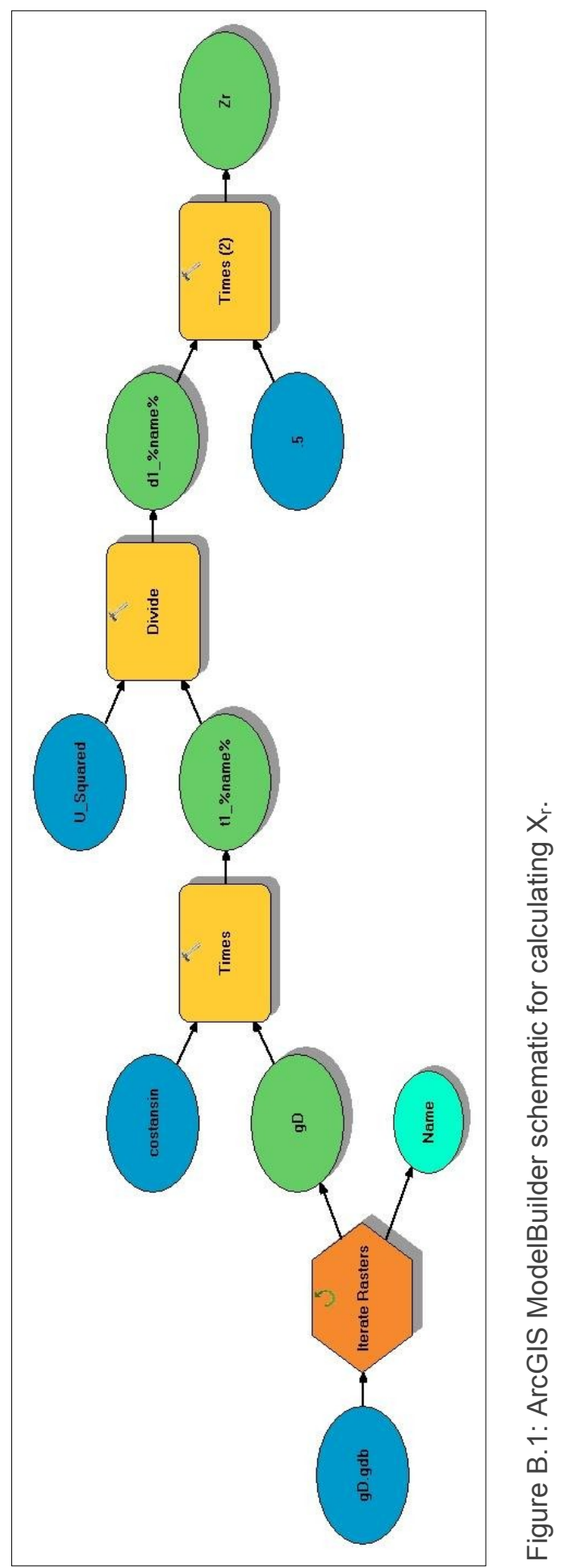




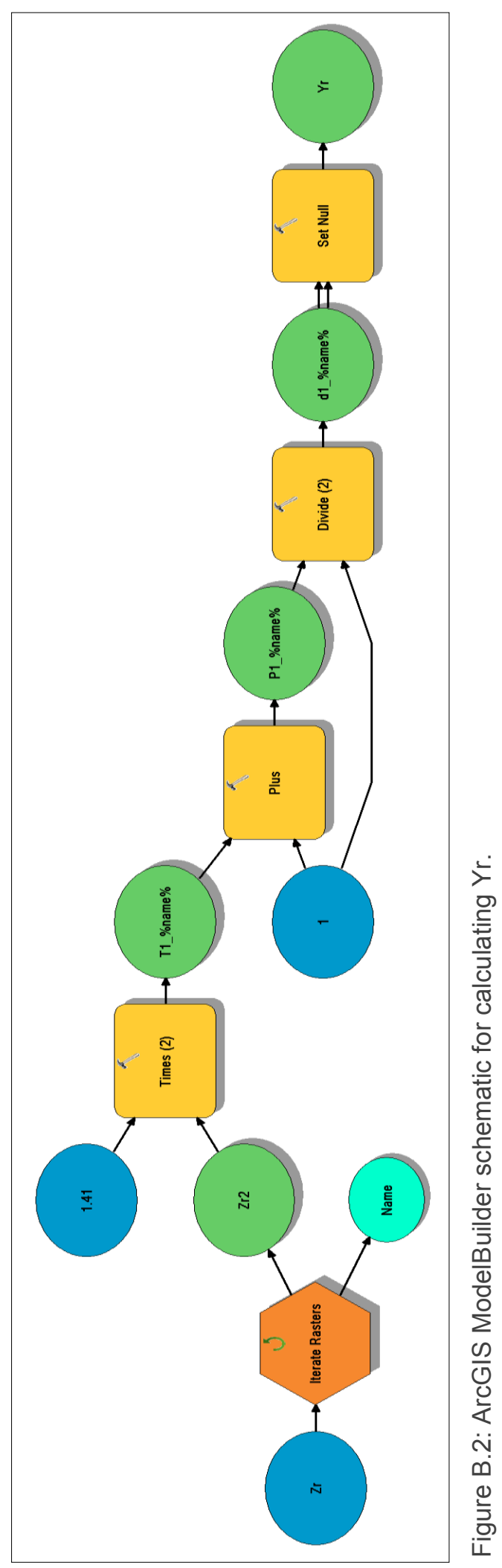




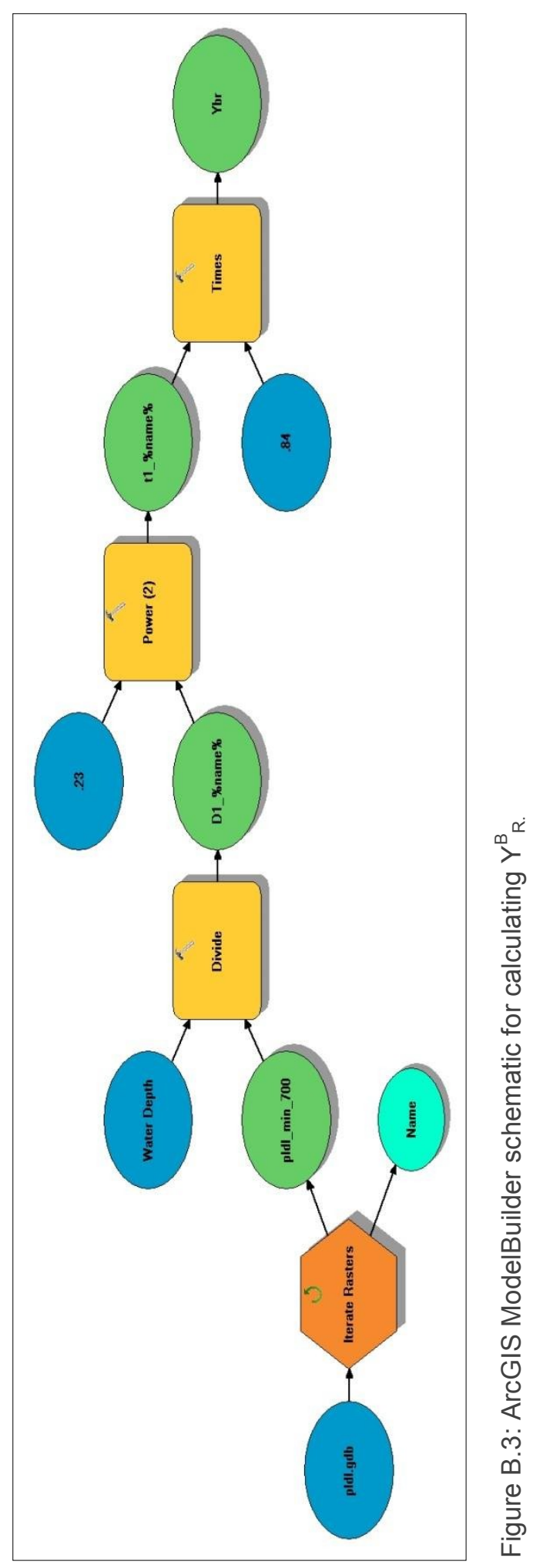

